Prepared in cooperation with the National Park Service

\title{
Groundwater Flow, Quality (2007-10), and Mixing in the Wind Cave National Park Area, South Dakota
}

Scientific Investigations Report 2011-5235

U.S. Department of the Interior U.S. Geological Survey 
Front cover. Fluorescein dye in Wind Cave in Windy City Lake, a lake that merged with Calcite Lake before the end of 1999. Dye was injected by National Park Service staff into What the Hell Lake in February 2008 and was detected in Windy City Lake 2 months later. This photograph was taken November 2008 by Peter Sprouse, National Park Service.

Back cover. Upper left: Measuring the physical properties of water from Stairway Spring. Upper right: Leading us to the water in Wind Cave! Photograph by Jason Walz, National Park Service. Lower left: Squeezing through a narrow place above What the Hell Lake in Wind Cave. Photograph by Jason Walz, National Park Service.

Lower right: Downloading temperature data collected from Highland Creek. Photograph by Jason Walz, National Park Service. 


\section{Groundwater Flow, Quality (2007-10), and Mixing in the Wind Cave National Park Area, South Dakota}

By Andrew J. Long, Marc J. Ohms, and Jonathan D.R.G. McKaskey

Prepared in cooperation with the National Park Service

Scientific Investigations Report 2011-5235 


\title{
U.S. Department of the Interior \\ KEN SALAZAR, Secretary \\ U.S. Geological Survey \\ Marcia K. McNutt, Director
}

\author{
U.S. Geological Survey, Reston, Virginia: 2012
}

For more information on the USGS - the Federal source for science about the Earth, its natural and living resources, natural hazards, and the environment, visit http://www.usgs.gov or call 1-888-ASK-USGS.

For an overview of USGS information products, including maps, imagery, and publications, visit http://www.usgs.gov/pubprod

To order this and other USGS information products, visit http://store.usgs.gov

Any use of trade, product, or firm names is for descriptive purposes only and does not imply endorsement by the U.S. Government.

Although this report is in the public domain, permission must be secured from the individual copyright owners to reproduce any copyrighted materials contained within this report.

Suggested citation:

Long, A.J., Ohms, M.J., McKaskey, J.D.R.G., 2012, Groundwater flow, quality (2007-10), and mixing in the Wind Cave National Park area, South Dakota: U.S. Geological Survey Scientific Investigations Report 2011-5235, 50 p. 


\section{Acknowledgments}

The authors would like to thank Jennifer Back, Jeff Hughes, Jason Walz, and Steve Schrempp of the National Park Service for assistance in sample collection. Jennifer Back assisted in planning the study and making other helpful suggestions for data collection and interpretation.

Joel Petersen of the U.S. Geological Survey assisted in installing water-level transducers and data loggers for wells. 


\section{Contents}

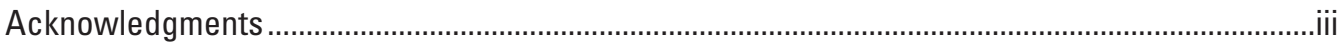

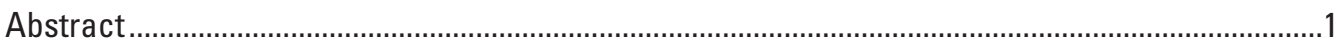

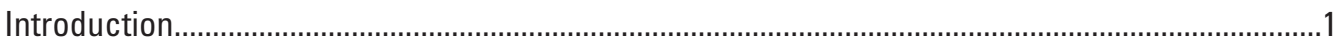

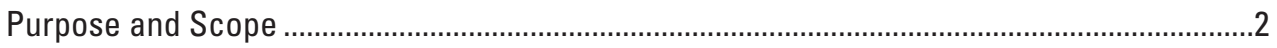

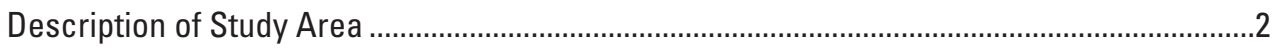

Methods

Sample Collection and Hydrochemical Data .....................................................................

Principal Component and Cluster Analyses .............................................................................11

End-Member Mixing ........................................................................................................11

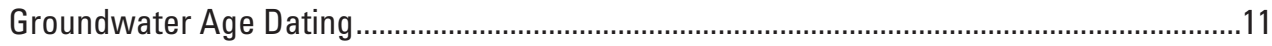

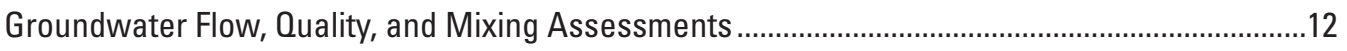

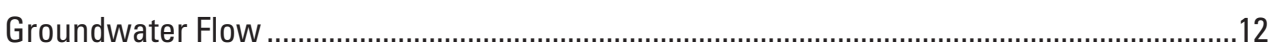

Groundwater Gradients and Flow Directions ………...............................................12

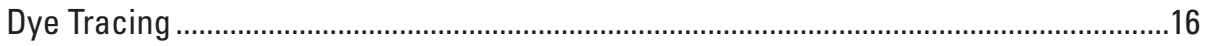

Groundwater Quality ..................................................................................................

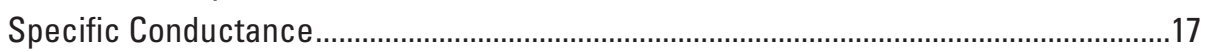

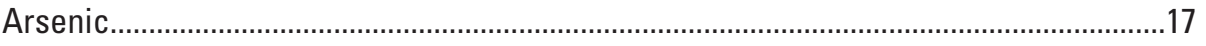

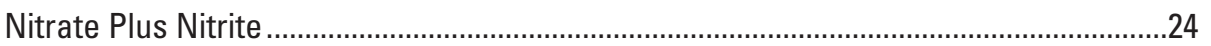

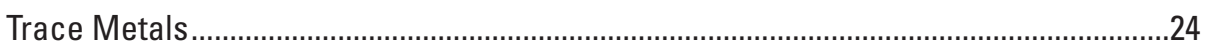

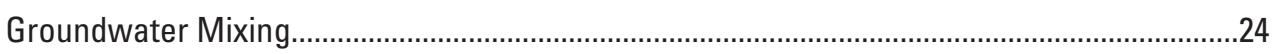

Principal Component and Cluster Analyses ..................................................................26

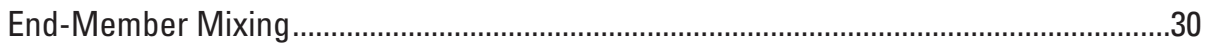

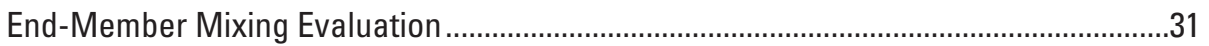

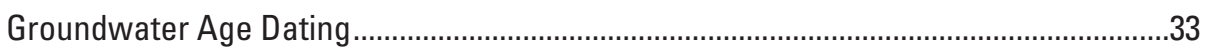

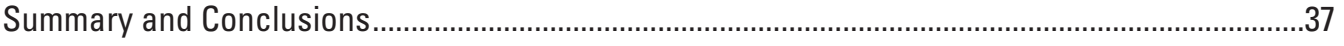

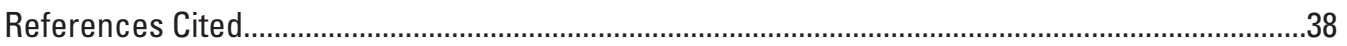

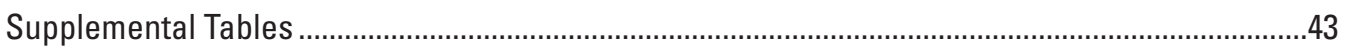

\section{Figures}

1. Map of study area showing hydrogeologic units and potentiometric surface of the Madison aquifer

2. Map showing mapped passages of Wind Cave and sampled sites shown in plan view and as a generalized hydrogeologic cross-section projected onto a single vertical plane..

3. Graph showing chlorofluorocarbon and tritium concentrations in the

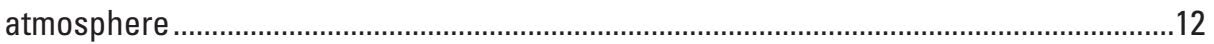

4. Map showing potentiometric surface of the Minnelusa aquifer....................................13

5. Graph showing water-level hydrographs for Windy City Lake (site WCL) and well Md7-11 
6. Map showing difference in hydraulic head between the Madison and Minnelusa aquifers..

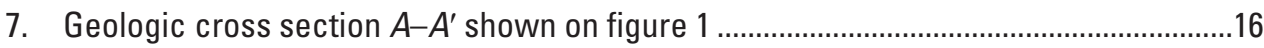

8. Map showing geospatial distribution of specific conductance for the Minnelusa, Madison, and Precambrian aquifers in the study area...

9. Map showing geospatial distribution of arsenic concentrations for the Minnelusa, Madison, and Precambrian aquifers in the study area..

10. Boxplots of arsenic concentrations in the Minnelusa and Madison aquifers

11. Map showing geospatial distribution of arsenic concentrations for all groundwater and surface-water samples in and near the study area....

12. Scatter plot of arsenic concentrations in the Minnelusa aquifer and sampling depth from the top of the aquifer....

13. Map showing geospatial distribution of nitrate plus nitrite for the Minnelusa and Madison aquifers in the study area.....

14. Graph showing results of principal component analysis and cluster analysis for site-averaged data plotted on the first two principal component axes.....

15. Map showing results of cluster analysis showing the geographic locations of cluster areas.

16. Graph showing principal component analysis biplot

17. Map showing geospatial distribution of apparent groundwater ages for the Madison aquifer estimated from CFC-12.

\section{Tables}

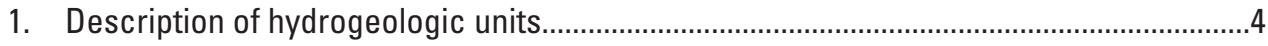

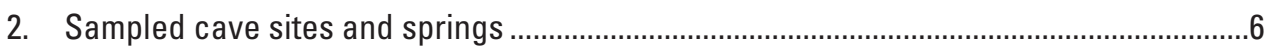

3. Water-quality sampling sites and constituents analyzed in samples...............................8

4. Chlorofluorocarbon (CFC) and tritium data....................................................................18

5. Results of laboratory analyses of the presence of fluorescein dye in charcoal dye receptors that were placed in Wind Cave water bodies and two wells

6. Trace-metal data for water samples from selected sites within

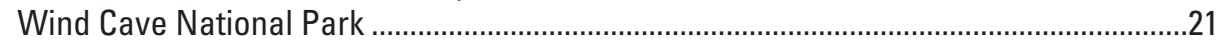

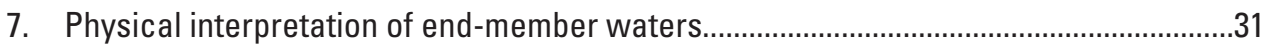

8. End-member contributions as an average to each cluster area.......................................31

9. End-member contributions for Wind Cave sites...............................................................32

10. Temperature, specific conductance, and calcium plus sulfate in

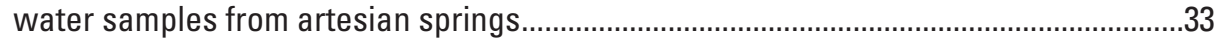

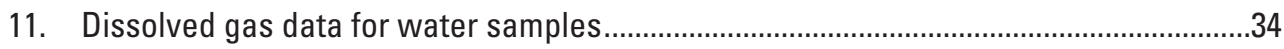

12. Hydrochemical data for water samples...........................................................................4

13. Summary of hydrochemical data for the five hydrogeologic domains............................50 


\section{Conversion Factors}

\begin{tabular}{|c|c|c|}
\hline Multiply & By & To obtain \\
\hline \multicolumn{3}{|c|}{ Length } \\
\hline meter (m) & 3.281 & foot $(\mathrm{ft})$ \\
\hline kilometer (km) & 0.6214 & mile (mi) \\
\hline \multicolumn{3}{|c|}{ Volume } \\
\hline liter (L) & 33.82 & ounce, fluid (fl. oz) \\
\hline liter $(\mathrm{L})$ & 2.113 & pint (pt) \\
\hline liter (L) & 1.057 & quart (qt) \\
\hline liter (L) & 0.2642 & gallon (gal) \\
\hline liter (L) & 61.02 & cubic inch $\left(\mathrm{in}^{3}\right)$ \\
\hline \multicolumn{3}{|c|}{ Flow rate } \\
\hline cubic meter per second $\left(\mathrm{m}^{3} / \mathrm{s}\right)$ & 35.31 & cubic foot per second $\left(\mathrm{ft}^{3} / \mathrm{s}\right)$ \\
\hline meter per day $(\mathrm{m} / \mathrm{d})$ & 3.281 & foot per day (ft/d) \\
\hline
\end{tabular}

Temperature in degrees Celsius $\left({ }^{\circ} \mathrm{C}\right)$ may be converted to degrees Fahrenheit $\left({ }^{\circ} \mathrm{F}\right)$ as follows:

$$
{ }^{\circ} \mathrm{F}=\left(1.8 \times{ }^{\circ} \mathrm{C}\right)+32
$$

Vertical coordinate information is referenced to the North American Vertical Datum of 1988 (NAVD 88).

Horizontal coordinate information is referenced to the North American Datum of 1983 (NAD 83).

Altitude, as used in this report, refers to distance above the North American Vertical Datum of 1988 (NAVD 88) unless otherwise specified.

Water year (WY) is the 12-month period, October 1 through September 30 , and is designated by the calendar year in which it ends. Thus, the water year ending September 30, 2006, is called the "2006" water year.

Specific conductance is given in microsiemens per centimeter at 25 degrees Celsius $(\mu \mathrm{S} / \mathrm{cm}$ at $\left.25^{\circ} \mathrm{C}\right)$.

Concentrations of chemical constituents in water in this report are given in milligrams per liter $(\mathrm{mg} / \mathrm{L})$ or micrograms per liter $(\mu \mathrm{g} / \mathrm{L})$.

\section{Abbreviations and Acronyms}

$\begin{array}{ll}\delta^{2} \mathrm{H} & \text { stable isotope of hydrogen } \\ \delta^{18} \mathrm{O} & \text { stable isotope of oxygen } \\ \mathrm{CFC} & \text { chlorofluorocarbon } \\ { }^{3} \mathrm{H} & \text { tritium } \\ \mathrm{PCA} & \text { principal components analysis } \\ \text { RPD } & \text { relative percent difference } \\ \text { USEPA } & \text { U.S. Environmental Protection Agency }\end{array}$




\title{
Groundwater Flow, Quality (2007-10), and Mixing in the Wind Cave National Park Area, South Dakota
}

\author{
By Andrew J. Long, ${ }^{1}$ Marc J. Ohms, ${ }^{2}$ and Jonathan D.R.G. McKaskey ${ }^{1}$
}

\section{Abstract}

A study of groundwater flow, quality, and mixing in relation to Wind Cave National Park in western South Dakota was conducted during 2007-11 by the U.S. Geological Survey in cooperation with the National Park Service because of waterquality concerns and to determine possible sources of groundwater contamination in the Wind Cave National Park area. A large area surrounding Wind Cave National Park was included in this study because to understand groundwater in the park, a general understanding of groundwater in the surrounding southern Black Hills is necessary. Three aquifers are of particular importance for this purpose: the Minnelusa, Madison, and Precambrian aquifers. Multivariate methods applied to hydrochemical data, consisting of principal component analysis (PCA), cluster analysis, and an end-member mixing model, were applied to characterize groundwater flow and mixing. This provided a way to assess characteristics important for groundwater quality, including the differentiation of hydrogeologic domains within the study area, sources of groundwater to these domains, and groundwater mixing within these domains. Groundwater and surface-water samples collected for this study were analyzed for common ions (calcium, magnesium, sodium, bicarbonate, chloride, silica, and sulfate), arsenic, stable isotopes of oxygen and hydrogen, specific conductance, and $\mathrm{pH}$. These 12 variables were used in all multivariate methods. A total of 100 samples were collected from 60 sites from 2007 to 2010 and included stream sinks, cave drip, cave water bodies, springs, and wells.

In previous approaches that combined PCA with endmember mixing, extreme-value samples identified by PCA typically were assumed to represent end members. In this study, end members were not assumed to have been sampled but rather were estimated and constrained by prior hydrologic knowledge. Also, the end-member mixing model was quantified in relation to hydrogeologic domains, which focuses model results on major hydrologic processes. Finally, conservative tracers were weighted preferentially in model calibration, which distributed model errors of optimized values, or

\footnotetext{
${ }^{1}$ U.S. Geological Survey.

${ }^{2}$ National Park Service.
}

residuals, more appropriately than would otherwise be the case. The latter item also provides an estimate of the relative effect of geochemical evolution along flow paths in comparison to mixing. The end-member mixing model estimated that Wind Cave sites received 38 percent of their groundwater inflow from local surface recharge, 34 percent from the upgradient Precambrian aquifer, 26 percent from surface recharge to the west, and 2 percent from regional flow. Artesian springs primarily received water from end members assumed to represent regional groundwater flow.

Groundwater samples were collected and analyzed for chlorofluorocarbons, dissolved gasses (argon, carbon dioxide, methane, nitrogen, and oxygen), and tritium at selected sites and used to estimate groundwater age. Apparent ages, or model ages, for the Madison aquifer in the study area indicate that groundwater closest to surface recharge areas is youngest, with increasing age in a downgradient direction toward deeper parts of the aquifer. Arsenic concentrations in samples collected for this study ranged from 0.28 to 37.1 micrograms per liter $(\mu \mathrm{g} / \mathrm{L})$ with a median value of $6.4 \mu \mathrm{g} / \mathrm{L}$, and 32 percent of these exceeded $10 \mu \mathrm{g} / \mathrm{L}$. The highest arsenic concentrations in and near the study area are approximately coincident with the outcrop of the Minnelusa Formation and likely originated from arsenic in shale layers in this formation. Sample concentrations of nitrate plus nitrite were less than 2 milligrams per liter for 92 percent of samples collected, which is not a concern for drinking-water quality. Water samples were collected in the park and analyzed for five trace metals (chromium, copper, lithium, vanadium, and zinc), the concentrations of which did not correlate with arsenic. Dye tracing indicated hydraulic connection between three water bodies in Wind Cave.

\section{Introduction}

Established in 1903, Wind Cave and the surrounding land became the eighth national park in the United States and the first one created to protect a cave (Wind Cave National Park, 2008). Wind Cave is located in western South Dakota (fig. 1) and is the fifth longest cave in the world with 218 kilometers $(\mathrm{km})$ of accessible passages (Gulden, 2011). Groundwater is an important resource for the park and, in particular, for 
Wind Cave. Groundwater drips from the ceiling of the cave at numerous locations and exists in ponds, lakes, and streams on the cave floor. The water table of the Madison aquifer is accessible at the deepest part of this cave, where subterranean lakes exist. These lakes are in hydraulic connection with the regionally extensive Madison aquifer, which exists in the northern Great Plains in several States, including South Dakota, North Dakota, Montana, Wyoming, Saskatchewan, and Manitoba. To understand the hydrology and hydrochemistry of Wind Cave, it is essential to understand the surrounding Madison aquifer within which the cave exists.

The National Park Service is concerned about water quality and possible sources of current (2011) or future groundwater contamination in Wind Cave National Park. To address these concerns, the U.S. Geological Survey in cooperation with the National Park Service conducted a study during 2007-11. The objective of this study was to characterize groundwater flow, quality, and mixing in the Wind Cave National Park area (fig. 1). This objective was carried out by assessing or estimating (1) groundwater gradients, flow directions, and transit times; (2) the occurrence and geospatial distributions of arsenic and nitrate and possible associations with trace metals; (3) groundwater sources for Wind Cave and sources of arsenic in the park, and (4) the relative proportions of different source waters contributing to Wind Cave and other areas of interest.

\section{Purpose and Scope}

The purpose of this report is to document results of a 4-year study of groundwater flow, quality, and mixing within and surrounding Wind Cave National Park in western South Dakota. Analytical results from a total of 100 samples collected from 2007 to 2010 from 60 selected sites including stream sinks, cave drip, cave water bodies, artesian and shallow springs, and wells are presented. Samples collected for this study were analyzed for common ions, arsenic, stable isotopes of oxygen and hydrogen, specific conductance, and $\mathrm{pH}$. Data from these samples were used in principal component analysis (PCA), cluster analysis, and end-member mixing, which are described in this report. Samples from selected sites also were analyzed for nitrate plus nitrite to determine if concentrations were of concern and for trace metals to assess possible existence of unusually high concentrations or correlations of these metals with arsenic. Samples were analyzed for chlorofluorocarbons (CFCs), dissolved gasses, and tritium for the purpose of estimating groundwater age, or residence time. Dye tracing using a fluorescent dye was used to determine the hydraulic connectivity between water bodies in Wind Cave.

This report provides information that is useful for understanding sources of groundwater to the park and the hydrologic interactions between the park's groundwater and surrounding groundwater. This report will be useful for identifying possible sources of contamination if such events occur in the future. Water-quality concerns, primarily related to arsenic, are addressed, and possible sources are described.

\section{Description of Study Area}

The study area is located in the southern part of the Black Hills of western South Dakota, which is a dome-type structure with sedimentary layers of Paleozoic age dipping radially outward on the flanks (fig. 1, table 1). Detailed geologic and hydrogeologic descriptions can be found in Gries and Martin (1981), Strobel and others (1999), and Redden and DeWitt (2008). Hydrochemical groundwater and cave studies in the Black Hills area include Back and others (1983), Bakalowicz and others (1987), Alexander and Davis (1989), Palmer and Palmer (1989), Ford and others (1993), Naus and others (2001), and Heakin (2004). Back (2011) investigated the hydrochemistry of Wind Cave National Park and interpreted data collected during 2007; these 2007 data are included in the analyses described in this report.

Underlying Paleozoic sedimentary layers and exposed at the central core of the Black Hills are Precambrian-age fractured metamorphic and igneous rocks, within which the Precambrian aquifer is contained (unit pe; fig. 1, table 1). The Paleozoic Formations overlie the Precambrian rocks and are exposed in roughly concentric rings surrounding the central core of the Black Hills. The Cambrian- and Ordovician-age Deadwood Formation is the lowermost Paleozoic Formation and contains the Deadwood aquifer (unit O€d; fig. 1). The Devonian-age Englewood Limestone and Mississippian-age Madison Limestone overlie the Deadwood Formation. The Madison aquifer (unit MDme; fig. 1) is a mature karst aquifer contained within the regionally extensive Madison Limestone (locally called the Pahasapa Limestone) and the Englewood Limestone, which are referred to as the Madison Limestone for the remainder of this report. The Madison aquifer contains fractures and solution-enlarged caves, and at least 15 large Black Hills caves are contained within this formation (Greene and Rahn, 1995). Wind Cave National Park maintains a database of more than 250 caves in the Black Hills that are more than 8 meters $(\mathrm{m})$ in length. The lower part of the Madison Limestone and the underlying Englewood Limestone generally have lower permeability than the upper part of the Madison aquifer in the Black Hills (Greene, 1993). Overlying the Madison Limestone is the Pennsylvanian- and Permian-age Minnelusa Formation (fig. 1), which contains the Minnelusa aquifer. The Minnelusa Formation is composed of interbedded sandstone, limestone, dolostone, and shale, with solution openings in carbonate layers including caves as much as $1,500 \mathrm{~m}$ in length (table 1). At the base of the Minnelusa Formation is a red clay shale that varies between 0 and $15 \mathrm{~m}$ thick in some areas of the Black Hills and is a residual weathered soil developed on the surface of the Madison Limestone (Cattermole, 1969; Gries, 1996). Overlying the Minnelusa Formation is the Permian-age Opeche Shale, which is a confining unit that underlies the Permian-age Minnekahta Limestone and the Permian- and Triassic-age Spearfish Formation (fig. 1). Overlying the Spearfish Formation are formations described in table 1, including the Tertiary-age White River Group, which contains the White River aquifer that overlies the Madison 


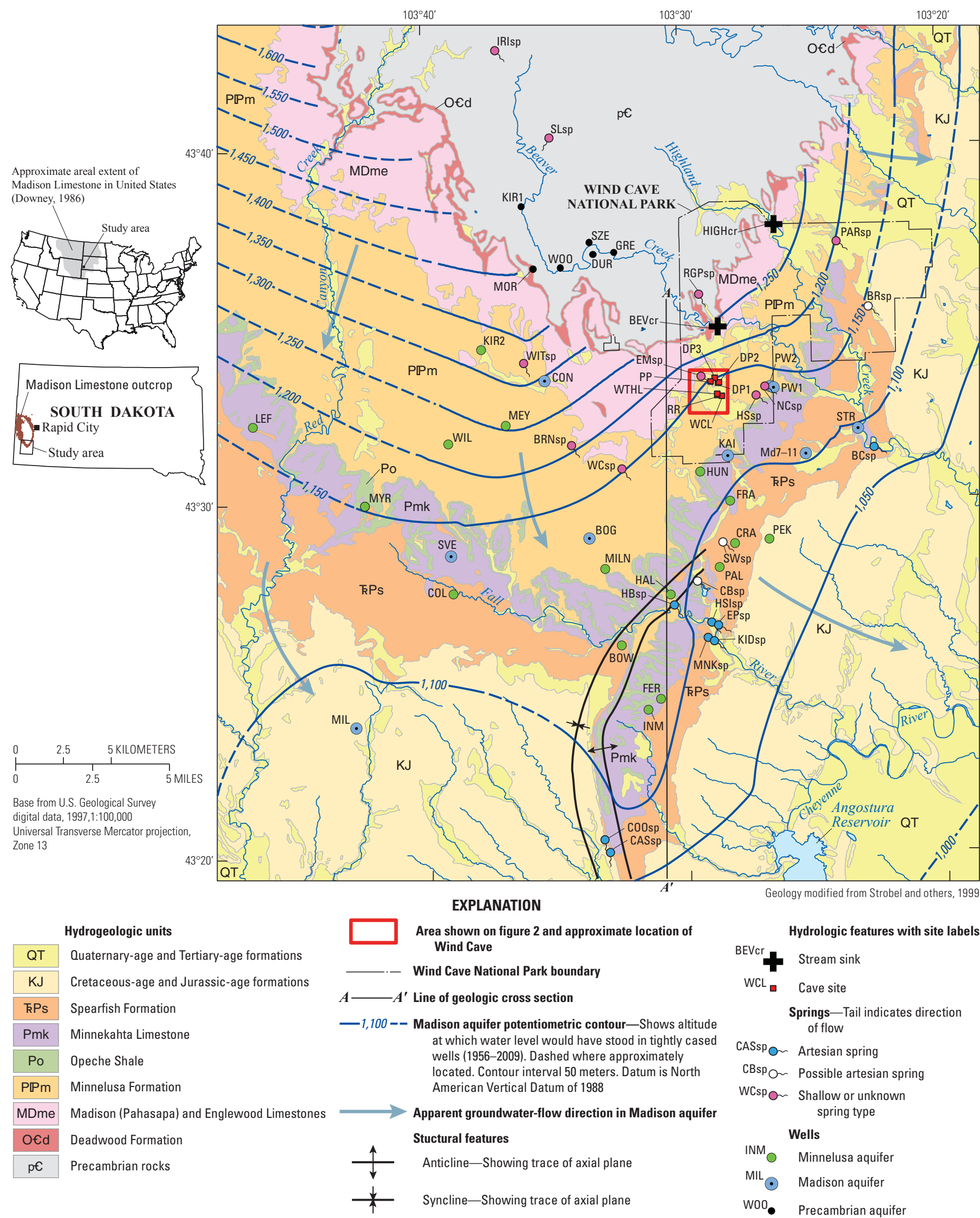

Figure 1. Study area showing hydrogeologic units and potentiometric surface of the Madison aquifer (geology modified from Strobel and others, 1999). 
and Minnelusa aquifers in some areas and might contribute recharge to these aquifers.

Wind Cave is located in the southeastern Black Hills, where sampled cave sites consist of cave drip (sites DP1, DP2, DP3) and subterranean water bodies (sites WCL, WTHL, PP, and RR; figs. 1 and 2, table 2). Land-surface altitudes in the study area range from about $1,700 \mathrm{~m}$ above the North American Vertical Datum of 1988 (NAVD 88) in the northwest to about $1,000 \mathrm{~m}$ in the southeast, and streams generally flow to the south and southeast (fig. 1). Surface recharge to the Minnelusa and Madison aquifers (units PPm and MDme; fig. 1) occurs on outcrop areas of the Minnelusa and Madison Formations. Additionally, streams flowing across these outcrop areas sink, fully or partially, into solution openings and fractures, primarily into the Madison aquifer and secondarily into the Minnelusa aquifer. Highland Creek flow rates at site HIGHcr (fig. 1) ranged from 0.02 to 0.05 cubic meters per second $\left(\mathrm{m}^{3} / \mathrm{s}\right)$ from 2002 to 2010 [30 measurements during this time; Wind Cave National Park written commun., (2010)]. Daily streamflow measurements for Beaver Creek at station BEVcr from 1990 to 2009 ranged from 0 to $2.4 \mathrm{~m}^{3} / \mathrm{s}$ with a mean of $0.06 \mathrm{~m}^{3} / \mathrm{s}$ (U.S. Geological Survey, 2011). The watersheds upstream from the Beaver Creek and Highland Creek (site HIGHcr) sites are almost entirely within Precambrian rocks.

Collectively, artesian springs are a large source of groundwater discharge in the study area. Eight artesian springs are located in the southeast part of the study area (fig. 1, table 2), including five along the Fall River (sites HBsp, HSIsp, KIDsp, MNKsp, EPsp), two near the southern boundary of the study area (sites CASsp and COOsp), and one near Beaver Creek (site BCsp) at the eastern boundary. Flow from Cascade Springs (site CASsp) ranged from 0.37 to $0.71 \mathrm{~m}^{3} / \mathrm{s}$ with a mean of $0.55 \mathrm{~m}^{3} / \mathrm{s}$ from 1976 to 1995 (station 06400497; U.S. Geological Survey, 2011).

Artesian springs generally emerge from or near outcrop areas of the Spearfish Formation (fig. 1), which generally has low permeability because of high shale content but also has flowing groundwater in fractures, cavities created by dissolved gypsum, and vertical breccia pipes. According to Hayes (1999), the throats of artesian springs in the southern Black Hills probably are breccia pipes that allow groundwater from deep bedrock aquifers to emerge from overlying formations. Cascade Springs (site CASsp), Cool Spring (site

Table 1. Description of hydrogeologic units.

[Summarized from Strobel and others, 1999; Redden and DeWitt, 2008]

\begin{tabular}{|c|c|c|c|c|c|}
\hline $\begin{array}{l}\text { Unit label } \\
\text { (fig. 1) }\end{array}$ & Formation and description & $\begin{array}{l}\text { Aquifer name or } \\
\text { hydrogeologic } \\
\text { description }\end{array}$ & Pore water type & $\begin{array}{l}\text { Thickness } \\
\text { (meters) }\end{array}$ & Age \\
\hline Qt & $\begin{array}{l}\text { Alluvium, colluvium, gravel, claystone, } \\
\text { poorly indurated sandstone, conglom- } \\
\text { erate }\end{array}$ & $\begin{array}{l}\text { Unconsolidated } \\
\text { aquifers }\end{array}$ & Intergranular & $0-140$ & $\begin{array}{l}\text { Quaternary and } \\
\text { Tertiary. }\end{array}$ \\
\hline $\mathrm{KJ}$ & $\begin{array}{l}\text { Undifferentiated shale, limestone, } \\
\text { sandstone, conglomerate, siltstone, } \\
\text { claystone, gypsum }\end{array}$ & $\begin{array}{l}\text { Aquifers and confin- } \\
\text { ing units }\end{array}$ & Intergranular, fractures & $800-2,300$ & $\begin{array}{l}\text { Cretaceous and } \\
\text { Jurrassic. }\end{array}$ \\
\hline $\mathrm{kP}$ & $\begin{array}{l}\text { Spearfish Formation - shale with in- } \\
\text { terbedded sandstone, siltstone, and } \\
\text { gypsum }\end{array}$ & $\begin{array}{l}\text { Low permeability in } \\
\text { general }^{\mathrm{a}}\end{array}$ & $\begin{array}{l}\text { Fractures, intergranular, } \\
\text { dissolved gypsum }\end{array}$ & $110-240$ & $\begin{array}{l}\text { Triassic and Perm- } \\
\text { ian. }\end{array}$ \\
\hline Pmk & Minnekahta Limestone & Minnekahta aquifer & $\begin{array}{l}\text { Fractures, solution } \\
\text { openings }\end{array}$ & $10-20$ & Permian. \\
\hline MDme & $\begin{array}{l}\text { Madison (Pahasapa) and Englewood } \\
\text { Limestones - also contains dolostone }\end{array}$ & $\begin{array}{l}\text { Madison aquifer, } \\
\text { mainly in upper } \\
\text { part }\end{array}$ & $\begin{array}{l}\text { Solution openings, } \\
\text { fractures }\end{array}$ & $90-320$ & $\begin{array}{l}\text { Mississippian and } \\
\text { Devonian. }\end{array}$ \\
\hline O€d & $\begin{array}{l}\text { Deadwood Formation - glauconitic sand- } \\
\text { stone, shale, siltstone, and conglomer- } \\
\text { ate }\end{array}$ & Deadwood aquifer & Fractures, intergranular & $0-150$ & $\begin{array}{l}\text { Ordovician and } \\
\text { Cambrian. }\end{array}$ \\
\hline pe & $\begin{array}{l}\text { Fractured metamorphosed quartzite and } \\
\text { metagraywacke with isolated areas of } \\
\text { granite and pegmatite }\end{array}$ & Precambrian aquifer & Fractures & Unknown & Precambrian. \\
\hline
\end{tabular}

a Except for fractured areas and areas of dissolved gypsum cavities. 


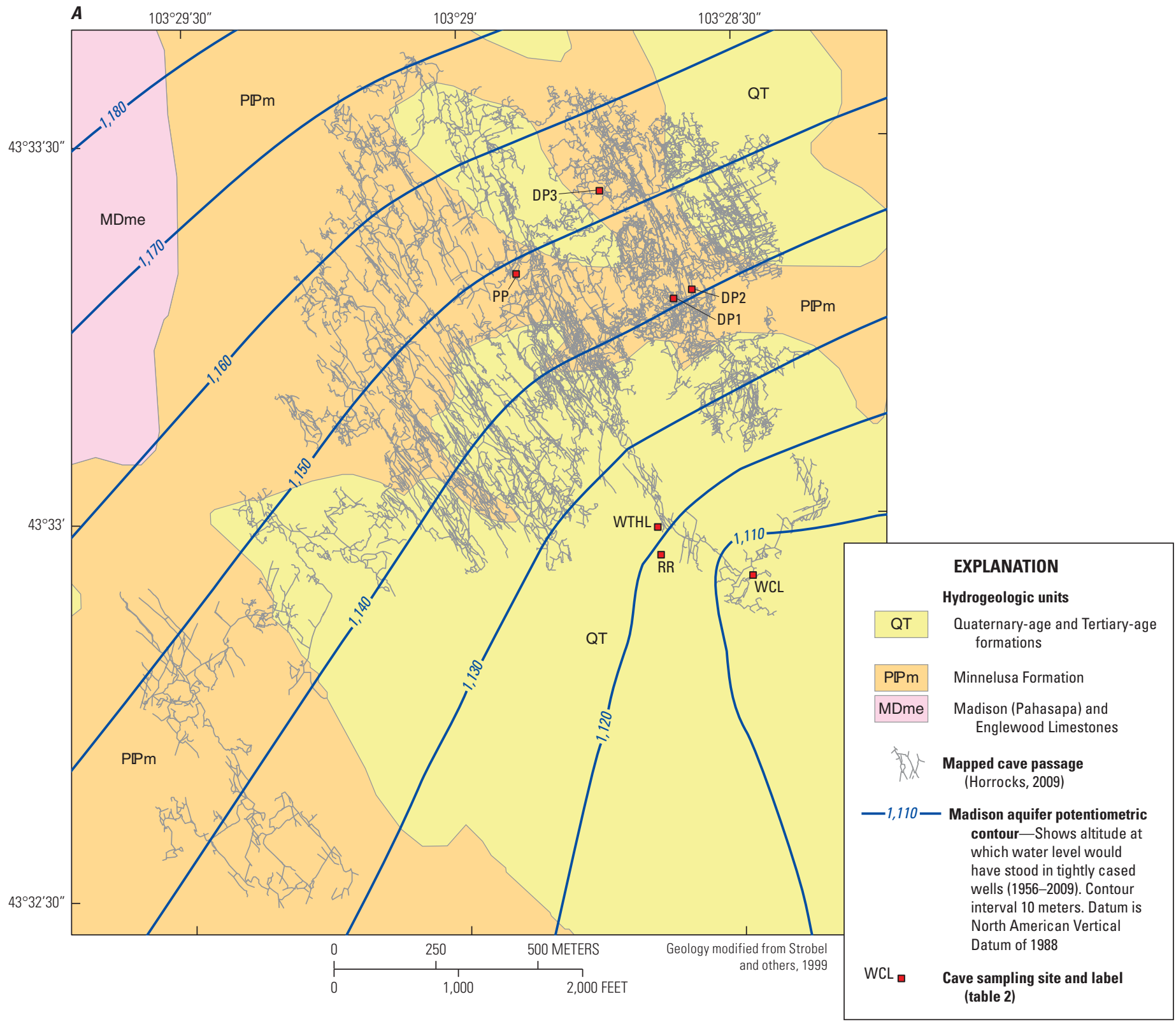

B

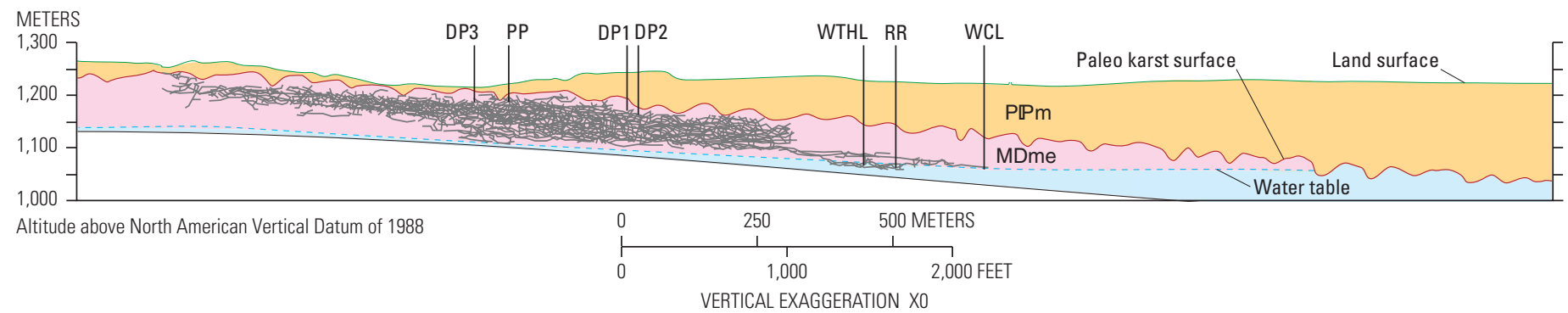

Figure 2. Mapped passages of Wind Cave and sampled sites shown in $(A)$ plan view and $(B)$ as a generalized hydrogeologic crosssection projected onto a single vertical plane (modified from Horrocks, 2009). 
Table 2. Sampled cave sites and springs.

$[\Delta \mathrm{h}$, estimated height in meters $(\mathrm{m})$ of the Madison aquifer hydraulic head above (positive values) that of the Minnelusa aquifer; NAVD 88 , North American Vertical Datum of 1988; --, not applicable]

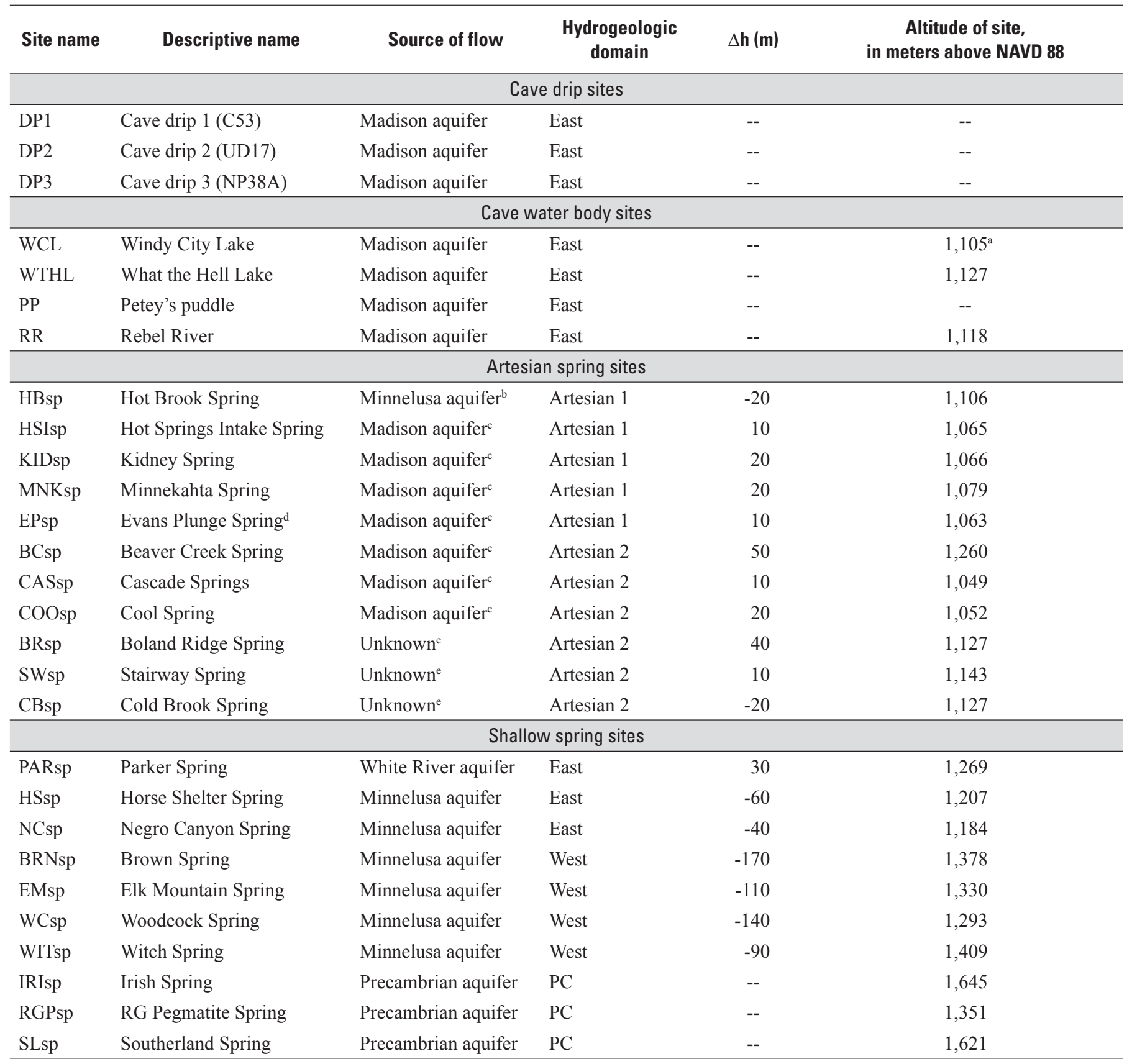

${ }^{a}$ Altitude at which staff gage equals zero (surveyed May 28, 2008).

${ }^{\mathrm{b}}$ Assumed to flow primarily from Minnelusa aquifer but could include water from other aquifers.

${ }^{\mathrm{c}}$ Assumed to flow primarily from Madison aquifer but could include water from other aquifers.

${ }^{d}$ No sample available.

${ }^{\mathrm{e}}$ Possibly artesian flowing from Madison or Minnelusa aquifer or both. 
COOsp), Hot Brook Spring (site HBsp), Evans Plunge Spring (site EPsp), and Beaver Creek Spring (site BCsp) are considered artesian and probably flow primarily from the Madison aquifer (Rahn and Gries, 1973; Back and others, 1983; Hayes, 1999; Naus and others, 2001; Driscoll and others, 2002).

Consistent with these previous studies identifying the Madison aquifer as the primary source of artesian springs is an assessment of vertical hydraulic-head gradients described in this report, where the Madison aquifer was estimated to be higher than in the Minnelusa aquifer for all artesian springs except Hot Brook Spring (table 2).

In addition to the previously classified springs, Hot Springs Intake Spring (site HSIsp) and Kidney Spring (site KIDsp) were classified in this study as artesian (previously unclassified) because of similarity in temperature and hydrochemistry to those of the other artesian springs near the Fall River (fig. 1). Three springs (sites BRsp, SWsp, and CBsp) are not known to be artesian but are hydrochemically and geologically similar to known artesian springs, and thus the Madison aquifer and possibly the Minnelusa aquifer might be a source of flow for these springs (table 2). Also, breccia pipes that do not extend to the land surface probably exist in the study area and facilitate groundwater exchange between the Madison, Minnelusa, and possibly other overlying aquifers (Brobst and Epstein, 1963; Hayes, 1999).

\section{Methods}

Assessment of hydraulic gradients and flow direction were used in interpreting hydrochemical analyses. Plotting the geospatial distributions of arsenic concentrations, nitrate plus nitrite concentrations, specific conductance values, and groundwater age were useful for characterizing hydrochemical differences and gradients across the study area and provided supplemental information for assessing groundwater flow. Multivariate methods to estimate groundwater mixing consisted of principal component analysis (PCA), cluster analysis, and end-member mixing applied to hydrochemical data. Application of these multivariate methods presented in this report is a summary of results described by Long and Valder (2011).

\section{Sample Collection and Hydrochemical Data}

Sites that were sampled for this study include stream sinks; cave drip; cave water bodies; artesian springs primarily flowing from the Madison aquifer; shallow springs flowing from the White River, Minnelusa, and Precambrian aquifers; and wells open to the Minnelusa, Madison, and Precambrian aquifers (fig. 1, table 3). A total of 100 samples were collected from 60 sites from 2007 to 2010, and 93 percent of the sites were sampled at least once during 2009 and 2010. Multiple samples were collected during different months or years for
19 sites, with as many as 5 samples per site from 2007 to 2010 , and were used to assess seasonal and annual variability. Five samples were collected from 5 of the 19 sites (four samples during 2007 and one during 2009), and 2 to 4 samples were collected from 2007 to 2009 for the other 14 sites.

Samples collected for this study were analyzed for common ions (calcium, magnesium, sodium, bicarbonate, chloride, silica, and sulfate), arsenic, stable isotopes of oxygen $\left(\delta^{18} \mathrm{O}\right)$ and hydrogen $\left(\delta^{2} \mathrm{H}\right)$, specific conductance, and $\mathrm{pH}$. These 12 variables were used in principal component analysis (PCA), cluster analysis, and end-member mixing. Also, samples collected during 2007 were analyzed for nitrate plus nitrite (table 3). Samples analyzed for chlorofluorocarbons (CFCs), dissolved gasses (argon, carbon dioxide, nitrogen, and oxygen), and tritium $\left({ }^{3} \mathrm{H}\right)$ were collected at selected sites in the study area (table 3 ) for the purpose of estimating groundwater age, or residence time. Hydrochemical data for all sites described in this report as well as other sites in the study area, including historical data, are available from the National Water Information System (U.S. Geological Survey, 2011).

Samples were collected according to methods described in U.S. Geological Survey (variously dated). Samples were analyzed for common ions and arsenic by the U.S. Geological Survey National Water Quality Laboratory in Lakewood, Colorado, using methods described by Fishman and Friedman (1989), Fishman (1993), and Garbarino and others (2006). Values of $\delta^{18} \mathrm{O}$ and $\delta^{2} \mathrm{H}$ were determined by the U.S. Geological Survey Reston Isotope Laboratory in Reston, Virginia, using a gaseous hydrogen equilibration procedure described by Révész and Coplen (2008a, 2008b). Samples were analyzed for CFCs and dissolved gasses at the Reston Chlorofluorocarbon Laboratory in Reston, Virginia. CFCs were analyzed using a purge-and-trap gas chromatography procedure (Shimadzu GC-8AIE) with an electron capture detector, and dissolved gases (argon, carbon dioxide, nitrogen, and oxygen) were determined by gas chromatography (Hewlett Packard model 5890; http://water.usgs.gov/lab/). Samples were analyzed for tritium at the Tritium Laboratory in Menlo Park, California, by electrolytic enrichment and liquid scintillation (Thatcher and others, 1977).

Quality-control samples consisted of 12 pairs of replicate samples and 5 field-equipment blank samples. The relative percent difference (RPD) is defined as the difference between the replicate and sample values divided by the sample value times 100. The RPDs for each variable for each replicate pair was 6 percent or less for 96 percent of the data. Larger RPD values resulted from one sodium pair (14 percent RPD), one silica pair (9 percent RPD), and two arsenic pairs (11 and 23 percent RPDs). The largest RPD ( 23 percent) was for a replicate pair with low arsenic concentrations of 0.25 and 0.28 $\mu \mathrm{g} / \mathrm{L}$. The conservative tracers, chloride, $\delta^{18} \mathrm{O}$, and $\delta^{2} \mathrm{H}$, had RPDs of less than 3, 1, and 1 percent, respectively. Laboratory analyses of all field-equipment blank samples were below detection limits. 
Table 3. Water-quality sampling sites and constituents analyzed in samples.

[SC, specific conductance; CFC, chlorofluorocarbons; --, not applicable or not analyzed]

\begin{tabular}{|c|c|c|c|c|c|c|c|c|c|c|c|c|}
\hline \multirow[b]{2}{*}{$\begin{array}{l}\text { Site } \\
\text { name }\end{array}$} & \multirow[b]{2}{*}{ Descriptive name } & \multirow[b]{2}{*}{ Station number } & \multirow[b]{2}{*}{ Station name } & \multirow[b]{2}{*}{$\begin{array}{l}\text { Source } \\
\text { aquifer }\end{array}$} & \multirow[b]{2}{*}{$\begin{array}{l}\text { Number } \\
\text { of } \\
\text { samples }^{\mathrm{a}}\end{array}$} & \multicolumn{7}{|c|}{ Constituents analyzed in samples } \\
\hline & & & & & & $\begin{array}{l}\text { Common ions, } \\
\text { arsenic, } \\
\text { stable iso- } \\
\text { topes, } \\
\text { SC, pH }\end{array}$ & $\begin{array}{c}\text { Nitrate } \\
\text { plus nitrite }\end{array}$ & $\begin{array}{l}\text { Trace } \\
\text { metals }\end{array}$ & Tritium & CFC & $\begin{array}{l}\text { Dissolved } \\
\text { gases }\end{array}$ & $\begin{array}{l}\text { Fluores- } \\
\text { cein } \\
\text { dye }\end{array}$ \\
\hline \multicolumn{13}{|c|}{ Stream sink sites } \\
\hline $\mathrm{BevCr}$ & Beaver Creek sink & 06402430 & $\begin{array}{r}\text { Beaver Creek near } \\
\text { Pringle, S. Dak. }\end{array}$ & -- & 3 & Yes & Yes & Yes & Yes & -- & -- & -- \\
\hline HIGHcr & Highland Creek sink & 433745103261900 & $\begin{array}{l}\text { Highland Creek above } \\
\text { Madison outcrop near } \\
\text { Pringle, S. Dak. }\end{array}$ & -- & 5 & Yes & Yes & -- & -- & -- & -- & -- \\
\hline \multicolumn{13}{|c|}{ Cave drip sites } \\
\hline DP1 & Cave drip 1 (C53) & 433302103281507 & 6S 5E12DBAB7 & Madison & 2 & Yes & Yes & -- & -- & -- & -- & -- \\
\hline DP2 & Cave drip 2 (UD17) & 433302103281508 & 6S 5E12DBAB8 & Madison & 3 & Yes & Yes & Yes & -- & -- & -- & -- \\
\hline DP3 & Cave drip 3 (NP38A) & 433302103281509 & 6S 5E12DBAB9 & Madison & 3 & Yes & Yes & Yes & Yes & -- & -- & -- \\
\hline \multicolumn{13}{|c|}{ Cave water body sites } \\
\hline PP & Petey's puddle & 433302103281504 & 6S 5E12DBAB4 & Madison & 1 & Yes & Yes & -- & -- & -- & -- & -- \\
\hline $\mathrm{RR}$ & Rebel River & 433302103281506 & 6S 5E12DBAB6 & Madison & 1 & Yes & Yes & -- & -- & -- & -- & Yes \\
\hline WCL & Windy City Lake & 433302103281501 & 6S 5E12DBAB & Madison & 2 & Yes & Yes & -- & -- & -- & -- & Yes \\
\hline WTHL & What the Hell Lake & 433302103281502 & 6S 5E12DBAB2 & Madison & 2 & Yes & Yes & -- & Yes & Yes & -- & -- \\
\hline \multicolumn{13}{|c|}{ Artesian spring sites } \\
\hline HBsp & Hot Brook Spring & 432703103302801 & 7S 5E10DCBA & Minnelusa $^{\mathrm{b}}$ & 5 & Yes & Yes & Yes & Yes & Yes & Yes & -- \\
\hline BCsp & Beaver Creek Spring & 433128103223401 & 6S 6E14CDB & Madison $^{\mathrm{c}}$ & 5 & Yes & Yes & -- & Yes & Yes & Yes & -- \\
\hline CASsp & Cascade Springs & 432006103330501 & 8S 5E20CDAB & Madison $^{\mathrm{c}}$ & 3 & Yes & -- & -- & Yes & Yes & Yes & -- \\
\hline COOsp & Cool Spring & 432028103331601 & 8S 5E20BDCB & Madison $^{\mathrm{c}}$ & 1 & Yes & -- & -- & Yes & Yes & Yes & -- \\
\hline HSIsp & Hot Springs Intake Spring & 432632103285302 & 7S 5E14DDDA & Madison $^{\mathrm{c}}$ & 5 & Yes & Yes & -- & -- & Yes & Yes & -- \\
\hline KIDsp & Kidney Spring & 432605103285401 & 7S 5E14DDD & Madison $^{\mathrm{c}}$ & 1 & Yes & -- & -- & Yes & Yes & Yes & -- \\
\hline MNKsp & Minnekahta Spring & 432605103290901 & 7S 5E14DCD & Madison $^{\mathrm{c}}$ & 1 & Yes & -- & -- & Yes & Yes & Yes & -- \\
\hline BRsp & Boland Ridge Spring & 433525103224401 & 5S 6E26BBCD & Unknown $^{\mathrm{d}}$ & 1 & Yes & -- & Yes & -- & -- & -- & -- \\
\hline CBsp & Cold Brook Spring & 432744103293401 & 7S 5E11BAAB & Unknown $^{\mathrm{d}}$ & 1 & Yes & -- & -- & -- & -- & -- & -- \\
\hline SWsp & Stairway Spring & 432849103283201 & 6S 5E36CDBB & Unknown $^{\mathrm{d}}$ & 1 & Yes & -- & -- & -- & -- & -- & -- \\
\hline
\end{tabular}


Table 3. Water-quality sampling sites and constituents analyzed in samples.-Continued

[SC, specific conductance; $\mathrm{CFC}$, chlorofluorocarbons; --, not applicable or not analyzed]

\begin{tabular}{|c|c|c|c|c|c|c|c|c|c|c|c|c|}
\hline \multirow[b]{2}{*}{$\begin{array}{c}\text { Site } \\
\text { name }\end{array}$} & \multirow[b]{2}{*}{ Descriptive name } & \multirow[b]{2}{*}{ Station number } & \multirow[b]{2}{*}{ Station name } & \multirow[b]{2}{*}{$\begin{array}{l}\text { Source } \\
\text { aquifer }\end{array}$} & \multirow[b]{2}{*}{$\begin{array}{c}\text { Number } \\
\text { of } \\
\text { samples }^{a}\end{array}$} & \multicolumn{7}{|c|}{ Constituents analyzed in samples } \\
\hline & & & & & & $\begin{array}{l}\text { Common ions, } \\
\text { arsenic, } \\
\text { stable iso- } \\
\text { topes, } \\
\text { SC, pH }\end{array}$ & $\begin{array}{c}\text { Nitrate } \\
\text { plus nitrite }\end{array}$ & $\begin{array}{l}\text { Trace } \\
\text { metals }\end{array}$ & Tritium & CFC & $\begin{array}{l}\text { Dissolved } \\
\text { gases }\end{array}$ & $\begin{array}{l}\text { Fluores- } \\
\text { cein } \\
\text { dye }\end{array}$ \\
\hline \multicolumn{13}{|c|}{ Shallow spring sites } \\
\hline PARsp & Parker Spring & 433717103235401 & 5S 6E15BBAC & White River & 1 & Yes & -- & Yes & -- & -- & -- & -- \\
\hline BRNsp & Brown Spring & 433137103342101 & 6S 5E18CABD & Minnelusa & 1 & Yes & -- & -- & -- & -- & -- & -- \\
\hline EMsp & Elk Mountain Spring & 433332103291801 & $6 \mathrm{~S} 5 \mathrm{E} 2 \mathrm{ACBD}$ & Minnelusa & 1 & Yes & -- & Yes & -- & -- & -- & -- \\
\hline HSsp & Horse Shelter Spring & 433258103270801 & 6S 6E 7BAAC & Minnelusa & 1 & Yes & -- & -- & -- & -- & -- & -- \\
\hline IRIsp & Irish Spring & 434249103370401 & 4S 4E11CCBB & Minnelusa & 1 & Yes & -- & -- & -- & -- & -- & -- \\
\hline NCsp & Negro Canyon Spring & 433312103264701 & 6S 6E 6DCAA & Minnelusa & 1 & Yes & -- & Yes & -- & -- & -- & -- \\
\hline WCsp & Woodcock Spring & 433056103322201 & 6S 5E21BCBC & Minnelusa & 1 & Yes & -- & -- & -- & -- & -- & -- \\
\hline WITsp & Witch Spring & 433611103335801 & 5S 4E35DDBC & Minnelusa & 1 & Yes & -- & -- & -- & -- & -- & -- \\
\hline RGPsp & RG Pegmatite Spring & 433551103291901 & 5S 5E23DBCD & Precambrian & 1 & Yes & -- & Yes & -- & -- & -- & -- \\
\hline SLsp & Southerland Spring & 434020103350101 & 4S 4E25DB & Precambrian & 1 & Yes & -- & -- & -- & -- & -- & -- \\
\hline \multicolumn{13}{|c|}{ Well sites } \\
\hline BOW & -- & 432555103323201 & 7S 5E20AACA & Minnelusa & 1 & Yes & -- & -- & -- & -- & -- & -- \\
\hline $\mathrm{COL}$ & -- & 432727103390201 & 7S 4E 9BACA & Minnelusa & 1 & Yes & -- & -- & -- & -- & -- & -- \\
\hline CRA & -- & 432846103280501 & $6 \mathrm{~S} 5 \mathrm{E} 36 \mathrm{DCBC}$ & Minnelusa & 1 & Yes & -- & -- & -- & -- & -- & -- \\
\hline FER & -- & 432437103305701 & 7S 5E27CCCD & Minnelusa & 1 & Yes & -- & -- & -- & -- & -- & -- \\
\hline FRA & -- & 432437103305701 & 7S 5E27CCCD & Minnelusa & 1 & Yes & -- & -- & -- & -- & -- & -- \\
\hline HAL & -- & 432720103303701 & 7S 5E15BABB & Minnelusa & 1 & Yes & -- & -- & -- & -- & -- & -- \\
\hline HUN & -- & 433034103284701 & $6 \mathrm{~S} 5 \mathrm{E} 23 \mathrm{DB}$ & Minnelusa & 4 & Yes & Yes & -- & Yes & Yes & Yes & -- \\
\hline INM & -- & 432332103314801 & 7S 5E33ABDD & Minnelusa & 1 & Yes & -- & -- & -- & -- & -- & -- \\
\hline KIR2 & -- & 433420103374901 & 5S 4E34BDDB & Minnelusa & 1 & Yes & -- & -- & -- & -- & -- & -- \\
\hline LEF & -- & 433215103464401 & $6 \mathrm{~S} 3 \mathrm{E} 5 \mathrm{CCD}$ & Minnelusa & 1 & Yes & -- & -- & -- & -- & -- & -- \\
\hline MEY & -- & 433215103365801 & 6S 4E11CCDB & Minnelusa & 1 & Yes & -- & -- & -- & -- & -- & -- \\
\hline MILN & -- & 432806103330801 & 8S 5E 5CADD & Minnelusa & 1 & Yes & -- & -- & -- & -- & -- & -- \\
\hline MYR & -- & 433003103420701 & 7S 3E36CBCC & Minnelusa & 1 & Yes & -- & -- & -- & -- & -- & -- \\
\hline PAL & -- & 432806103284101 & 7S 5E 1CBCC & Minnelusa & 1 & Yes & -- & -- & -- & -- & -- & -- \\
\hline PEK & -- & 432852103264401 & 6S 6E31DBDA & Minnelusa & 1 & Yes & -- & -- & -- & -- & -- & -- \\
\hline
\end{tabular}


Table 3. Water-quality sampling sites and constituents analyzed in samples.-Continued

[SC, specific conductance; CFC, chlorofluorocarbons; --, not applicable or not analyzed]

\begin{tabular}{|c|c|c|c|c|c|c|c|c|c|c|c|c|}
\hline \multirow[b]{2}{*}{$\begin{array}{c}\text { Site } \\
\text { name }\end{array}$} & \multirow[b]{2}{*}{ Descriptive name } & \multirow[b]{2}{*}{ Station number } & \multirow[b]{2}{*}{ Station name } & \multirow[b]{2}{*}{$\begin{array}{l}\text { Source } \\
\text { aquifer }\end{array}$} & \multirow[b]{2}{*}{$\begin{array}{c}\text { Number } \\
\text { of } \\
\text { samples }^{a}\end{array}$} & \multicolumn{7}{|c|}{ Constituents analyzed in samples } \\
\hline & & & & & & $\begin{array}{l}\text { Common ions, } \\
\text { arsenic, } \\
\text { stable iso- } \\
\text { topes, } \\
\text { SC, pH }\end{array}$ & $\begin{array}{c}\text { Nitrate } \\
\text { plus nitrite }\end{array}$ & $\begin{array}{l}\text { Trace } \\
\text { metals }\end{array}$ & Tritium & CFC & $\begin{array}{l}\text { Dissolved } \\
\text { gases }\end{array}$ & $\begin{array}{l}\text { Fluores- } \\
\text { cein } \\
\text { dye }\end{array}$ \\
\hline \multicolumn{13}{|c|}{ Well sites-Continued } \\
\hline WIL & -- & 433141103390901 & 6S 4E16CABB & Minnelusa & 1 & Yes & -- & -- & -- & -- & -- & -- \\
\hline BOG & -- & 432858103334201 & 6S 5E31DA & Madison & 2 & Yes & Yes & -- & Yes & Yes & -- & -- \\
\hline $\mathrm{CON}$ & -- & 433326103352001 & $6 \mathrm{~S} 4 \mathrm{E} 1 \mathrm{DB}$ & Madison & 2 & Yes & Yes & -- & Yes & Yes & Yes & -- \\
\hline KAI & -- & 433114103281601 & 6S 5E24BAAA & Madison & 2 & Yes & Yes & -- & -- & -- & -- & -- \\
\hline Md7-11 & -- & 433115103251401 & $\begin{array}{c}\text { 6S 6E21BBBB } \\
\text { (CU91A) }\end{array}$ & Madison & 1 & Yes & Yes & -- & Yes & Yes & Yes & -- \\
\hline MIL & -- & 432340103421501 & 7S 3E36CBDC & Madison & 2 & Yes & Yes & -- & -- & Yes & -- & -- \\
\hline PW1 & -- & 433311103263101 & 6S 6E 6DDA & Madison & 2 & Yes & Yes & -- & Yes & Yes & Yes & Yes \\
\hline PW2 & -- & 433311103263102 & 6S 6E 6DDA2 & Madison & 2 & Yes & Yes & -- & Yes & Yes & Yes & Yes \\
\hline STR & -- & 433150103230501 & 6S 6E15ABDD & Madison & 5 & Yes & Yes & -- & Yes & Yes & Yes & -- \\
\hline SVE & -- & 432825103391201 & 7S 4E 4BAC & Madison & 1 & Yes & Yes & -- & Yes & Yes & Yes & -- \\
\hline DUR & -- & 433658103332301 & 5S 5E17BCDB & Precambrian & 1 & Yes & -- & -- & -- & -- & -- & -- \\
\hline GRE & -- & 433701103323401 & 5S 5E17ACDD & Precambrian & 1 & Yes & -- & -- & -- & -- & -- & -- \\
\hline KIR1 & -- & 433821103360901 & 5S 4E 2DDBD & Precambrian & 1 & Yes & -- & -- & -- & -- & -- & -- \\
\hline MOR & -- & 433635103354301 & 5S 4E13CCAC & Precambrian & 1 & Yes & -- & -- & -- & -- & -- & -- \\
\hline SZE & -- & 433718103333101 & 5S 5E17BBBA & Precambrian & 1 & Yes & -- & -- & -- & -- & -- & -- \\
\hline WOO & -- & 433636103343901 & 5S 5E18CCAC & Precambrian & 1 & Yes & -- & -- & -- & -- & Yes & -- \\
\hline
\end{tabular}

${ }^{a}$ Not including quality-control replicate samples.

${ }^{\mathrm{b}}$ Assumed to flow primarily from Minnelusa aquifer but could include water from other aquifers.

${ }^{\mathrm{c}}$ Assumed to flow primarily from Madison aquifer but could include water from other aquifers.

d Possibly artesian flowing from Madison or Minnelusa aquifer or both. 


\section{Principal Component and Cluster Analyses}

Principal component analysis (PCA) is a linear transformation of data in multidimensional space, where the transformed axes, or principal components, align with the greatest variances in the data (Davis, 2002). Each principal component is a newly created variable, which is a linear combination of all original variables. PCA is a method that is used to graphically plot complex multivariate datasets and elucidate data patterns that otherwise might not be noticed. The term "scores" refers to the values of the new variables in the transformed space, and by plotting the data points as scores in this space, sample relations and groupings may become evident. PCA commonly is used to identify extreme-value points, which might be considered as possible end members (Davis, 2002).

The assignment of data points to a specified number of groups, or clusters, based on similarity of data is referred to as cluster analysis. The method described in this report partitions the data points by iteratively assigning each data point to a cluster that minimizes the sum of Euclidian distances between data points and the nearest cluster centroid (Seber, 1984; Spath, 1985). The scores from the PCA were used as the data from which clusters were generated to reduce the clustering error caused by data error or multicollinearity (Suk and Lee, 1999).

\section{End-Member Mixing}

For an end-member mixing analysis, it is assumed that each water sample consists of water from one or more end members in varying proportions. An end member is defined as water having a characteristic geochemical signature that best represents a source of groundwater inflow to the system. An end member represents the hydrochemistry of a particular source of groundwater inflow, such as recharge within the study area or groundwater flowing into the study area. In some cases, an end member might be a point source of inflow, such as a sinking stream; in other cases, it might represent the integration, or characteristic hydrochemical signature, of a distributed source, such as areally distributed recharge or regional groundwater inflow. A two end-member model adapted from Fritz and others (1976) is described as

$$
\hat{c}=f_{1} E_{1}+f_{2} E_{2},
$$

where $\hat{c}$ is the concentration of a mixed water sample, $f_{1}$ and $f_{2}$ are the fractions, or mixing proportions, of end-members 1 and 2, respectively, and $E_{1}$ and $E_{2}$ are the respective end-member concentrations.

A common approach in applying an end-member mixing model is to collect samples from assumed end-member waters and to then determine the mixing proportion, or contribution, of each end member in samples assumed to contain mixed water. In this study, it was not assumed that end members had been sampled, but rather these were estimated by inverse modeling using a generalized form of equation 1 that allows for any number of end members and variables:

$$
c_{i, j}=\sum_{k=1}^{n} f_{i, k} E_{j, k},
$$

where $c_{i, j}$ is the concentration of variable $j$ for site $i ; f_{i, k}$ is the fraction, or mixing proportion, of end-member $k$ that is associated with site $i$; and $E_{j, k}$ is the end-member concentration for variable $j$ and end-member $k$. Equation 2 was programmed in Fortran, and the mixing proportions $f_{i, k}$ and end-member hydrochemical values $E_{j, k}$ were estimated by inverse modeling using the parameter optimization software, PEST (Doherty, 2005), which uses optimization methods described by Levenberg (1944) and Marquardt (1963). This process began with user-specified initial estimates for the values of $f_{i, k}$ and $E_{j, k}$. Then, the calculated concentrations $\hat{c}_{i, j}$ were compared to observed values $c_{i, j}$, and the differences, or residuals, between calculated and observed values $\hat{c}_{i, j}-c_{i, j}$ were minimized by optimizing the values of $f_{i, k}$ and $E_{j, k}$ iteratively. New residuals were calculated for each iteration, and $f_{i, k}$ and $E_{j, k}$ were adjusted for the next iteration until no further reduction of residuals occurred.

The primary limitation of this model is that hydrochemical evolution of groundwater along a flow path is neglected. For the current study, this limitation was diminished by weighting the calibration data for conservative tracers more heavily than for other variables during inverse modeling.

\section{Groundwater Age Dating}

Samples were collected and analyzed for CFCs and tritium for the purpose of estimating groundwater age, or the amount of time that a sampled groundwater has been out of contact with the atmosphere. This also is known as groundwater residence time and is important because it provides estimates of groundwater transit times, if greater than about 5 to 10 years. The CFCs are anthropogenic tracers that are present in the atmosphere and have become assimilated with rainwater and surface water (Cook and others, 1996; Oster and others, 1996; Plummer and Busenberg, 2000). The CFCs then enter groundwater with infiltrating precipitation or sinking streams. Groundwater age can be estimated by comparing concentrations in groundwater samples to historical atmospheric concentrations for different $\mathrm{CFC}$ species, including $\mathrm{CFC}-11$, $\mathrm{CFC}-12$, and $\mathrm{CFC}-113$. The $\mathrm{CFCs}$ in water exposed to the atmosphere become equilibrated with atmospheric concentrations, but in groundwater that is not in contact with the open atmosphere, CFCs generally remain at the concentration of recharge water, except in reducing environments. Atmospheric tritium concentrations in past decades were elevated when CFC concentrations were relatively low, and both of these were at low concentrations or not present in the atmosphere before about 1950 (fig. 3). 


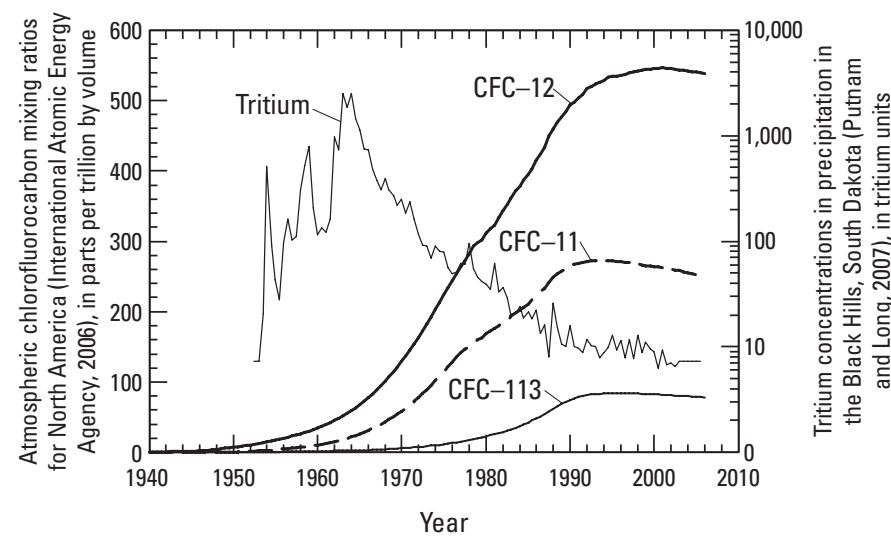

Figure 3. Chlorofluorocarbon (CFC) and tritium concentrations in the atmosphere.

\section{Groundwater Flow, Quality, and Mixing Assessments}

Results of this study are described first in relation to general groundwater flow, the understanding of which is necessary for interpreting the results of methods applied to hydrochemical data. This assessment consists of a description of groundwater hydraulic gradients and flow directions, sources and flow rates of springs, and dye tracing. Potentiometric maps of the Madison and Minnelusa aquifers (figs. 1 and 4, respectively) were constructed and used to estimate general groundwater-flow directions, horizontal hydraulic gradients in the Madison and Minnelusa aquifers, and vertical hydraulic gradients between these two aquifers. Next, the geospatial distributions and other relations of water-quality constituents in the study area are described. Geospatial distributions of hydrochemical data primarily indicated differences between surface recharge areas with young groundwater and deep aquifer areas with older groundwater. Finally, an assessment of groundwater mixing is described, where five hydrogeologic domains and groundwater flow between these domains were characterized on the basis of multivariate analyses of hydrochemical data.

\section{Groundwater Flow}

The mapped passages of Wind Cave are almost entirely within the Madison aquifer's unsaturated zone and below an unsaturated part of the Minnelusa aquifer (fig. 2). Infiltration of precipitation on the outcrop of the Minnelusa Formation seeps downward, enters unsaturated parts of the Madison aquifer, and drips from the ceiling of Wind Cave at numerous sites. Similarly, this type of recharge to the Madison aquifer from the Minnelusa aquifer is assumed also to occur elsewhere in the study area. Windy City Lake (site WCL; figs. 1 and 2) is a body of water at the deepest part of the cave and exists because of this hydrologic connection between the Madison and Minnelusa aquifers. Windy City Lake rises and declines with the surrounding water table as indicated by a comparison of water levels in the lake and well Md7-11 (fig. 5). Before 1999, another similar lake existed in proximity to Wind City Lake called Calcite Lake. Sometime before the end of 2000, the Madison aquifer water table and the levels of both lakes increased in altitude, which resulted in the merging of the two lakes.

What the Hell Lake (site WTHL; figs. 1 and 2) was filled unexpectedly in 1996 after being dry for decades (Shouse, 2004). Wind Cave National Park staff observed this water body on July 18, 1996, and stated that a new pool had formed, which did not exist during a previous visit to the same site on June 12, 1996, and this site has contained water continuously from that time until the present (Wind Cave National Park, written commun., 2011). The filling of site WTHL might have been the result of perched groundwater in caverns above this site that emptied rapidly. Perched water frequently is observed in Black Hills caves and results from areas of impermeable limestone or the accumulation of clay sediments on cave floors (Long, 2009). Rapid outflow from a perched water body might have been the result of spillover through an outlet as water levels were rising or from the dislodgement of clay that had filled an outlet. Years 1995-2000 was a period in which the water level at site WCL was rising (fig. 5), which indicates relatively high recharge and infiltration rates. Groundwater in a karst aquifer unsaturated zone can be decades old in some cases (Even and others, 1986), and if perched groundwater above site WTHL had been in storage for decades and then released, this could explain why site WTHL was dry for decades before filling.

\section{Groundwater Gradients and Flow Directions}

A potentiometric-surface map of the Madison aquifer was constructed on the basis of water-level data available from the U.S. Geological Survey (2011) and helps to characterize groundwater flow (fig. 1). Apparent groundwater-flow directions are perpendicular to potentiometric contours, but these might not be the actual flow directions because of possible anisotropic permeability resulting from cave and fracture orientations (Greene and Rahn, 1995). Anisotropic permeability can cause flow to deviate from the apparent flow direction (Freeze and Cherry, 1979). Back and others (1983) described the general groundwater flow in the Madison aquifer for the Black Hills and surrounding area, indicating that groundwater flows from the surface recharge area in the northwestern part of study area to the southwest, then sweeps east and then northeast around the southern end of the Black Hills. This description generally is consistent with the apparent flow directions indicated by the potentiometric contours shown on figure 1. These apparent flow directions provide a generalization of groundwater flow in the study area and are not necessarily accurate. A low hydraulic gradient in the area of Wind Cave, as indicated by widely spaced contours $(1,150-\mathrm{m}$ to 


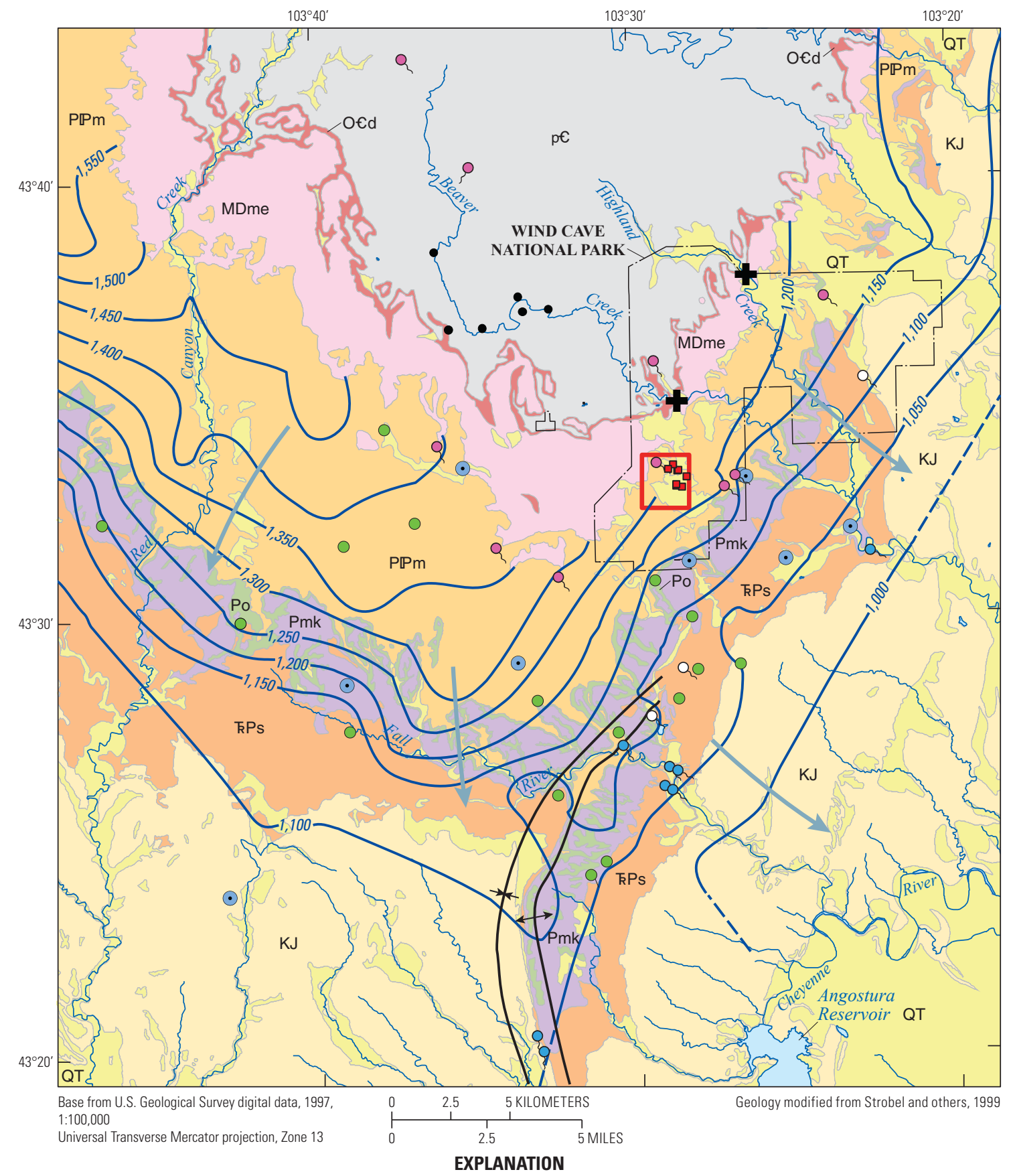

\begin{tabular}{|c|c|}
\hline & Hydrogeologic units \\
\hline QT & Quaternary-age and Tertiary-age formations \\
\hline $\mathrm{KJ}$ & Cretaceous-age and Jurassic-age formations \\
\hline kPs & Spearfish Formation \\
\hline Pmk & Minnekahta Limestone \\
\hline Po & Opeche Shale \\
\hline PPm & Minnelusa Formation \\
\hline MDme & Madison (Pahasapa) and Englewood Limestones \\
\hline O€d & Deadwood Formation \\
\hline p€ & Precambrian rocks \\
\hline
\end{tabular}

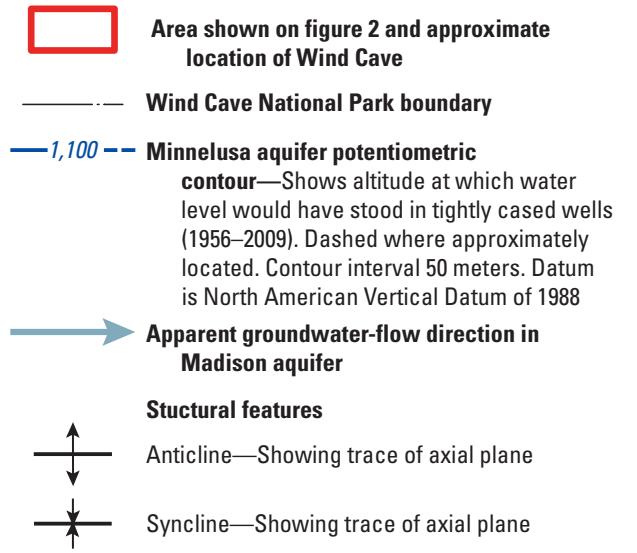

Hydrologic features

드 Stream sink

- Cave site

Springs-Tail indicates direction of flow

on Artesian spring

On Possible artesian spring

on Shallow or unknown spring type

\section{Wells}

- Minnelusa aquifer

- Madison aquifer

- Precambrian aquifer

Figure 4. Potentiometric surface of the Minnelusa aquifer. 


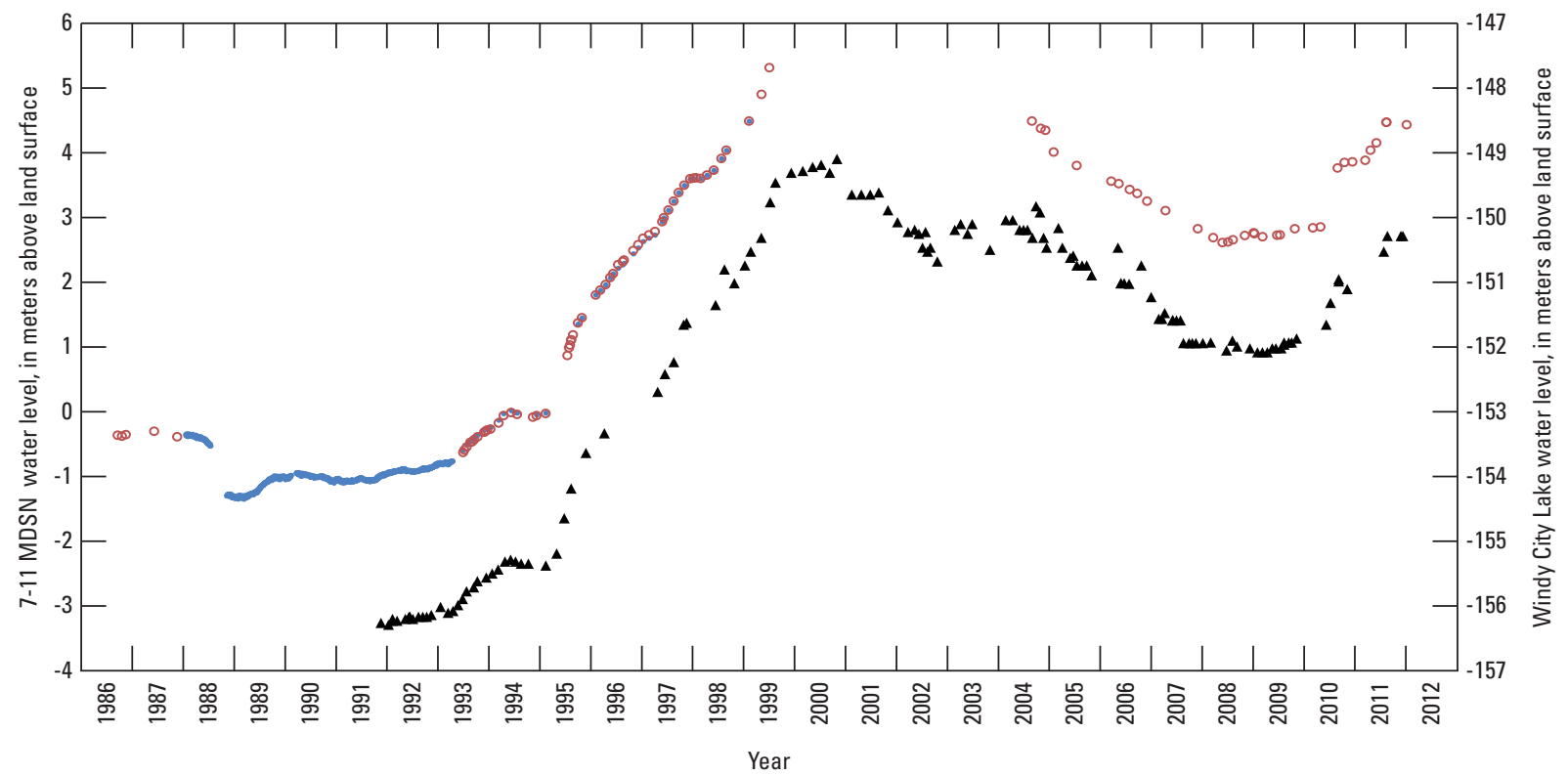

EXPLANATION

- WCL staff gage (data from Wind Cave National Park, written commun., 2011)

- WCL (U.S. Geological Survey, 2011)

- Md7-11 (data from South Dakota Department of Environment and Natural Resources written commun., 2011)

Figure 5. Water-level hydrographs for Windy City Lake (site WCL) and well Md7-11.

1,100-m contours; fig. 1), likely indicates anomalously high permeability resulting from extensive karst development.

A potentiometric-surface map of the Minnelusa aquifer also was constructed on the basis of water-level data available from the U.S. Geological Survey (2011). In general, the apparent groundwater-flow directions in the Minnelusa aquifer are similar to those in the Madison aquifer, except that in the western part of the study area the apparent flow direction is more westerly than in the Madison aquifer (figs. 1 and 4). The potentiometric surface of the Minnelusa aquifer (fig. 4) was subtracted from that of the Madison aquifer (fig. 1) to determine the direction and magnitude of the vertical hydraulic gradient (fig. 6). The resulting difference in hydraulic heads between the aquifers was used to estimate sources of spring flow. The Minnelusa aquifer has a potentiometric surface that is higher than that of the Madison aquifer within and near the outcrop of the Minnelusa Formation; farther from this outcrop, the Madison aquifer has the higher potentiometric surface (fig. 6). In places where the Madison and Minnelusa aquifers are connected hydraulically, groundwater flows from the aquifer with the higher hydraulic head into the aquifer with the lower hydraulic head. If breccia pipes are the throats of artesian springs as described by Hayes (1999), and if these throats hydraulically connect the Madison and Minnelusa aquifers, then the primary source of a spring would be the aquifer with the highest hydraulic head of the two. Artesian springs generally are located in areas where the Madison aquifer has the higher potentiometric surface of the two aquifers, which indicates that the Madison aquifer probably is the primary source of these springs.

Land-surface altitudes where Precambrian rocks are exposed generally are higher than within the outcrop of the Madison Limestone in the study area (figs. 1 and 7). Groundwater levels in the Precambrian aquifer generally are near the land surface and higher than in the Madison aquifer (U.S. Geological Survey, 2011), and this groundwater gradient indicates a possibility that groundwater might flow from the Precambrian aquifer through the Deadwood aquifer and into the Madison aquifer. Evidence for this includes apparent groundwater ages estimated from the CFC data for CFC -12 for sites CON and WTHL (table 4). The apparent age is an estimate of age where the entire sample is assumed to contain water of a single age. Well CON is located near the southwestern edge of the Madison Limestone outcrop (fig. 1) and penetrates the aquifer by about $15 \mathrm{~m}$. If not for an apparent groundwater age of 22-26 years (table 4), groundwater at this well might be assumed to represent almost entirely surface recharge because of its location. However, the apparent age indicates that a large fraction of this water did not result from recent precipitation but might have originated in the upgradient Precambrian 


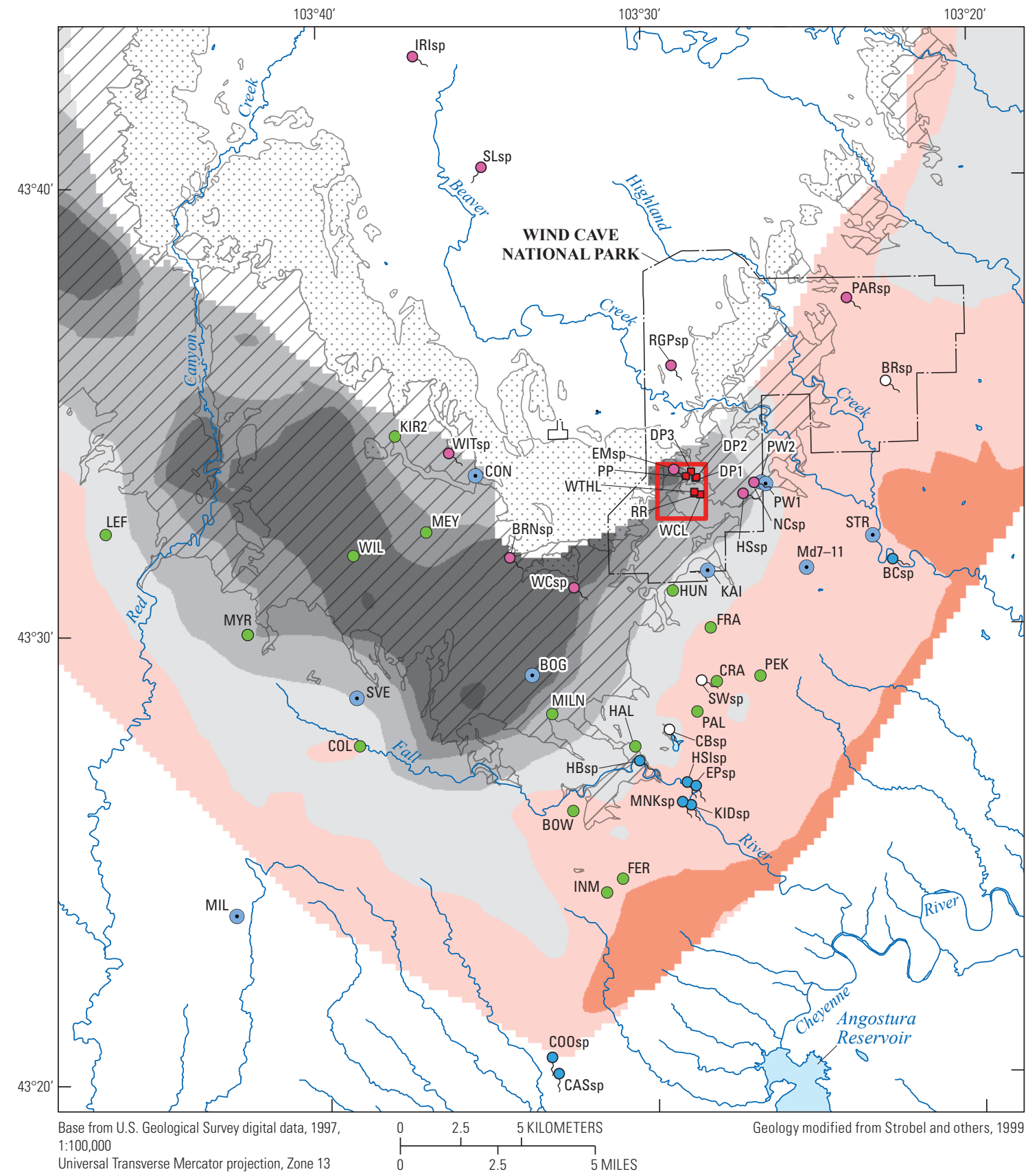

EXPLANATION

Hydraulic head difference in meters, between the Madison and Minnelusa aquifers

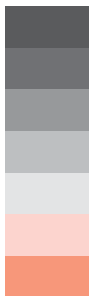

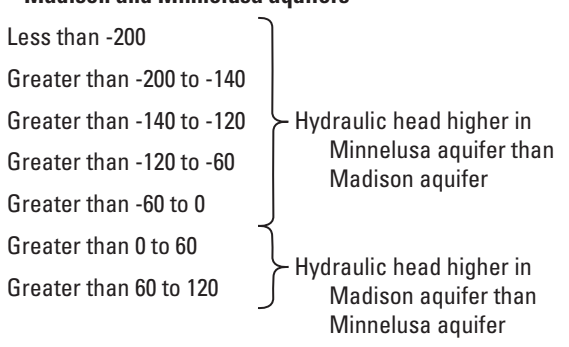

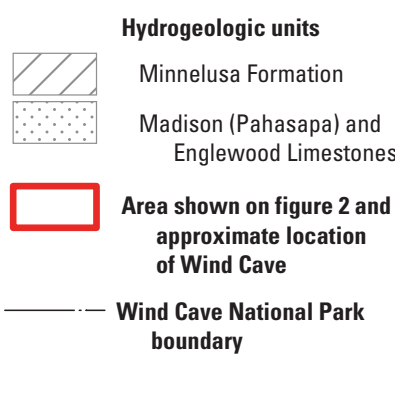

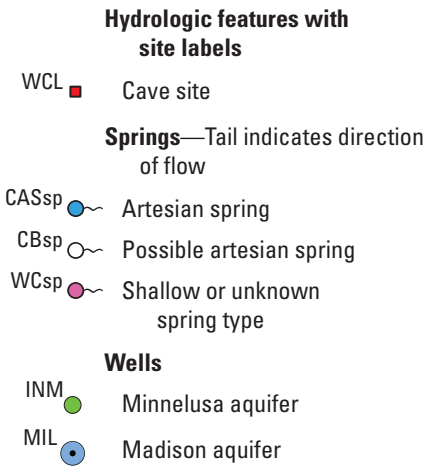

Figure 6. Difference in hydraulic head between the Madison and Minnelusa aquifers. 


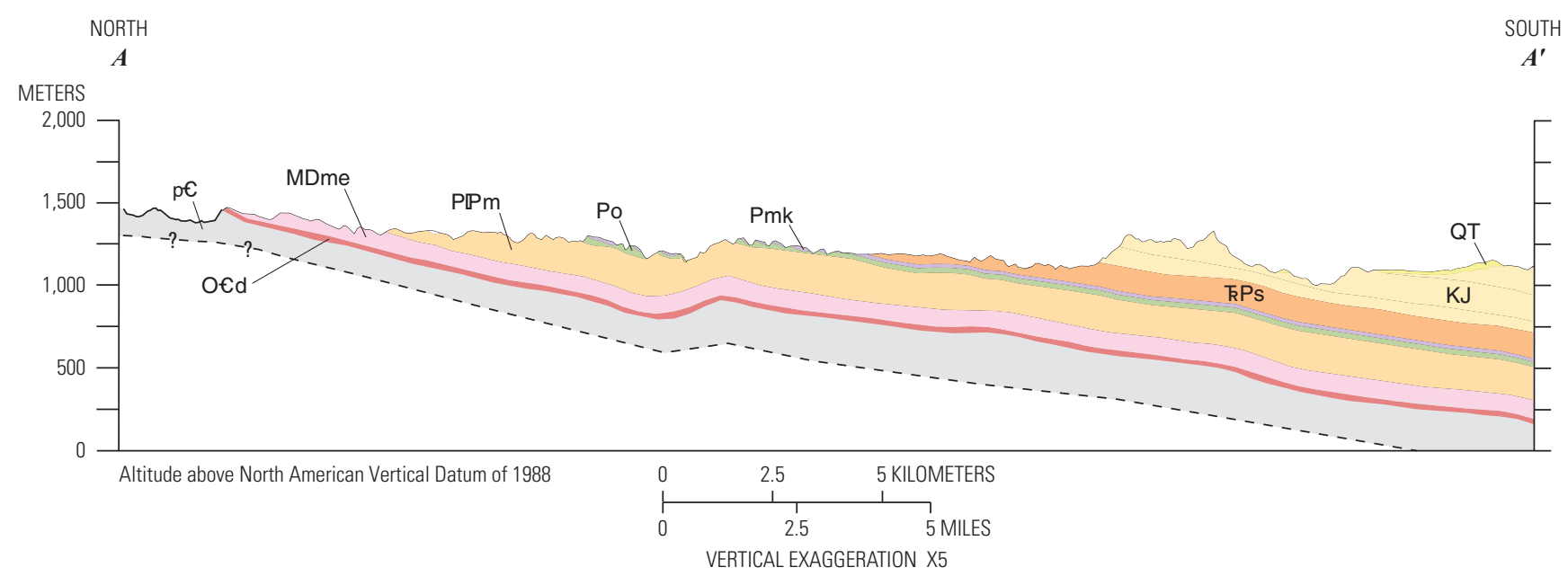

EXPLANATION

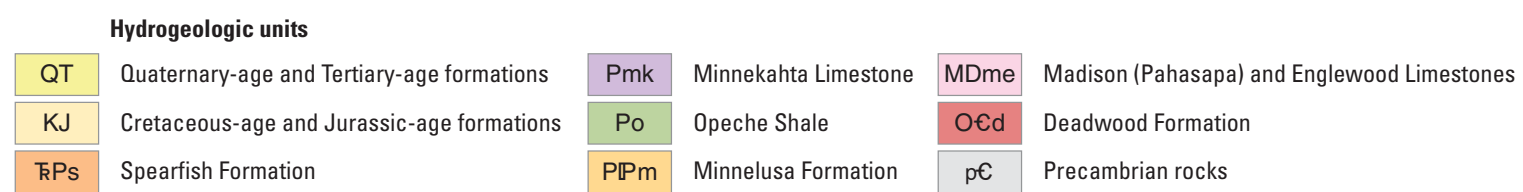

Figure 7. Geologic cross section $A-A^{\prime}$ shown on figure 1.

aquifer. Site WTHL, also located near the Madison Limestone outcrop, is a water body in Wind Cave (fig. 1) that is fed by groundwater emerging from the cave floor with an apparent age of 20-27 years (table 4), which also indicates the possible presence of water originating from the Precambrian aquifer.

\section{Dye Tracing}

Dye tracing was conducted to determine the connectivity and transit times between different groundwater sites in and near Wind Cave. Fluorescein dye was injected into What the Hell Lake (site WTHL), and charcoal dye receptors and water samples were collected and analyzed to determine the presence and concentration of dye in Rebel River (site RR; fig. 1), Windy City Lake (site WCL; fig. 1), and two wells in the park (wells PW1 and PW2; fig. 1), all of which are hydraulically downgradient from site WTHL (fig. 1). A dye receptor is a packet of charcoal, which adsorbs fluorescent dyes in water. These receptors were deployed at sites and submerged in water for at least one month. After receptors were retrieved, the dye was removed by an eluent, which was then analyzed for the presence of dye, the concentration of which is affected by the dye concentration in the water during deployment and the duration of deployment.

Wind Cave National Park staff deployed and collected the dye receptors and water samples and sent them to the Crawford Hydrology Laboratory at Western Kentucky University for analysis (table 5). The initial set of dye receptors were deployed on December 3, 2007. Dye receptors were replaced each time they were retrieved. Analyses of dye receptors and water samples were conducted at Crawford Hydrology Laboratory with a Shimadzu Model RF-5301PC Synchronously Scanning Spectrofluorophotometer, which can detect dye concentrations as low as 5 parts per trillion ( $h t t p: / /$ www.dyetracing.com). Four liters of liquid fluorescein dye (40-percent fluorescein by weight) were injected into What the Hell Lake (site WTHL) in Wind Cave on February 26, 2008. Visual dye was present in the water at WTHL and RR during a site visit on March 25, 2008. Visual dye was present in the water at WCL during a site visit on May 28, 2008.

Dye tracing indicated that groundwater reached sites WCL and RR from the injection site (WTHL) in 28 days or less (table 5). Dye was detected in every dye receptor or sample from site WCL from March 2008 to August 2011, or 42 months. Assuming a straight-line flow path from site WTHL to site WCL (265 m), which is nearly perpendicular to potentiometric contours (fig. 2), the groundwater velocity was at least 9 meters per day $(\mathrm{m} / \mathrm{d})$, but might have been faster because the first sample collected from site WCL after injection was 28 days later. Residence time for dye at site WCL and this flow path combined was at least 42 months. Residence time at site WCL alone might be shorter than 42 months because of possible groundwater retention along the flow path, which could have been a source of ongoing input to this site. The last dye receptor retrieved from site RR was 92 days after injection and had an eluent concentration that was more than 200 times higher than in eluent from any receptors retrieved from site WCL (table 5). Dye was not detected with certainty 
for any of the five samples collected from wells PW1 and PW2 (table 5).

\section{Groundwater Quality}

Hydrochemical data for samples collected from 60 sites are presented in table 12 in the "Supplemental Tables" section. Hydrochemical data presented in table 12 include $\mathrm{pH}$, specific conductance, common ions, nitrate plus nitrite, arsenic, and stable isotopes of oxygen and hydrogen. Water samples from selected sites were analyzed for trace metals, and the analytical results are presented in table 6 . The occurrence and geospatial distributions of specific conductance, nitrate plus nitrite, arsenic, and trace metals were assessed. Arsenic is a particular concern because of concentrations within the park that were higher than desirable for drinking-water quality.

\section{Specific Conductance}

Specific conductance is a measure of the electrical conductivity of water and indicates relative dissolved-solid content (Hem, 1985). The geospatial distribution of specific conductance in groundwater samples provides a general overview of water quality and hydrochemical differences in the study area. Specific conductance was interpolated between sampled sites and is shown as ranges of values in the study area (fig. 8). Specific conductance generally is lowest in recharge areas for the Madison, Minnelusa, and Precambrian aquifers and highest in the southern part of the study area, distant from recharge areas (fig. 8). The highest specific conductance values might indicate long residence times because time is required to dissolve minerals in aquifer media. A correlation between apparent groundwater age and specific conductance in the Madison aquifer exists in the Rapid City area (Long and others, 2008; South Dakota inset map on fig. 1). The southern part of the study area probably represents a mixture of groundwater that originated as surface recharge within the study area and as regional flow from the west and northwest.

\section{Arsenic}

Arsenic concentrations in samples collected for this study ranged from 0.28 to $37.1 \mathrm{mg} / \mathrm{L}$ with a median value of $6.4 \mathrm{mg} / \mathrm{L}$ (table 12), and 32 percent of these exceeded $10 \mathrm{mg} / \mathrm{L}$, which is the Maximum Contaminant Level (MCL) for drinking water in the United States (U.S. Environmental Protection Agency, 2010). The geospatial distribution of arsenic in groundwater samples for the Madison, Minnelusa, and Precambrian aquifers indicates that the highest arsenic concentrations in and near the study area are approximately coincident with the outcrop of the Minnelusa Formation as shown in figure 9, which indicates an arsenic anomaly in this area. Figure 9 was based on samples collected for this study (table 12) plus data for all other water samples available in the National Water Information System (U.S. Geological Survey, 2011). The median arsenic concentration is about equal for the Madison and Minnelusa aquifers (fig. 10). Overall, the Minnelusa aquifer has slightly larger arsenic concentrations than the Madison aquifer (fig. 10). Where sampling sites for the Madison and Minnelusa aquifers are proximal, arsenic concentrations generally are similar (fig. 9), so the concentration differences indicated by figure 10 might result partly from geospatial differences in sample locations between the two aquifers.

The exceptions to the association of arsenic with the outcrop of the Minnelusa Formation are samples from two wells open to the Precambrian aquifer (well MOR and WOO; fig. 9), which had arsenic concentrations of 35.2 and $12.7 \mathrm{mg} / \mathrm{L}$, respectively. These concentrations, which are high relative to other Precambrian aquifer samples, might be the result of previous industrial activities in the town of Pringle (located at well MOR), which were the focus of U.S. Environmental Protection Agency (USEPA) investigations from 1991 to 2001 (Hayhurst, 2002), and included wood preservative treatment with chromated copper arsenate. Soil in the Pringle area was contaminated with arsenic, chromium, copper, zinc, pentachlorophenol, polycyclic aromatic hydrocarbons, dioxins, and furans. Dioxins and furans were detected in Beaver Creek and its sediments downstream from the former industrial site, with decreasing concentrations in a downstream direction (Hayhurst, 2002). Heakin (2004) documented the presence of phenol in Beaver Creek in 2002 and 2003 in the park and about $2 \mathrm{~km}$ upstream from the western park boundary.

The arsenic anomaly coincident with the outcrop of the Minnelusa Formation also exists when all groundwater and surface-water samples available from the National Water Information System (U.S. Geological Survey, 2011) in and near the study area are plotted (fig. 11). The area shown in figure 11 extends beyond the study area to show a larger representation of the arsenic anomaly and indicates that the Minnelusa and Madison aquifers have the highest arsenic concentrations when compared with other groundwater and surface-water sites in and near the southern Black Hills.

The geographic association of the arsenic anomaly with the Minnelusa Formation outcrop (excluding the Pringle area) indicates that arsenic in groundwater probably results from naturally occurring minerals in the marine shales of this formation. Marine shales commonly contain high concentrations of arsenic, which is released into the aqueous phase in aquifers as a result of oxidative weathering of iron-sulfide minerals, mainly pyrite $\left(\mathrm{FeS}_{2}\right)$ and arsenopyrite (FeAsS; Muloin and Dudas, 2005). During sulfide mineral formation, arsenic precipitates with iron and sulfide and is incorporated into the mineral structure (Muloin and Dudas, 2005). Zhu and others (2008) concluded that microbial sulfide production enhances arsenic mobilization in pyrite-bearing black shale formations. Solid-phase arsenic concentration was analyzed in clay, sand and gravel, shales, and limestones in aquifers of the Lower Illinois River Basin (not shown in report), where arsenic concentrations in groundwater were as high as $110 \mathrm{mg} / \mathrm{L}$, and the highest solid-phase concentrations were in shales (Warner, 2001). This author concluded that dark shales in the bedrock 
Table 4. Chlorofluorocarbon (CFC) and tritium data.

[n, number of CFC samples; pptv, parts per trillion by volume; pCi/L, picocuries per liter, --, could not be estimated by this method]

\begin{tabular}{|c|c|c|c|c|c|c|c|c|c|c|c|c|c|c|c|c|c|c|c|c|c|}
\hline \multirow[b]{2}{*}{$\begin{array}{c}\text { Site } \\
\text { name }\end{array}$} & \multirow[b]{2}{*}{ Station number } & \multirow[b]{2}{*}{ Station name } & \multirow[b]{2}{*}{ Date } & \multirow[b]{2}{*}{$n$} & \multicolumn{3}{|c|}{$\begin{array}{l}\text { Calculated atmospheric mixing } \\
\text { ratio, in pptva }\end{array}$} & \multicolumn{3}{|c|}{$\begin{array}{c}\text { Apparent groundwater age, } \\
\text { in years }\end{array}$} & \multicolumn{9}{|c|}{ Results of binary mixing model ${ }^{b}$} & \multirow[b]{2}{*}{$\begin{array}{l}\text { Tritium, } \\
\text { in pCi/L }\end{array}$} & \multirow[b]{2}{*}{$\begin{array}{l}\text { Tritium, } \\
\text { 2-sigma, } \\
\text { in pCi/l }\end{array}$} \\
\hline & & & & & CFC- 11 & CFC-12 & CFC- 113 & CFC-11 & CFC-12 & CFC-113 & $\begin{array}{l}\text { CFC-11/CFC- } \\
12 \text { ratio age, } \\
\text { in years }\end{array}$ & $\begin{array}{c}\text { Percent } \\
\text { young } \\
\text { water in } \\
\text { mixture }{ }^{\mathrm{a}, \mathrm{c}}\end{array}$ & $\begin{array}{c}\text { Number } \\
\text { of samples } \\
\text { used }\end{array}$ & $\begin{array}{l}\text { CFC-113/ } \\
\text { CFC-12 } \\
\text { ratio age, } \\
\text { in years }\end{array}$ & $\begin{array}{c}\text { Percent } \\
\text { young } \\
\text { water in } \\
\text { mixture }{ }^{a, c}\end{array}$ & $\begin{array}{l}\text { Number } \\
\text { of samples } \\
\text { used }\end{array}$ & $\begin{array}{l}\text { CFC-11/ } \\
\text { CFC-11 } \\
\text { ratio age, } \\
\text { in years }\end{array}$ & $\begin{array}{l}\text { Percent } \\
\text { young } \\
\text { water in } \\
\text { mixturea,c }\end{array}$ & $\begin{array}{l}\text { Number of } \\
\text { samples } \\
\text { used }\end{array}$ & & \\
\hline \multicolumn{11}{|c|}{ Stream sink site } & \multicolumn{11}{|c|}{ Stream sink site } \\
\hline $\mathrm{BevCr}$ & 06402430 & $\begin{array}{c}\text { Beaver Creek near } \\
\text { Pringle, S. Dak. }\end{array}$ & 04/16/2007 & 0 & -- & -- & -- & -- & -- & -- & -- & -- & -- & -- & -- & -- & -- & -- & -- & 50.2 & 3.0 \\
\hline \multicolumn{11}{|c|}{ Cave drip site } & \multicolumn{11}{|c|}{ Cave drip site } \\
\hline DP3 & 433302103281509 & 6S 5E12DBAB9 & 04/25/2007 & 0 & -- & -- & -- & -- & -- & -- & -- & -- & -- & -- & -- & -- & -- & -- & -- & 29.4 & 1.9 \\
\hline \multicolumn{11}{|c|}{ Cave water body sites } & \multicolumn{11}{|c|}{ Cave water body sites } \\
\hline WTHL & 433302103281502 & 6S 5E12DBAB2 & 04/18/2007 & 2 & 196.8 & 439.8 & 55.0 & 24 & 20 & 20 & -- & -- & -- & -- & -- & -- & 18 & 72 & 2 & 15.7 & 1.3 \\
\hline WTHL & 433302103281502 & 6S 5E12DBAB2 & 07/16/2009 & 2 & 190.3 & 445.2 & 53.0 & 27 & 23 & 23 & -- & -- & -- & -- & -- & -- & 20 & 75 & 2 & -- & -- \\
\hline \multicolumn{11}{|c|}{ Artesian spring sites } & \multicolumn{11}{|c|}{ Artesian spring sites } \\
\hline HBsp & 432703103302801 & 7S 5E10DCBA & 04/20/2007 & 2 & 44.3 & 107.3 & 12.3 & 39 & 39 & 32 & -- & -- & -- & 22 & 26 & 2 & 15 & 68 & 2 & 3.8 & 1.0 \\
\hline HBsp & 432703103302801 & 7S 5E10DCBA & 05/28/2009 & 2 & 35.5 & 104.9 & 11.1 & 43 & 41 & 35 & -- & -- & -- & 25 & 28 & 2 & 15 & 13 & 2 & 5.7 & -- \\
\hline BCsp & 433128103223401 & $6 \mathrm{~S} 6 \mathrm{E} 14 \mathrm{CDB}$ & 04/17/2007 & 3 & 31.9 & 82.7 & 10.3 & 41 & 41 & 33 & -- & -- & -- & 21 & 20 & 3 & 19 & 63 & 2 & 4.5 & 1.0 \\
\hline BCsp & 433128103223401 & 6S 6E14CDB & 05/28/2009 & 2 & 30.2 & 91.7 & 8.6 & 44 & 42 & 37 & -- & -- & -- & 26 & 25 & 2 & 20 & 12 & 2 & 6.0 & -- \\
\hline CASsp & 432006103330501 & 8S 5E20CDAB & 06/19/2009 & 3 & 24.6 & 60.6 & 6.9 & 45 & 46 & 38 & 38 & 36 & 2 & 24 & 15 & 3 & 20 & 10 & 3 & 4.0 & -- \\
\hline COOsp & 432028103331601 & 8S 5E20BDCB & 06/19/2009 & 3 & 38.4 & 103.9 & 13.0 & 42 & 41 & 34 & 41 & 89 & 1 & 22 & 25 & 3 & 12 & 15 & 1 & 3.9 & -- \\
\hline HSIsp & 432632103285302 & 7S 5E14DDDA & 05/21/2009 & 2 & 42.2 & 157.5 & 11.8 & 42 & 38 & 34 & -- & -- & -- & 29 & 52 & 2 & 20 & 16 & 2 & -- & -- \\
\hline KIDsp & 432605103285401 & 7S 5E14DDD & 06/19/2009 & 3 & 28.8 & 169.9 & 13.0 & 44 & 37 & 34 & -- & -- & -- & 29 & 55 & 3 & -- & -- & -- & .9 & -- \\
\hline MIL & 432340103421501 & 7S 3E36CBDC & 04/08/2010 & 3 & 21.0 & 3.1 & .0 & 47 & 64 & 57 & -- & -- & -- & -- & -- & -- & -- & -- & -- & -- & -- \\
\hline MNKsp & 432605103290901 & 7S 5E14DCD & 05/28/2009 & 2 & 25.6 & 171.3 & 3.4 & 45 & 37 & 44 & -- & -- & -- & -- & -- & -- & 30 & 16 & 2 & .5 & -- \\
\hline \multicolumn{11}{|c|}{ Well sites } & \multicolumn{11}{|c|}{ Well sites } \\
\hline HUN & 433034103284701 & 6S 5E23DB & 04/17/2007 & 3 & 129.4 & 283.2 & 35.6 & 31 & 29 & 24 & -- & -- & -- & 20 & 67 & 3 & 18 & 71 & 3 & 26.9 & 1.9 \\
\hline BOG & 432858103334201 & 6S 5E31DA & 04/26/2007 & 3 & 96.5 & 170.2 & 23.9 & 34 & 35 & 27 & 30 & 66 & 1 & 19 & 37 & 3 & 18 & 63 & 3 & 1.6 & 1.0 \\
\hline BOG & 432858103334201 & 6S 5E31DA & 07/15/2009 & 3 & 28.7 & 99.3 & 9.4 & 44 & 42 & 36 & -- & -- & -- & 26 & 28 & 3 & 13 & 11 & 2 & .6 & -- \\
\hline CON & 433326103352001 & 6S 4E 1DB & 07/15/2009 & 3 & 220.7 & 388.0 & 61.7 & 24 & 26 & 22 & -- & -- & -- & 18 & 76 & 2 & 20 & 86 & 3 & 29.3 & -- \\
\hline $\operatorname{Md} 7-11^{d}$ & 433115103251401 & $\begin{array}{l}\text { 6S 6E21BBBB } \\
\text { (CU91A) }\end{array}$ & 04/20/2007 & 2 & 4.6 & 3.0 & .0 & 52 & 61 & 54 & -- & -- & -- & -- & -- & -- & -- & -- & -- & .6 & .6 \\
\hline PW1 & 433311103263101 & 6S 6E 6DDA & 07/29/2009 & 2 & 147.3 & 316.1 & 38.3 & 32 & 29 & 26 & -- & -- & -- & 23 & 77 & 2 & 21 & -- & 2 & 21.4 & -- \\
\hline PW2 & 433311103263102 & 6S 6E 6DDA2 & 07/29/2009 & 3 & 182.3 & 115.8 & 13.7 & 27 & 41 & 34 & -- & -- & -- & 24 & 29 & 3 & 21 & 20 & 1 & 9.2 & -- \\
\hline STR & 433150103230501 & 6S 6E15ABDD & 04/17/2007 & 3 & 70.6 & 152.5 & 17.9 & 36 & 36 & 29 & 36 & 97 & 1 & 21 & 38 & 3 & 19 & 62 & 3 & 16.6 & 1.3 \\
\hline STR & 433150103230501 & 6S 6E15ABDD & 05/22/2009 & 2 & 66.0 & 162.2 & 19.3 & 39 & 38 & 31 & -- & -- & -- & 23 & 40 & 2 & 19 & 25 & 2 & 17.4 & -- \\
\hline SVE & 432825103391201 & $7 \mathrm{~S} 4 \mathrm{E} 4 \mathrm{BAC}$ & 09/02/2009 & 3 & 191.6 & 80.4 & 8.2 & 27 & 44 & 38 & -- & -- & -- & 26 & 21 & 3 & -- & -- & -- & 3.4 & -- \\
\hline
\end{tabular}

"Average of multiple samples. Age is the apparent age of the young fraction

Plummer and Busenberg (2000).

'Percentage younger than about 60 years.

${ }^{\mathrm{d}}$ Methane present. Apparent ages represents the minimum apparent age. 
aquifer were the likely source of arsenic in the overlying and adjacent glacial drift aquifer. In groundwater of the Piedmont Province of Pennsylvania (not shown in report), arsenic concentrations higher than $10 \mathrm{mg} / \mathrm{L}$ were the result of arsenic mobilization from shales, whereas the arsenic concentrations in the pore water of igneous, crystalline, and calcareous rocks typically were lower (Serfes and others, 2006; Peters and Burkert, 2008; Rhine and others, 2008).

It is most likely that arsenic in the Minnelusa and Madison aquifers originates in shale layers of the Minnelusa aquifer and is transported downward into the Madison aquifer by advective flow. This is possible in areas where the hydraulic head in the Minnelusa aquifer is higher than in the Madison aquifer (fig. 6), which also is approximately coincident with the arsenic anomaly (fig. 9). This downward seepage is known to occur in the area of Wind Cave, where groundwater in the unsaturated zone of the Minnelusa aquifer seeps downward into the Madison aquifer and drips from the ceiling of the cave at numerous locations. Arsenic concentrations in sampled drip water (table 12) ranged from 24.3 to $34.2 \mathrm{mg} / \mathrm{L}$ (sites DP1, DP2, and DP3) and from 12.6 to $16.4 \mathrm{mg} / \mathrm{L}$ for water bodies in the cave (sites WCL, WTHL, PP, and RR). This indicates that arsenic concentrations in Wind Cave were highest for water that is known to originate in the Minnelusa aquifer. Cave drip probably contributes to cave water bodies, which also may receive contributions from the Precambrian aquifer as previously described in the "Groundwater Gradients and Flow Directions" section. If so, this would result in a mixture in the cave water bodies of groundwater from the Minnelusa aquifer (cave drip) and the Precambrian aquifer. The sampling site closest to the cave for the Precambrian aquifer was a spring (RGPsp; fig. 1), which had an arsenic concentration of $2.0 \mathrm{mg} / \mathrm{L}$ (table 12). Therefore, mixing could have affected the observed arsenic concentrations in the cave water bodies, which had concentrations between those of cave drip and the Precambrian aquifer.

It is uncertain why the arsenic anomaly is coincident with the Minnelusa Formation outcrop rather than confined aquifer areas, but might be related to weathering of shales in the outcrop. As Muloin and Dudas (2005) stated, weathering of marine shales releases arsenic into groundwater. Further, as described by Tuttle and others (2009), during oxidative weathering of iron-sulfide minerals in marine shales, arsenic and other trace elements are dispersed or redistributed in the environment by aqueous and mechanical transport. The decrease in arsenic concentration downgradient from the outcrop areas of the Minnelusa and Madison Formations indicates that mobilized arsenic is not transported large distances in the Minnelusa and Madison aquifers. The reason for this is unclear, and arsenic concentrations did not correlate with either $\mathrm{pH}$ or dissolved oxygen. It is possible that dissolved arsenic originates from particular shale layers in the Minnelusa Formation,

Table 5. Results of laboratory analyses of the presence of fluorescein dye in charcoal dye receptors that were placed in Wind Cave water bodies and two wells. Dye was injected on February 26, 2008.

[ppb, parts per billion; B, background concentration; --, no sample; ND, nondetection]

\begin{tabular}{|c|c|c|c|c|c|c|c|}
\hline \multirow[b]{2}{*}{ Date collected } & \multirow[b]{2}{*}{$\begin{array}{c}\text { Days since } \\
\text { injection }\end{array}$} & \multirow[b]{2}{*}{$\begin{array}{c}\text { Years since } \\
\text { injection }\end{array}$} & \multicolumn{2}{|c|}{ Windy City Lake (WCL) } & \multirow{2}{*}{$\begin{array}{c}\text { Rebel River } \\
\text { (RR), } \\
\text { in ppb }\end{array}$} & \multirow[b]{2}{*}{ Well PW1 } & \multirow[b]{2}{*}{ Well PW2 } \\
\hline & & & $\begin{array}{l}\text { Dye receptor eluent, } \\
\text { in ppb }\end{array}$ & $\begin{array}{l}\text { Water sample, } \\
\text { in ppb }\end{array}$ & & & \\
\hline $02 / 26 / 2008$ & 0 & 0.0 & B & -- & ND & -- & -- \\
\hline $03 / 20 / 2008$ & 23 & .1 & -- & -- & -- & ND & ND \\
\hline $03 / 25 / 2008$ & 28 & .1 & 0.85 & -- & 249,000 & -- & -- \\
\hline $05 / 28 / 2008$ & 92 & .3 & 59.4 & -- & 93,000 & -- & -- \\
\hline $07 / 09 / 2008$ & 134 & .4 & 168 & -- & -- & -- & -- \\
\hline 08/04/2008 & 160 & .4 & -- & -- & -- & B & ND \\
\hline $09 / 11 / 2008$ & 198 & .5 & -- & -- & -- & -- & ND \\
\hline $11 / 13 / 2008$ & 261 & .7 & 376 & -- & -- & -- & -- \\
\hline 01/07/2009 & 316 & .9 & 96.3 & -- & -- & -- & -- \\
\hline 06/30/2009 & 490 & 1.3 & -- & -- & -- & -- & B \\
\hline $05 / 03 / 2010$ & 797 & 2.2 & 302 & -- & -- & -- & -- \\
\hline $07 / 16 / 2010$ & 871 & 2.4 & 261 & -- & -- & -- & -- \\
\hline $04 / 25 / 2011$ & 1,154 & 3.2 & -- & .52 & -- & -- & -- \\
\hline $06 / 08 / 2011$ & 1,198 & 3.3 & 21.4 & -- & -- & -- & -- \\
\hline 08/18/2011 & 1,269 & 3.5 & 101.5 & -- & -- & -- & -- \\
\hline
\end{tabular}


Table 6. Trace-metal data for water samples from selected sites within Wind Cave National Park.

$\left[\mu \mathrm{g} / \mathrm{L}\right.$, micrograms per liter; $\mu \mathrm{S} / \mathrm{cm}$, microsiemens per centimeter at 25 degrees Celsius; $<$, less than; E, estimated value $\mathrm{a}^{\mathrm{a}}$--, not applicable]

\begin{tabular}{|c|c|c|c|c|c|c|c|c|c|c|}
\hline Site name & Station number & Station name & Date & $\begin{array}{c}\text { Arsenic, } \\
\text { dissolved } \\
(\mu \mathrm{g} / \mathrm{L})\end{array}$ & $\begin{array}{c}\text { Chromium, } \\
\text { dissolved } \\
(\mu \mathrm{g} / \mathrm{L})\end{array}$ & $\begin{array}{c}\text { Copper, } \\
\text { dissolved } \\
\text { ( } \mu \mathrm{g} / \mathrm{L})\end{array}$ & $\begin{array}{c}\text { Lithium, } \\
\text { dissolved } \\
\text { ( } \mu \mathrm{g} / \mathrm{L})\end{array}$ & $\begin{array}{c}\text { Vanadium, } \\
\text { dissolved } \\
(\mu \mathrm{g} / \mathrm{L})\end{array}$ & $\begin{array}{c}\text { Zinc, } \\
\text { dissolved } \\
(\mu \mathrm{g} / \mathrm{L})\end{array}$ & $\begin{array}{c}\text { Specific } \\
\text { conductance, } \\
\text { unfiltered }(\mu \mathrm{S} / \\
\mathrm{cm})\end{array}$ \\
\hline \multicolumn{11}{|c|}{ Stream sink site } \\
\hline $\mathrm{BevCr}$ & 06402430 & $\begin{array}{r}\text { Beaver Creek near } \\
\text { Pringle, S. Dak. }\end{array}$ & $06 / 25 / 2008$ & 4.4 & $<0.12$ & $<1$ & 34 & 2.7 & $<1.8$ & 563 \\
\hline \multicolumn{11}{|c|}{ Cave drip sites } \\
\hline DP2 & 433302103281508 & 6S 5E12DBAB8 & $06 / 26 / 2008$ & 24.4 & 0.12 & Е 0.99 & 6 & 6.6 & $<1.8$ & 360 \\
\hline DP3 & 433302103281509 & 6S 5E12DBAB9 & $06 / 26 / 2008$ & 23.8 & $<.12$ & E. .54 & 2 & 6.5 & E 1.1 & 263 \\
\hline \multicolumn{11}{|c|}{ Artesian spring site } \\
\hline BRsp & 433525103224401 & 5S 6E26BBCD & $06 / 25 / 2008$ & 5.6 & 0.38 & 2.4 & 422 & 19.6 & $<3.6$ & 2,830 \\
\hline \multicolumn{11}{|c|}{ Shallow spring sites } \\
\hline PARsp & 433717103235401 & 5S 6E15BBAC & $06 / 25 / 2008$ & 12.2 & 0.12 & 1.5 & 28 & 6.4 & 2.4 & 472 \\
\hline Emsp & 433332103291801 & 6S 5E 2ACBD & $06 / 25 / 2008$ & 12 & E. 08 & 1.1 & 10 & 16.6 & 16.6 & 605 \\
\hline HSsp & 433258103270801 & 6S 6E 7BAAC & $06 / 26 / 2008$ & 25.9 & E.07 & 1.6 & 7 & 4.4 & $<1.8$ & 390 \\
\hline NCsp & 433312103264701 & 6S 6E 6DCAA & $06 / 26 / 2008$ & 16.7 & $<.12$ & E.92 & 7 & 6 & E 1.2 & 408 \\
\hline NCsp & 433312103264701 & 6S 6E 6DCAA & $06 / 26 / 2008$ & 16.7 & $<.12$ & E. .57 & 7 & 6 & 1.8 & 408 \\
\hline RGPsp & 433551103291901 & 5S 5E23DBCD & $06 / 25 / 2008$ & 1.7 & $<.12$ & $<1$ & 37 & .72 & 4 & 363 \\
\hline \multicolumn{4}{|c|}{ Maximum Contaminant Level (MCL), in $\mu \mathrm{g} / \mathrm{L}^{\mathrm{b}}$} & 10 & 100 & 1,300 & -- & -- & -- & -- \\
\hline
\end{tabular}

${ }^{a}$ Value less than the lowest calibration standard (Childress and others, 1999).

${ }^{\mathrm{b}}$ From U.S. Environmental Protection Agency (2010). 


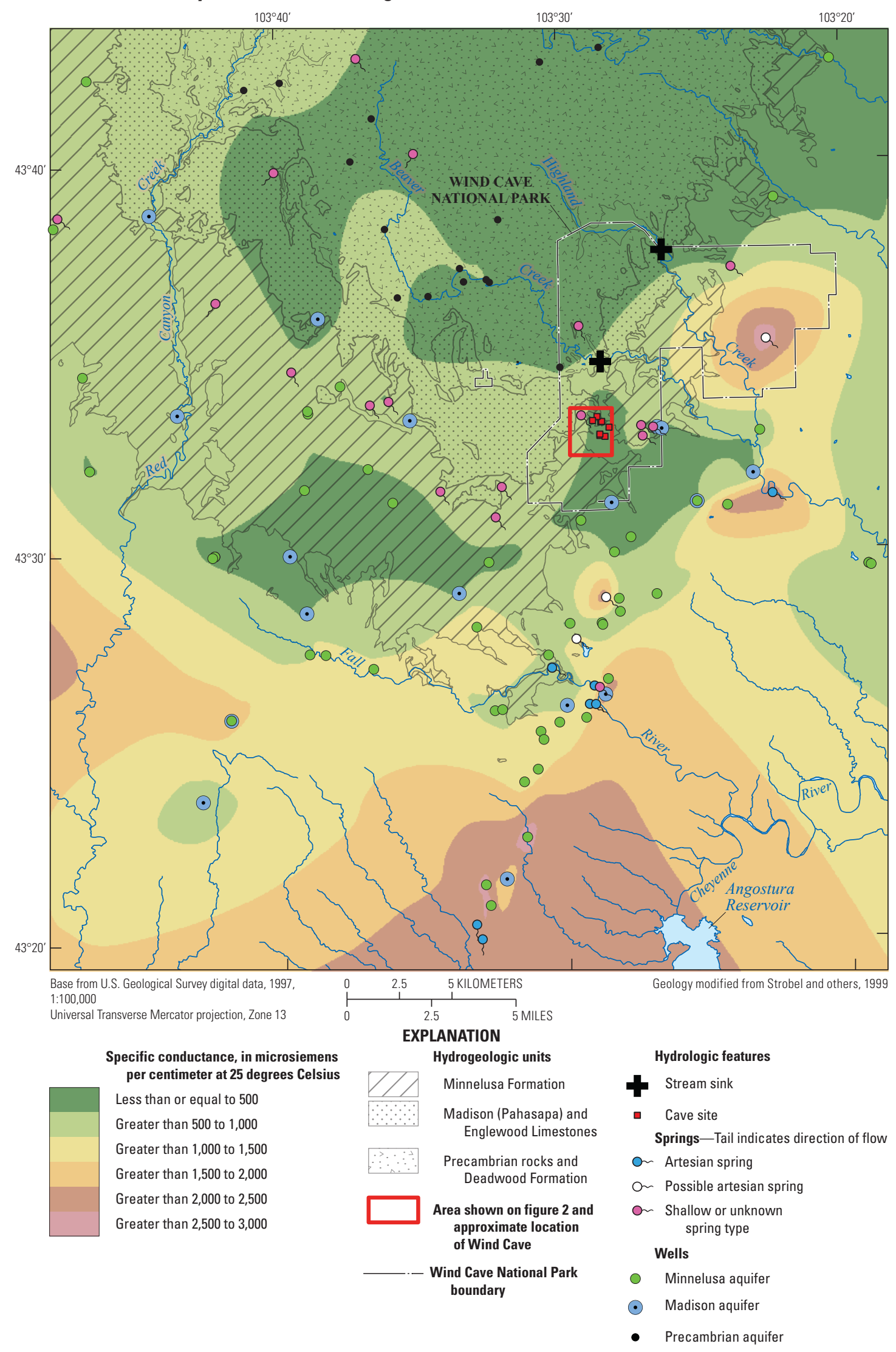

Figure 8. Geospatial distribution of specific conductance for the Minnelusa, Madison, and Precambrian aquifers in the study area. (All relevant sites with specific conductance data available from the National Water Information System [U.S. Geological Survey, 2011] are included in map.) 


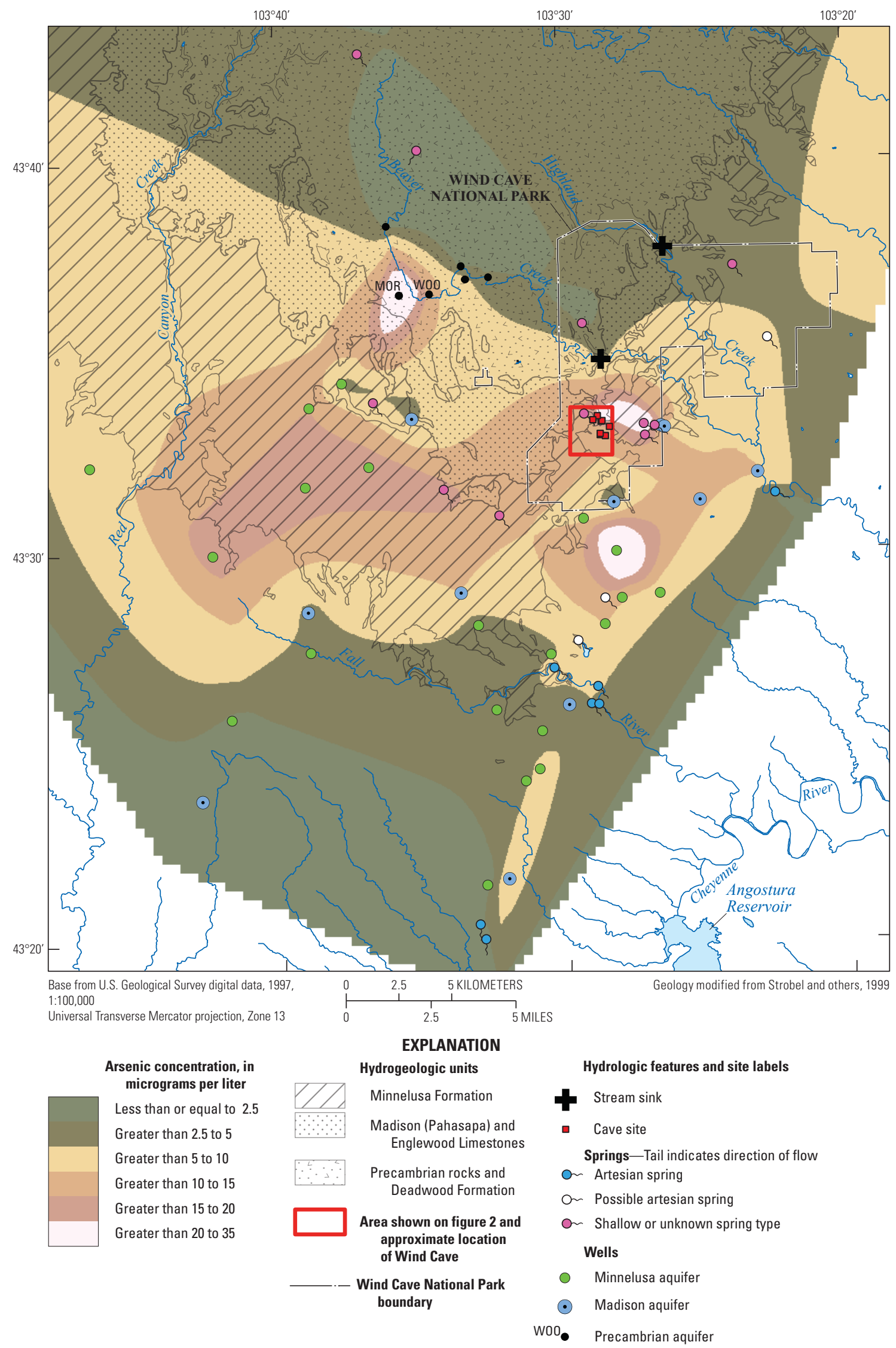

Figure 9. Geospatial distribution of arsenic concentrations for the Minnelusa, Madison, and Precambrian aquifers in the study area. (All relevant sites with arsenic data available from the National Water Information System [U.S. Geological Survey, 2011] are included in map.) 

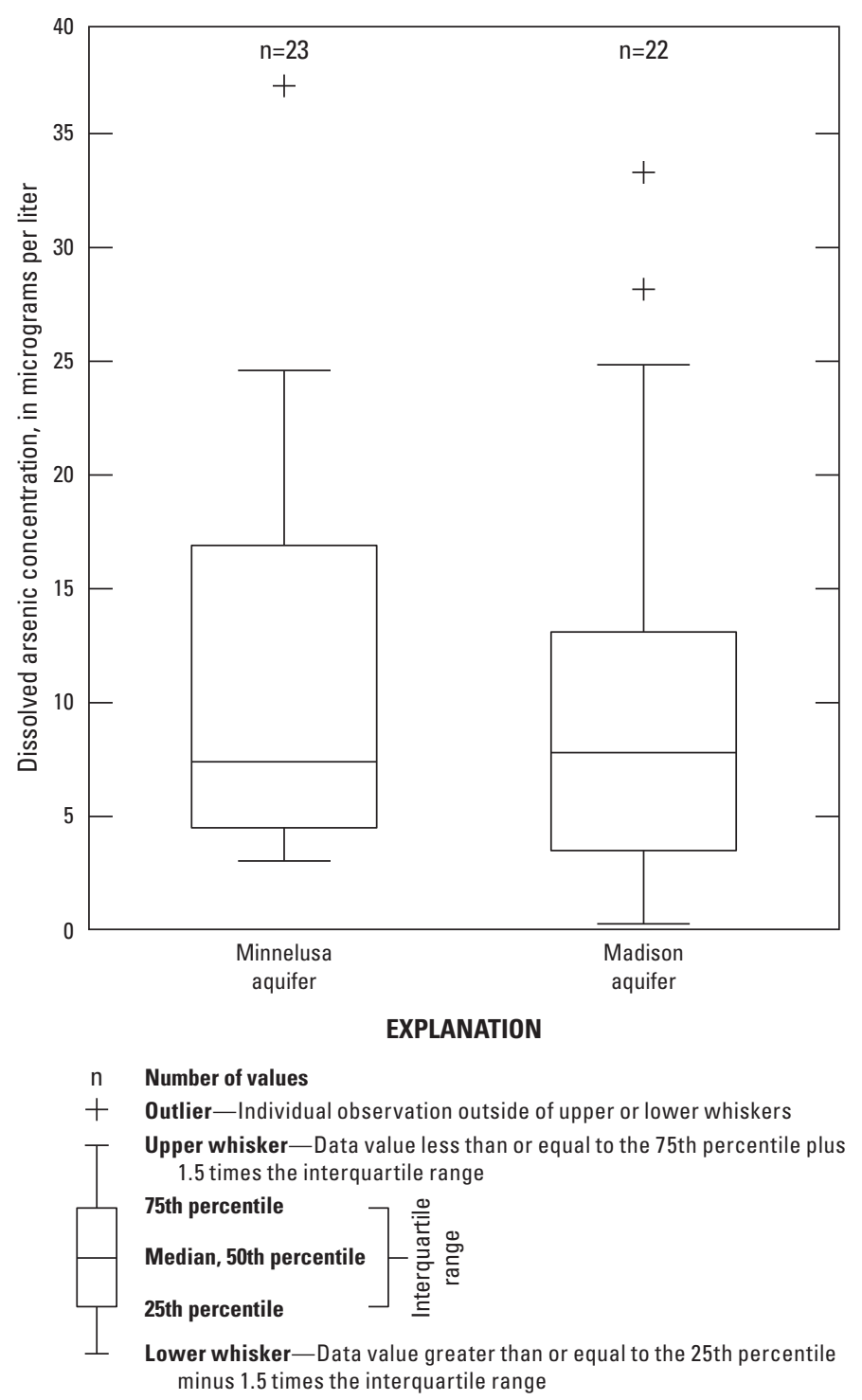

Figure 10. Boxplots of arsenic concentrations in the Minnelusa and Madison aquifers.

which was assessed by considering a possible correlation between arsenic concentrations and the sampling depth from the top of the Minnelusa aquifer; however, no such correlation is apparent on a scatter plot (fig. 12).

\section{Nitrate Plus Nitrite}

Potential sources of nitrate in groundwater include nitrogen fertilizer, mining, landfills, atmospheric deposition, and human or animal waste (Meyer, 1987; Taylor, 2003; Katz, 2004; Rahn, 2006). Concentrations of nitrate plus nitrite in samples collected for this study are presented in table 12 and were less than 2 milligrams per liter ( $\mathrm{mg} / \mathrm{L}$ ) for 92 percent of these samples and ranged from 0.13 to $2.38 \mathrm{mg} / \mathrm{L}$. Concentrations in this range are not a concern for drinking-water quality because the MCL for nitrate drinking water is $10 \mathrm{mg} / \mathrm{L}$ (U.S. Environmental Protection Agency, 2010). The area with the highest nitrate plus nitrite concentrations is on the western side of the outcrop areas of the Madison and Minnelusa aquifers with concentrations decreasing to the south and east (fig. 13). The reason for this geospatial distribution is unclear and unaccounted for by land-use differences. Grazing of domestic stock occurs in many areas outside of Wind Cave National Park, and wildlife grazing occurs inside the park. Wind Cave National Park monitors nitrate concentrations in precipitation for the park and reports a 10-year average of $1.4 \mathrm{mg} / \mathrm{L}$ (Wind Cave National Park, written commun., 2011).

Site WCL in Wind Cave had a concentration of nitrate plus nitrite of $2.38 \mathrm{mg} / \mathrm{L}$, which is not visible in the interpolated shaded areas on figure 13 because other proximal cave sites had lower concentrations ranging from 0.5 to $1.6 \mathrm{mg} / \mathrm{L}$. Cave sites had a median concentration of $1.3 \mathrm{mg} / \mathrm{L}$, and other sampled sites in the park had a median concentration of $0.2 \mathrm{mg} / \mathrm{L}$. The two wells within the park (sites PW1 and PW2) had concentrations of 0.6 and $0.2 \mathrm{mg} / \mathrm{L}$, respectively.

\section{Trace Metals}

Exploratory sampling of trace metals (chromium, copper, lithium, vanadium, and zinc) for selected sites in the park was conducted to assess possible existence of unusually high concentrations or correlations of these metals with arsenic. The USEPA regulates arsenic, chromium, and copper with MCLs of 10, 100, and 1,300 $\mu \mathrm{g} / \mathrm{L}$, respectively (U.S. Environmental Protection Agency, 2010). The highest concentrations for chromium and copper were 0.38 and $2.4 \mu \mathrm{g} / \mathrm{L}$, respectively, or less than 1 percent of the MCL (table 6). The concentration of lithium for spring BRsp was $422 \mu \mathrm{g} / \mathrm{L}$, which was much higher than the other sites, and specific conductance for this site also was much higher than the other sites (table 6). Although the USEPA has not set an MCL for drinking water for lithium, it can be toxic to plants. For example, injury to some crops from lithium in irrigation water occurred at concentrations as low as $50 \mu \mathrm{g} / \mathrm{L}$, but in other cases, injury was not observed at concentrations lower than 5,000 $\mu \mathrm{g} / \mathrm{L}$ (Bingham and others, 1964). Lithium concentrations of 600 micrograms per gram $(\mu \mathrm{g} / \mathrm{g})$ in the leaves of Bush bean plants resulted in severe toxicity, and lithium accumulates in plant tissue (Wallace and others, 1977). Based on all samples collected in the park, arsenic indicated no apparent correlation with any of the five other trace metals when observed on scatter plots. Because of the generally low concentrations of trace metals and the lack of correlation with arsenic, additional sampling was not conducted.

\section{Groundwater Mixing}

All variables used in PCA were log transformed, which resulted in datasets that approximated normal distributions, and all variables were then standardized to a mean of zero and standard deviation of one. Stable-isotope values (table 12), all 


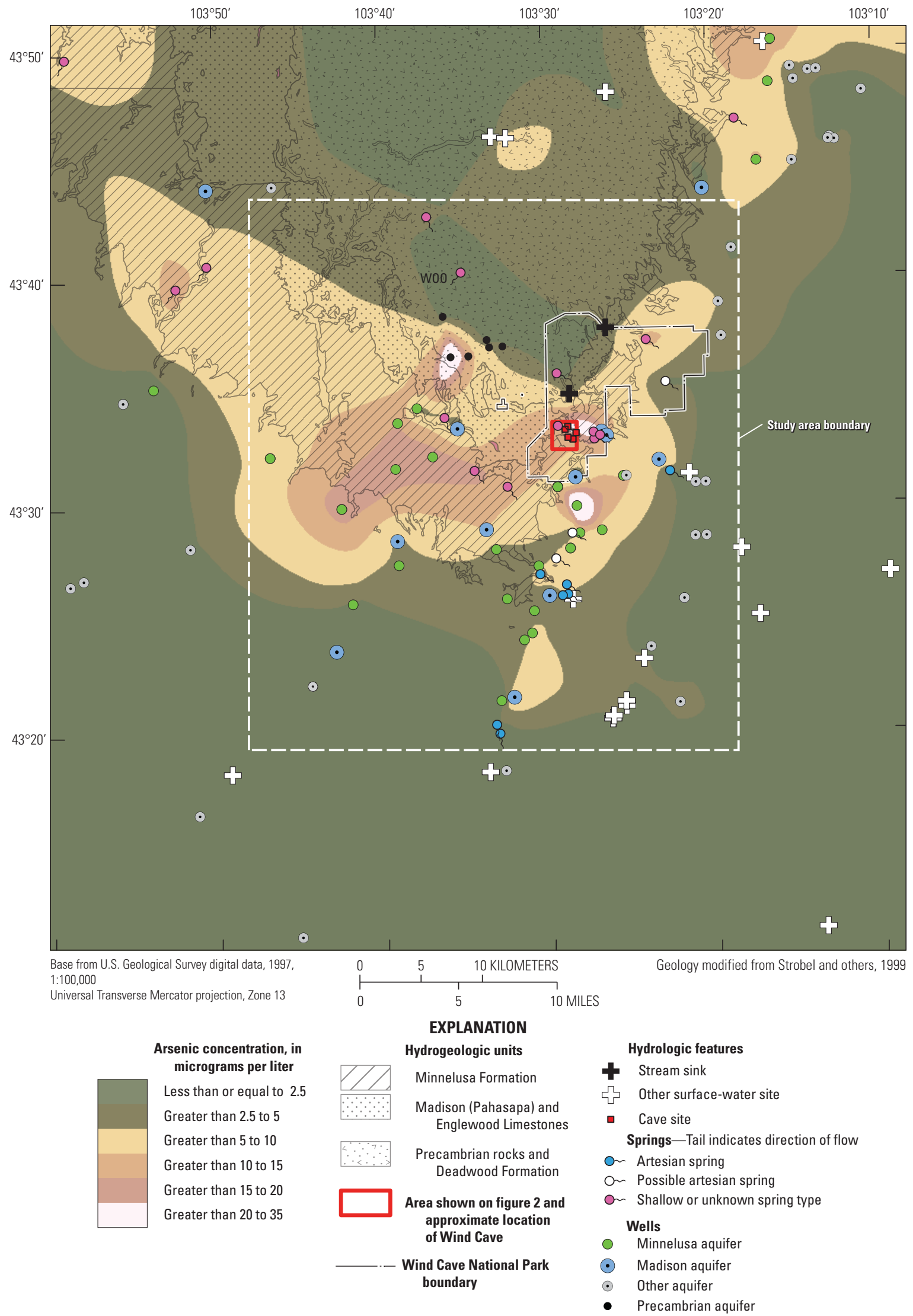

Figure 11. Geospatial distribution of arsenic concentrations for all groundwater and surface-water samples in and near the study area. (All relevant sites with arsenic data available from the National Water Information System [U.S. Geological Survey, 2011] are included in map.) 


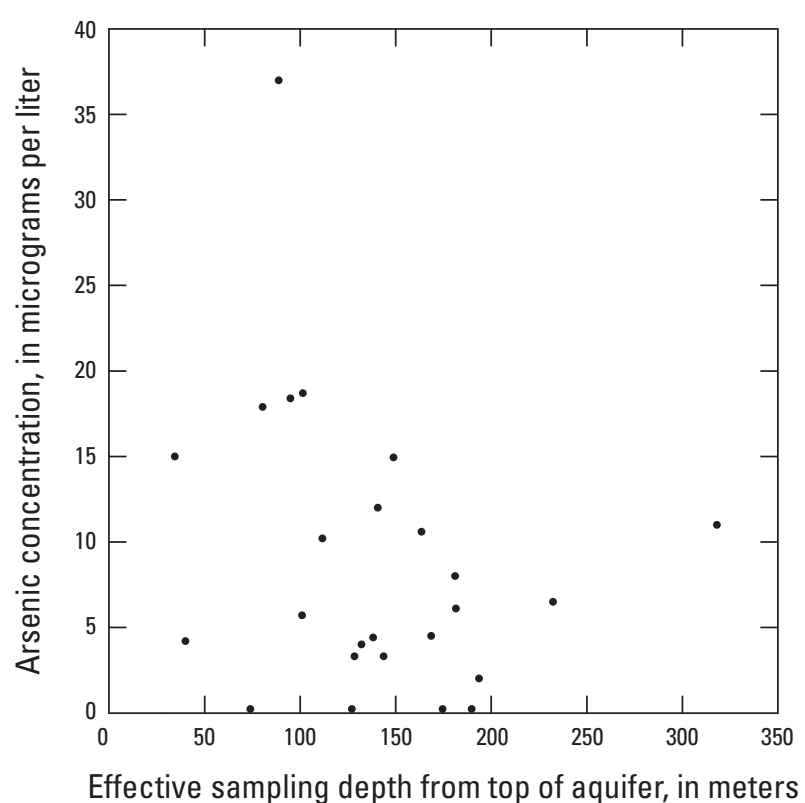

Figure 12. Scatter plot of arsenic concentrations in the Minnelusa aquifer and sampling depth from the top of the aquifer.

of which were negative, were multiplied by -1 for log transformation, then multiplied by -1 after transformation for consistency with the original sign. Values of $\mathrm{pH}$ were converted to hydrogen ion activity prior to normalization and standardization. To avoid giving disproportionate weight to any site, data for each site with multiple samples (excluding quality-control replicate samples) were averaged for PCA and end-member mixing so that each site had only one value per variable. Ten sites had missing data for one variable, and one site had missing data for four variables (1.2 percent of the dataset). However, because multiple samples were available for all of these sites, no values were missing in the site-averaged dataset. For end-member mixing, data were standardized to equalize variable weights and were not log transformed. The following results of PCA, cluster analysis, and end-member mixing are summarized from Long and Valder (2011).

\section{Principal Component and Cluster Analyses}

Results of PCA are shown as sampling sites plotted on the first two principal components, which explain 65 percent of the total variance of the data (fig. 14). Principal components 1,2 , and 3 represented 48, 17, and 11 percent, respectively, of the total variance, with higher order principal components representing fractions of the total variance that ranged from 0.03 to 7.9 percent. For cluster analysis, the number of clusters is specified by the user. Different numbers of clusters were tested with a maximum of six clusters. Five clusters were chosen because the five clusters that formed were separated by divisions that could be explained hydrogeologically and thus also would work well as a basis for an end-member mixing model (fig. 15). The PC cluster consists mainly of Precambrian aquifer sites. The West cluster consists of Minnelusa and Madison aquifer sites mainly located near or within the western surface recharge area of these aquifers. The East cluster is similar to the West cluster, except it includes all cave sites and the two stream sinks. The Artesian 1 cluster consists of all artesian springs near the Fall River and wells open to the Madison and Minnelusa aquifers in that general area, and the Artesian 2 cluster consists of the remaining artesian springs, which are all located within or near the outcrop of the Spearfish Formation. Because these cluster areas could be interpreted and differentiated hydrogeologically, these geospatial areas of the groundwater-flow system are referred to as "hydrogeologic domains." Hydrochemical data for these domains are summarized in table 13 .

The relative influences of principal components 1 and 2 on the five clusters are shown in figure 14. Principal component 1 separates the Artesian 1 and 2 clusters from the three clusters to the north and thus distinguishes groundwater affected by regional flow from that affected by local recharge. Hydrochemical differences between the Artesian 1 and 2 clusters account for the greatest variability in the dataset, which is indicated by the distances between clusters on figure 14 . The PC, East, and West clusters all are separated from each other on principal component 2, which therefore distinguishes groundwater affected by different local recharge sources. Also, differentiation of the East cluster from the PC and West clusters is associated with principal component 1 . The Artesian 1 and 2 clusters are separated on principal component 2 and account for the largest variability of this principal component (fig. 14). Therefore, in addition to distinguishing local recharge, principal component 2 describes differences between artesian springs.

Similarly to the way scores determine the plotting positions for sites (fig. 14), the term "loadings" refers to the plotting positions of the original variables (Davis, 2002). Sites and variables are plotted together and used to assess relations of variables and clusters (fig. 16). Because of the different ranges of the values of scores and loadings, these values were scaled to range from -1 to 1 so that sites and variables could be plotted together (fig. 16). The vector lengths of the variables indicate their respective relative influences, and all variables except arsenic, $\mathrm{pH}$, and bicarbonate have similar influence. Calcium, magnesium, sulfate, and specific conductance plot in the Artesian 2 cluster indicating a strong influence of these variables with this cluster, whereas the Artesian 1 cluster is influenced by sodium and chloride. Stable isotopes $\delta^{18} \mathrm{O}$ and $\delta^{2} \mathrm{H}$ plot near the East and West clusters and thus might help distinguish between these clusters, which is consistent with a gradient in these isotope values from east to west in the study area (Naus and others, 2001). The variables silica and magnesium are heavily loaded on principal component 2 and therefore are important in distinguishing clusters that are separated on that principal component. Most of the remaining variables mainly are loaded on principal component 1 and 


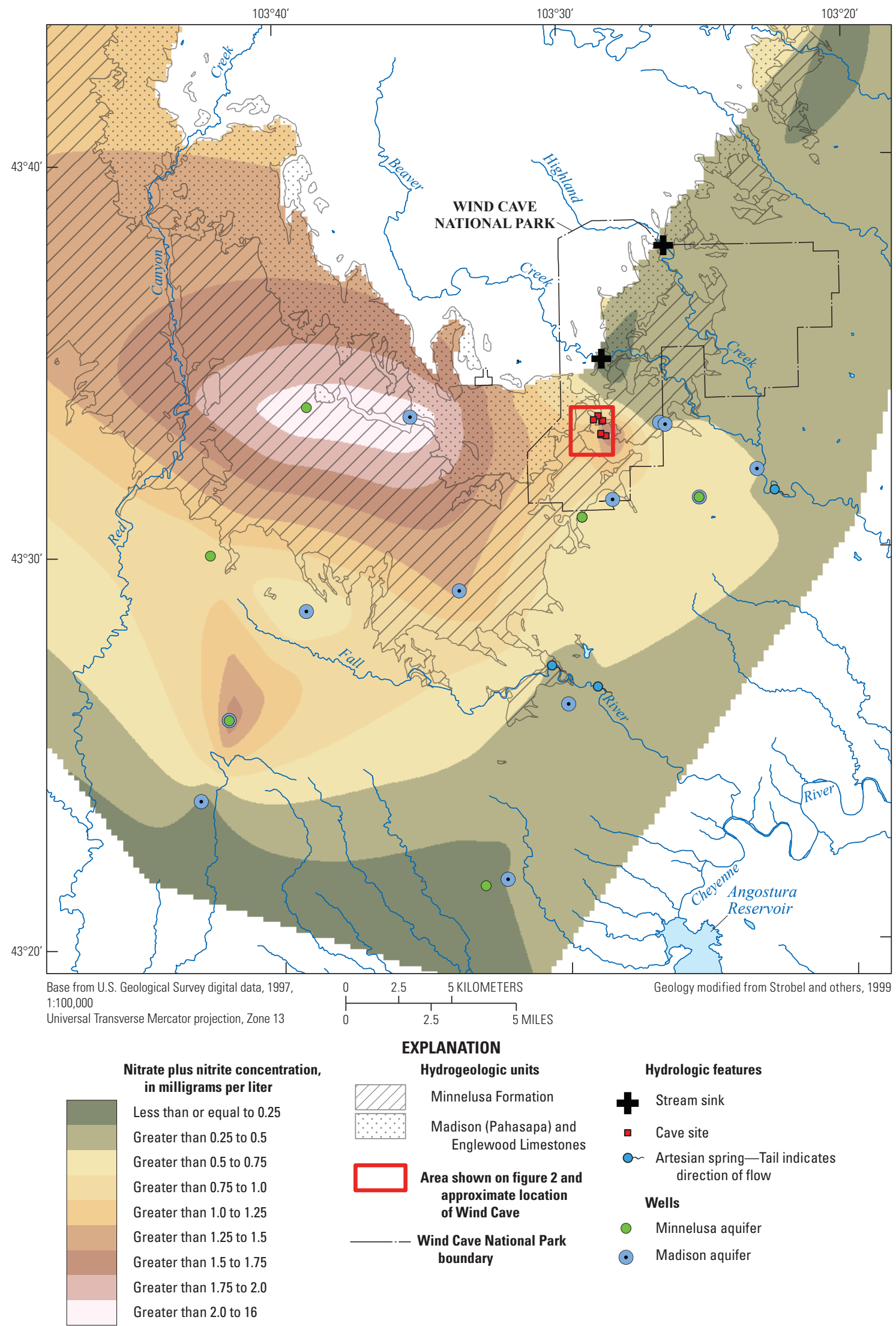

Figure 13. Geospatial distribution of nitrate plus nitrite for the Minnelusa and Madison aquifers in the study area. [All relevant sites with nitrate plus nitrite data available from the National Water Information System (U.S. Geological Survey, 2011) are included in the map]. 


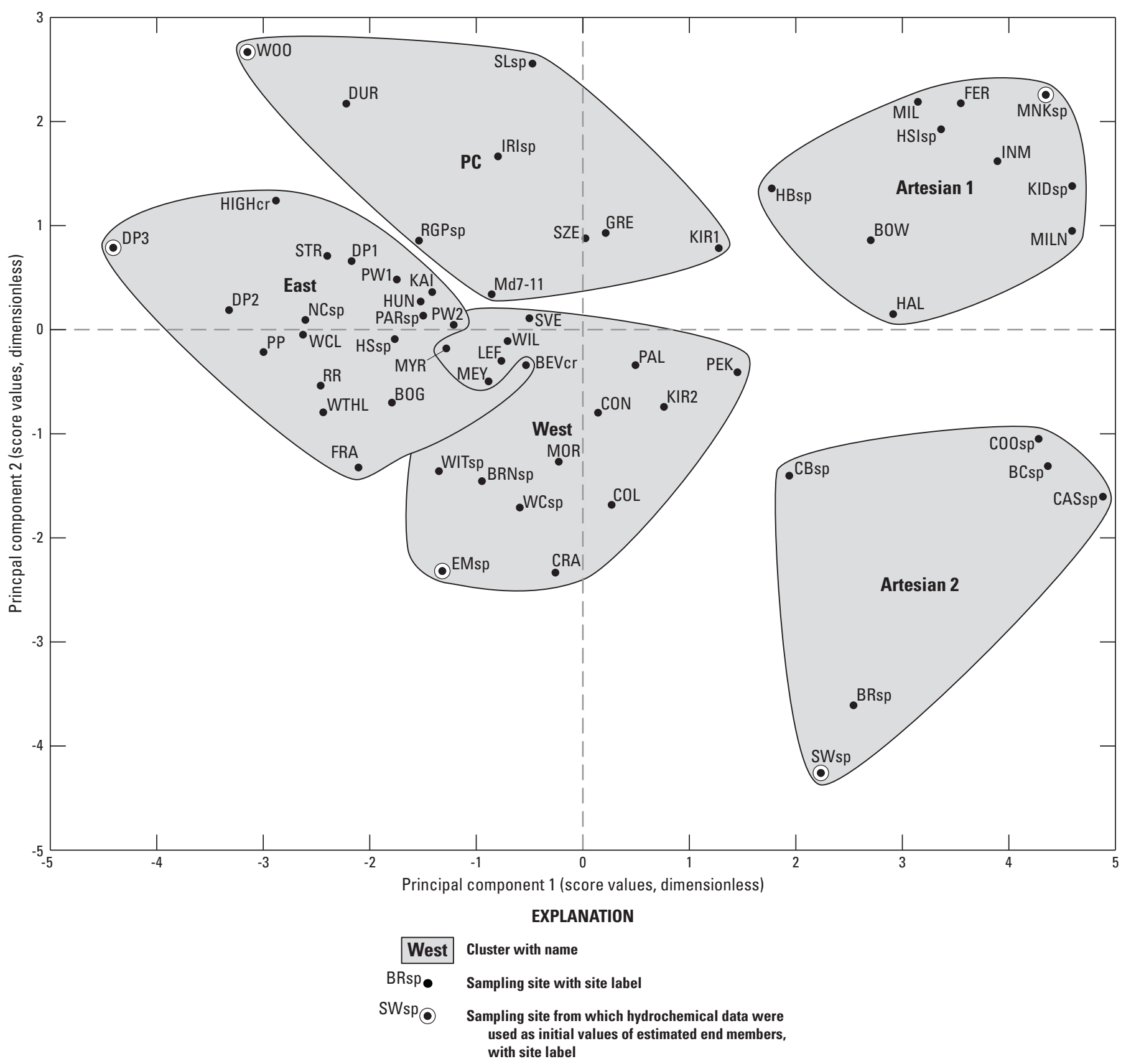

Figure 14. Results of principal component analysis (PCA) and cluster analysis for site-averaged data plotted on the first two principal component axes. The scores are the plotting positions for sites sampled.

thus primarily distinguish the Artesian 1 and 2 clusters from the three clusters to the north and secondarily distinguish clusters that are separated on principal component 2. Variables that plot proximally on figure 16 indicate correlation (Davis, 2002). For example, the conservative tracers $\delta^{18} \mathrm{O}$ and $\delta^{2} \mathrm{H}$ are correlated with each other and inversely correlated with sodium and chloride. The variables calcium, sulfate, and specific conductance also are correlated. 

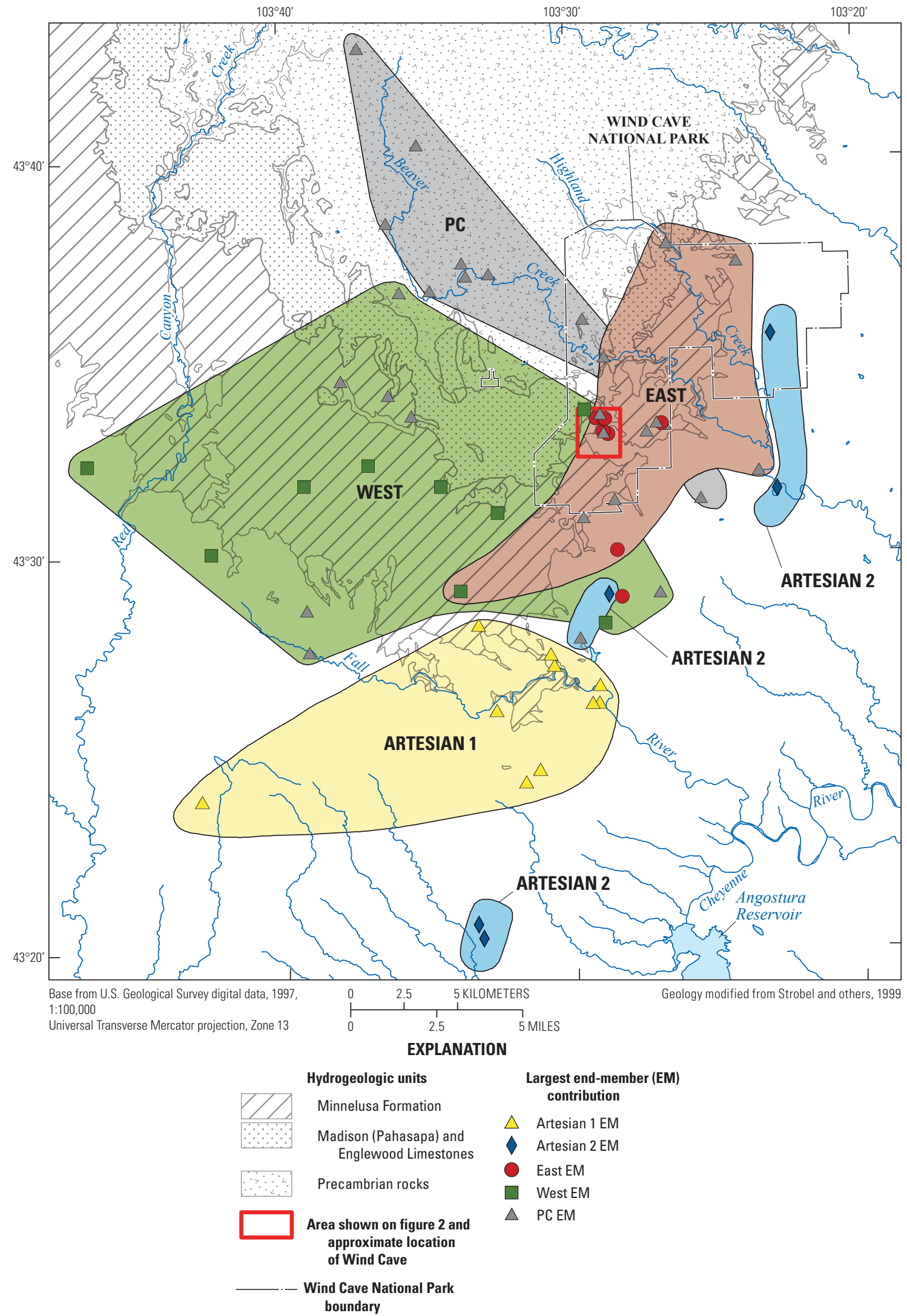

Largest end-member (EM) contribution

$\triangle$ Artesian $1 \mathrm{EM}$

$\checkmark$ Artesian $2 \mathrm{EM}$

East EM

$\square$ West EM

$\triangle \quad P C E M$

Figure 15. Results of cluster analysis showing the geographic locations of cluster areas. Results of endmember mixing are shown as the largest end-member contribution for each site in relation to the clusters. 


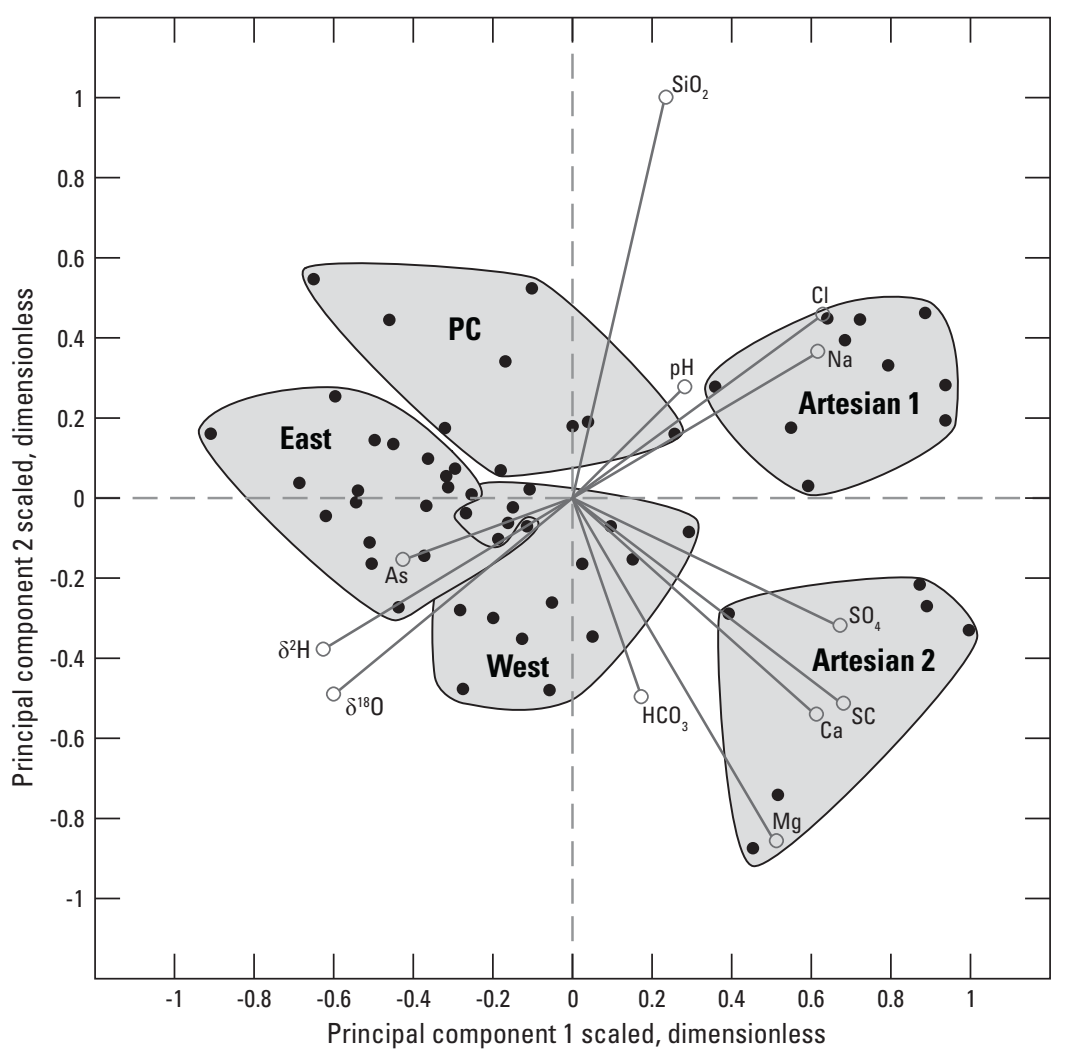

EXPLANATION

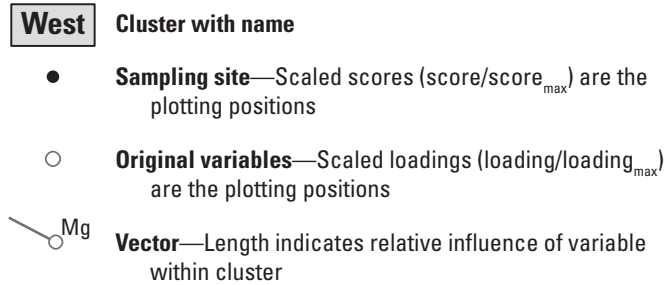

\section{End-Member Mixing}

For inverse modeling, initial values of $f_{i, k}$ and $E_{j, k}$ (equation 2) that are proximal to optimized values are desirable; otherwise these parameter values might be optimized to satisfy local minima of residuals, rather than the true minimum (Doherty, 2005). Initial values for estimated end-member concentrations $E_{j, k}$ were determined by PCA and cluster analysis by using the hydrochemistry of the site within each cluster that is farthest from the origin on figure 14. Such extreme-value points commonly are assumed to be end members (Christophersen and Hooper, 1992; Laaksoharju and others, 1999). During inverse modeling, end-member values were constrained to within 10 percent (plus or minus) of the total range of observation data for all sites.

As stated previously in the "Sample Collection and Hydrochemical Data" section, 12 variables were used in the PCA and end-member mixing: calcium, magnesium, sodium, bicarbonate, chloride, silica, sulfate, arsenic, $\delta^{18} \mathrm{O}, \delta^{2} \mathrm{H}$, specific conductance, and $\mathrm{pH}$. Model error in end-member mixing is introduced by neglecting geochemical evolution along flow paths from the interaction of rocks and water. If only the conservative tracers $\left(\delta^{18} \mathrm{O}, \delta^{2} \mathrm{H}\right.$, and chloride) are included in end-member mixing, then geochemical evolution need not be considered, but the model would be poorly constrained with only three variables for observation data. The model would be better constrained with 12 variables but would neglect geochemical evolution for 9 of the 12 variables. As a compromise, all 12 variables were used, but larger residuals were allowed for nonconservative variables than for conservative tracers. This was accomplished by preferentially weighting the calibration data (observed values) of conservative tracers by a factor of 2.0 for inverse modeling.

Water contributions from the Precambrian aquifer to the Madison and Minnelusa aquifers result from streams that drain Precambrian rocks, receive base flow from the Precambrian aquifer, and then sink into the Madison and Minnelusa aquifers. Precambrian aquifer contributions also might occur by direct groundwater underflow. However, flow in the opposite direction is not possible. Therefore, the end-member mixing model was constrained so that Precambrian aquifer sites could have contributions only from the PC end member, but that this end member could contribute to all sites. Mixing proportions for Precambrian aquifer sites were not estimated by inverse modeling but were set as fixed values, where the PC end-member proportion was set to 100 percent and other end-member contributions to zero. Also, it was assumed that the unsaturated part of the Minnelusa aquifer at this location could receive water only from proximal sources; that is, the East, West, or PC end members. Therefore, constraints were placed on mixing proportions for cave drip sites to satisfy this assumption.

Model constraints, such as this, based on hydrologic information are known as "prior information" in inverse modeling. This reduced the number of parameter values to optimize from 300 to 255 and resulted in a well constrained model 
with 2.8 times as many observed values (720) as parameter values to be optimized. This effectively forced the PC end member to have final estimated values that are approximately the average of observed values for Precambrian aquifer samples. Also, this forced all simulated Precambrian aquifer sites to have exactly the same values as this end member, which was not desirable but was considered the best of all options.

After inverse modeling, the coefficient of determination $\left(\mathrm{R}^{2}\right)$ from a linear regression model (Davis, 2002) of observed and calculated values was 0.94 for conservative tracers and 0.74 for the other nine variables. Differences, or residuals, from the regression lines are interpreted as resulting from four sources of errors: data errors, model errors, temporal variability, or processes other than pure mixing (that is, geochemical evolution along flow paths). Conservative tracers were assumed to be unaffected by geochemical evolution, and thus regression residuals for these tracers represent the former three sources of error only, whereas residuals for nonconservative variables represent all four sources of error. Therefore, the reduction in the $\mathrm{R}^{2}$ value for nonconservative variables (21 percent smaller than for conservative tracers) is a model estimate of the effect of geochemical evolution relative to that of mixing. Grouping the sites by the largest end-member contribution resulted in 65 percent similarity to the clusteranalysis groupings (fig. 15), which indicates that 35 percent of the sites received their largest contribution from end members outside of their corresponding clusters.

\section{End-Member Mixing Evaluation}

Each end member was assumed to represent a different hydrogeologic domain, and thus, PCA was used to determine how each estimated end member paired with each cluster (table 7). The proximity of end members to clusters in principal-component space was the criterion. For all hydrogeologic domains except East, the largest end-member

Table 7. Physical interpretation of end-member waters.

\begin{tabular}{|c|c|}
\hline End member & Description of end member \\
\hline $\mathrm{PC}$ & Precambrian aquifer. \\
\hline East & $\begin{array}{l}\text { Recharge to exposed areas of Madison and } \\
\text { Minnelusa aquifers on the eastern side of the } \\
\text { Black Hills. }\end{array}$ \\
\hline West & $\begin{array}{l}\text { Recharge to exposed areas of Madison and } \\
\text { Minnelusa aquifers on the western side of the } \\
\text { Black Hills. }\end{array}$ \\
\hline Artesian 1 & $\begin{array}{l}\text { Regional Madison aquifer groundwater primarily } \\
\text { contributing to the Artesian } 1 \text { domain. }\end{array}$ \\
\hline Artesian 2 & $\begin{array}{l}\text { Regional Madison aquifer groundwater primarily } \\
\text { contributing to the Artesian } 2 \text { domain. }\end{array}$ \\
\hline
\end{tabular}

contribution was from its own end member. The largest contribution to the East domain was from the PC end member, and the West domain received equal amounts from the West and PC end members (table 8). The East and West end members are interpreted to represent surface recharge to the Madison and Minnelusa aquifers (table 7), and thus end-member mixing estimated that the Precambrian aquifer contribution is larger than that from local surface recharge for the East domain and about equal for the West domain. The Artesian 1 and 2 end members combined (or regional groundwater flow) contributed 60 and 67 percent to the Artesian 1 and 2 domains, respectively (table 8).

The Artesian 1 and 2 end members are interpreted to represent regional groundwater flow, primarily from the Madison aquifer, because they primarily contribute to artesian springs that have relatively large discharge rates (tables 7 and 8). The Artesian 1 and 2 end members contributed from 1 to 7 percent to the East and West domains (table 8), which is consistent with the interpretation that artesian springs discharge regional groundwater flow that probably has little effect on the East and West domains. The West end member contributed about 1.5 times as much as the East end member to the Artesian 1 and 2 domains (table 8), which is consistent with general southward and eastward groundwater flow in the study area (fig. 1).

Mean end-member contributions for Wind Cave sites (table 9) are similar to those of the entire East domain (table 8), except that the largest contribution for the cave sites was from the East end member, or local surface recharge (38 percent), and the second largest was from the PC end member (34 percent). This analysis indicates that contamination to the Precambrian aquifer has potential to affect groundwater in Wind Cave. The West end member, or surface recharge from the west, contributed 26 percent. The Artesian 1 and 2 end-member contributions were 0 and 4 percent, respectively, to cave water bodies and 0 percent to cave drip sites

Table 8. End-member contributions as an average to each cluster area.

[Shaded areas indicate the largest end-member contribution to each domain. PC, Precambrian aquifer]

\begin{tabular}{lccccc}
\hline \multirow{2}{*}{$\begin{array}{c}\text { Hydro- } \\
\text { geologic } \\
\text { domain }\end{array}$} & \multicolumn{5}{c}{ End-member (EM) contributions, in percent } \\
\cline { 2 - 6 } & $\begin{array}{c}\text { PC } \\
\text { EM }\end{array}$ & $\begin{array}{c}\text { East } \\
\text { EM }\end{array}$ & $\begin{array}{c}\text { West } \\
\text { EM }\end{array}$ & $\begin{array}{c}\text { Artesian 1 } \\
\text { EM }\end{array}$ & $\begin{array}{c}\text { Artesian 2 } \\
\text { EM }\end{array}$ \\
\hline PC & 95 & 3 & 2 & 0 & 1 \\
East & 39 & 33 & 25 & 1 & 3 \\
West & 34 & 21 & 34 & 4 & 7 \\
Artesian 1 & 13 & 9 & 19 & 56 & 4 \\
Artesian 2 & 10 & 9 & 15 & 14 & 53 \\
\hline
\end{tabular}


Table 9. End-member contributions for Wind Cave sites.

[PC, Precambrian aquifer]

\begin{tabular}{llccccc}
\hline \multirow{2}{*}{ Site name } & \multicolumn{1}{c}{ Site type } & \multicolumn{5}{c}{ End-member (EM) contributions, in percent } \\
\cline { 3 - 7 } & & PC EM & East EM & West EM & Artesian 1 EM & Artesian 2 EM \\
\hline DP1 & Cave drip & 27 & 41 & 30 & 0 & 0 \\
DP2 & Cave drip & 32 & 44 & 23 & 0 & 0 \\
DP3 & Cave drip & 45 & 39 & 17 & 0 & 0 \\
Drip mean & & 35 & 41 & 24 & 0 & 0 \\
PP & Cave water body & 33 & 34 & 30 & 0 & 3 \\
RR & Cave water body & 34 & 33 & 28 & 0 & 5 \\
WCL & Cave water body & 32 & 35 & 29 & 1 & 5 \\
WTHL & Cave water body & 30 & 34 & 31 & 0 & 4 \\
Water-body mean & & 32 & 34 & 29 & 0 & 2 \\
\hline Overall mean & & 34 & 38 & 26 & 0 & 5 \\
\hline
\end{tabular}

because of model constraints (table 9). This small contribution from the Artesian 2 end member to cave water bodies is possible because it represents regional flow from the west, which might contribute a small amount to the cave depending on anisotropic permeability.

Artesian springs were separated into two clusters because of differences in hydrochemistry, but the hydrogeologic distinction between these two groups of springs is not obvious. Values of temperature, specific conductance, and calcium plus sulfate for artesian springs were distinctly different between the two hydrogeologic domains (table 10). The reason for the differences in temperature is uncertain but might result from a geothermal anomaly in deep rocks near the Artesian 1 springs that affected upwelling water discharging from these springs. Geographically, the Artesian 1 domain is distinct from the Artesian 2 domain because it contains all springs near the Fall River in a small area, which combined with hydrochemical and thermal data, provides a basis for assuming that different hydrogeologic processes are occurring in these two areas. The Artesian 1 and 2 clusters are separated on principal component 2 and account for the largest variability of this principal component (fig. 14).

Back (2011) estimated that Beaver Creek Spring (site BCsp) had a contribution of 55-58 percent regional flow by using geochemical modeling and assuming that the spring was a mixture of regional flow, represented by well MIL, and local recharge, represented by Wind Cave water bodies. The end-member mixing model in the current study described in this report resulted in an estimate of 74 percent regional flow as a combination of the two regional-flow end members (Artesian 1 and 2) and 26 percent local recharge as a combination of the other three end members. The estimates from these two methods did not differ greatly, especially considering differences in the two methods, both of which have strengths and limitations. The approach used by Back (2011) simulated geochemical evolution by physical processes along two flow paths originating from two end members that were assumed to be represented by the samples selected. In contrast, the approach described in this report allowed for as many as five end members, which were estimated and not assumed to have been sampled, but did not simulate geochemical evolution by physical processes.

The separation on figure 14 of the Artesian 1 and 2 clusters from the other three clusters indicates distinct hydrochemical differences; this does not, however, indicate hydraulic separation between the different hydrogeologic domains.

Although the primary sources of groundwater and the groundwater flow paths to the different hydrogeologic domains may differ, the hydraulic head within any of these domains could affect the hydraulic head in the other domains. Results of the end-member mixing model indicate that all hydrogeologic domains (excluding Precambrian aquifer sites) received water from all upgradient end members (table 8), which indicates that the five domains all are hydraulically connected to some extent. For example, the Artesian 2 domain received 34 percent of its contribution from a combination of the PC, East, and West end members (table 8). This is consistent with the conclusions of Back (2011), which indicate that Beaver Creek Spring (site BCsp) is a mixture of local recharge and regional groundwater flow. Beaver Creek Spring and well STR have a spatial separation of only $1.2 \mathrm{~km}$ (fig. 1) but are within different hydrogeologic domains (Artesian 2 and East, respectively) and are hydrochemically dissimilar, as indicated on figure 14 by their distant plotting positions. Despite these hydrochemical differences, some degree of hydraulic connection between these two sites probably exists because of similar contributing end members indicated by the end-member mixing model: Beaver Creek Spring received 24 percent of its contribution 
Table 10. Temperature, specific conductance, and calcium plus sulfate in water samples from artesian springs.

$\left[{ }^{\circ} \mathrm{C}\right.$, degrees Celsius; $\mu \mathrm{S} / \mathrm{cm}$, microsiemens per centimeter at $25^{\circ} \mathrm{C} ; \mathrm{mg} / \mathrm{L}$, milligrams per liter]

\begin{tabular}{|c|c|c|c|}
\hline Constituent & Mean & Minimum & Maximum \\
\hline \multicolumn{4}{|c|}{ Artesian 1 hydrogeologic domain ${ }^{a}$} \\
\hline Temperature, ${ }^{\circ} \mathrm{C}$ & 26 & 24 & 32 \\
\hline $\begin{array}{l}\text { Specific conductance, } \\
\mu \mathrm{S} / \mathrm{cm}\end{array}$ & 961 & 672 & 1,580 \\
\hline $\begin{array}{l}\text { Calcium plus sulfate, } \\
\mathrm{mg} / \mathrm{L}\end{array}$ & 254 & 131 & 660 \\
\hline \multicolumn{4}{|c|}{ Artesian 2 hydrogeologic domain ${ }^{b}$} \\
\hline Temperature, ${ }^{\circ} \mathrm{C}$ & 19 & 18 & 19 \\
\hline $\begin{array}{l}\text { Specific conductance, } \\
\mu \mathrm{S} / \mathrm{cm}\end{array}$ & 2,315 & 1,960 & 2,560 \\
\hline $\begin{array}{l}\text { Calcium plus sulfate, } \\
\mathrm{mg} / \mathrm{L}\end{array}$ & 1,738 & 1,302 & 2,108 \\
\hline
\end{tabular}

from the PC and West end members combined, and well STR received 74 percent from these same end members.

\section{Groundwater Age Dating}

Age dating was useful for additional evaluation of endmember mixing results. Sample concentrations of the dissolved gasses argon, carbon dioxide, methane, nitrogen, and oxygen (table 11) were used to estimate the temperature of recharge water to improve the estimates of CFC-based groundwater age (table 4) and to assess possible CFC degradation by applying methods described by Plummer and Busenberg (2000). Groundwater samples commonly contain a mixture of water of different ages. The apparent age is an estimate of age that is based on the assumption that the sample contains water of a single age. Because any single sample from the Madison aquifer generally contains a mixture of ages ranging from 1 to more than 60 years (Long and Putnam, 2006), the apparent age is not useful for describing groundwater flow to a single well or spring. However, the apparent age is useful because it is assumed to be proportional to the average age of a groundwater sample, and thus, the apparent age is useful for assessing the general geospatial distribution of groundwater age.

Apparent ages for the Madison aquifer in the study area indicate that groundwater closest to surface recharge areas has the youngest apparent ages, with increasing apparent ages in deeper parts of the Madison and Minnelusa aquifers to the south (fig. 17). The geospatial distribution of apparent ages is consistent with that of specific conductance (fig. 8), where specific conductance generally is proportional to apparent age. Specific conductance increases with residence time in carbonate aquifers because of the dissolution of aquifer rocks with time. Apparent ages generally are consistent with results of end-member mixing. Sites within the East and West hydrogeologic domains have the youngest apparent ages, and these domains were estimated to receive 90-100 percent of their contributions from local surface recharge or from the shallow Precambrian aquifer (table 8). Sites within the Artesian 1 and 2 hydrogeologic domains have the oldest apparent ages, and these domains were estimated to receive 60-67 percent of their water from end members representing regional flow (table 8). Apparent groundwater ages for Wind Cave are more than 20 years, which might be a result of partial groundwater inflow from the Precambrian aquifer and is consistent with results of the end-member mixing model.

Water from well MIL had the oldest apparent age of all samples, which indicates a regional source for this well and is consistent with end-member mixing results. Based on flow directions indicated by Back and others (1983), the regional source for this well probably is groundwater recharge in the northwestern part of the study area and also areas outside of the study area to the northwest. Also indicated by Back and others (1983), this regional flow sweeps around the southern end of the Black Hills and flows to the east, which would indicate that Cascade and Cool Springs (sites CASsp and COOsp) probably receive water from this regional source. The younger groundwater age for these springs relative to well MIL indicates that the springs also have contributions from water recharged at a nearer source, from faster flow paths, or both. A possible explanation for this difference in water sources might be karst conduits in the Madison aquifer that connect springs to local recharge areas. The Artesian 1 and 2 hydrogeologic domains each were estimated to receive 41 and 34 percent, respectively, of their water from the PC, East, and West clusters combined (table 8).

The apparent age for water from well Md7-11 was 61 years for CFC-12, which was much older than that of other proximal sites (table 4). An apparent age of 30 to 40 years might be expected for well Md7-11 based on apparent ages for proximal sites and its location near the Madison Limestone outcrop. This difference might be because this well is an observation well and not used for water production. Wells used for water production commonly are developed for maximum yield during installation. In a karst aquifer, this might result in the ability of the well to reach faster groundwater flow paths, such as conduits, than otherwise would be the case. Such well development is not necessary for an observation well that is used only to measure water levels. Therefore, water sampled from an observation well might represent water moving in a slower flow path with an older apparent age than for a production well. All wells other than Md7-11 were pumped regularly. Therefore, the apparent age for well Md7-11 was not plotted on figure 17 because it would result in a potentially misleading anomaly.

Methane was present in the samples from well Md7-11, which could cause degradation of CFCs resulting in a lowering of the concentration, particularly for $\mathrm{CFC}-11$ (Plummer 
Table 11. Dissolved gas data for water samples.

$\left[{ }^{\circ} \mathrm{C}\right.$, degrees Celsius; $\mathrm{mg} / \mathrm{L}$, milligrams per liter; $\mathrm{m}$, meters]

\begin{tabular}{|c|c|c|c|c|c|c|c|c|c|c|c|c|}
\hline $\begin{array}{c}\text { Site } \\
\text { name }\end{array}$ & Station number & Station name & Date & Time & $\begin{array}{c}\text { Sample } \\
\text { temperature } \\
\left({ }^{\circ} \mathrm{C}\right)\end{array}$ & $\begin{array}{l}\text { Argon } \\
(\mathrm{mg} / \mathrm{L})\end{array}$ & $\begin{array}{c}\text { Carbon } \\
\text { dioxide } \\
\text { (mg/L) }\end{array}$ & $\begin{array}{c}\text { Methane } \\
\text { (mg/L) }\end{array}$ & $\begin{array}{c}\text { Nitrogen } \\
\text { (mg/L) }\end{array}$ & $\begin{array}{c}\text { Oxygen } \\
\text { (mg/L) }\end{array}$ & $\begin{array}{l}\text { Approximate } \\
\text { recharge } \\
\text { elevation } \\
\text { (m) }\end{array}$ & $\begin{array}{c}\text { Temperature } \\
\text { of recharge } \\
\text { water }^{\mathrm{a}} \\
\left({ }^{\circ} \mathrm{C}\right)\end{array}$ \\
\hline CASsp & 432006103330501 & 8S 5E20CDAB & $06 / 19 / 2009$ & 1135 & 19.31 & 0.58 & 38.53 & 0.00 & 16.12 & 3.38 & 1,830 & 9.7 \\
\hline CASsp & 432006103330501 & $8 \mathrm{~S} 5 \mathrm{E} 20 \mathrm{CDAB}$ & 06/19/2009 & 1135 & 19.31 & .57 & 38.28 & .00 & 15.92 & 3.28 & 1,830 & 10.1 \\
\hline COOsp & 432028103331601 & 8S 5E20BDCB & $06 / 19 / 2009$ & 1438 & 17.78 & .56 & 31.78 & .00 & 15.28 & 4.51 & 1,830 & 9.8 \\
\hline COOsp & 432028103331601 & 8S 5E20BDCB & 06/19/2009 & 1438 & 17.78 & .56 & 31.71 & .00 & 15.20 & 4.60 & 1,830 & 10.1 \\
\hline KIDsp & 432605103285401 & 7S 5E14DDD & 06/19/2009 & 1645 & 27.77 & .47 & 30.47 & .00 & 12.31 & 3.90 & 1,830 & 16.3 \\
\hline KIDsp & 432605103285401 & 7S 5E14DDD & 06/19/2009 & 1645 & 27.77 & .47 & 29.85 & .00 & 11.99 & 3.81 & 1,830 & 16.2 \\
\hline MNKsp & 432605103290901 & 7S 5E14D & 05/28/2009 & 1510 & 32.43 & .56 & 27.92 & .00 & 15.15 & 3.55 & 1,830 & 10.8 \\
\hline MNKsp & 432605103290901 & 7S 5E14D & $05 / 28 / 2009$ & 1510 & 32.43 & .55 & 27.88 & .00 & 15.07 & 3.49 & 1,830 & 10.9 \\
\hline HSIsp & 432632103285302 & 7S 5E14DDDA & $05 / 21 / 2009$ & 1602 & 27.38 & .51 & 21.87 & .00 & 13.48 & 4.25 & 1,830 & 12.9 \\
\hline HSIsp & 432632103285302 & 7S 5E14DDDA & $05 / 21 / 2009$ & 1602 & 27.38 & .51 & 21.30 & .00 & 13.50 & 4.56 & 1,830 & 13.1 \\
\hline HBsp & 432703103302801 & 7S 5E10DCBA & $04 / 20 / 2007$ & 1726 & 23.90 & .55 & 18.14 & .00 & 14.25 & 6.32 & 1,830 & 9.7 \\
\hline HBsp & 432703103302801 & 7S 5E10DCBA & $04 / 20 / 2007$ & 1726 & 23.90 & .54 & 18.17 & .00 & 14.11 & 6.31 & 1,830 & 9.9 \\
\hline HBsp & 432703103302801 & 7S 5E10DCBA & $05 / 28 / 2009$ & 1339 & 23.62 & .57 & 18.60 & .00 & 15.48 & 5.71 & 1,830 & 9.2 \\
\hline HBsp & 432703103302801 & 7S 5E10DCBA & $05 / 28 / 2009$ & 1339 & 23.62 & .57 & 18.57 & .00 & 15.50 & 5.66 & 1,830 & 9.3 \\
\hline SVE & 432825103391201 & 7S 4E 4BACA & 09/02/2009 & 1040 & 18.12 & .59 & 17.69 & .00 & 16.03 & 7.39 & 1,830 & 8.1 \\
\hline SVE & 432825103391201 & 7S 4E 4BACA & 09/02/2009 & 1040 & 18.12 & .59 & 17.91 & .00 & 16.06 & 7.10 & 1,830 & 8.3 \\
\hline HUN & 433034103284701 & 6S 5E23DBBB & $04 / 17 / 2007$ & 940 & 14.98 & .62 & 10.20 & .00 & 17.27 & 7.04 & 1,830 & 7.3 \\
\hline HUN & 433034103284701 & $6 \mathrm{~S} 5 \mathrm{E} 23 \mathrm{DBBB}$ & $04 / 17 / 2007$ & 940 & 14.98 & .61 & 10.11 & .00 & 17.19 & 6.67 & 1,830 & 7.6 \\
\hline Md7-11 & 433115103251401 & 6S 6E21BBBB (CU91A) & $04 / 20 / 2007$ & 1350 & 13.40 & .61 & 9.05 & .01 & 17.10 & 1.93 & 1,830 & 8.4 \\
\hline $\operatorname{Md} 7-11$ & 433115103251401 & 6S 6E21BBBB (CU91A) & $04 / 20 / 2007$ & 1350 & 13.40 & .60 & 8.80 & .01 & 16.93 & 1.85 & 1,830 & 8.5 \\
\hline BCsp & 433128103223401 & 6S 6E14CDB & $04 / 17 / 2007$ & 1230 & 19.12 & .58 & 31.49 & .00 & 16.04 & 3.07 & 1,830 & 9.9 \\
\hline BCsp & 433128103223401 & 6S 6E14CDB & $04 / 17 / 2007$ & 1230 & 19.12 & .57 & 31.81 & .00 & 15.97 & 3.01 & 1,830 & 10.1 \\
\hline BCsp & 433128103223401 & 6S 6E14CDB & $05 / 28 / 2009$ & 1020 & 18.48 & .58 & 30.49 & .00 & 16.05 & 3.04 & 1,830 & 10.2 \\
\hline BCsp & 433128103223401 & $6 \mathrm{~S} 6 \mathrm{E} 14 \mathrm{CDB}$ & $05 / 28 / 2009$ & 1020 & 18.48 & .58 & 30.72 & .00 & 16.14 & 2.98 & 1,830 & 9.7 \\
\hline STR & 433150103230501 & 6S 6E15ABDD & $04 / 17 / 2007$ & 1430 & 20.02 & .61 & 6.91 & .00 & 16.99 & 7.16 & 1,830 & 8.0 \\
\hline STR & 433150103230501 & 6S 6E15ABDD & $04 / 17 / 2007$ & 1430 & 20.02 & .61 & 6.62 & .00 & 16.94 & 7.30 & 1,830 & 8.2 \\
\hline STR & 433150103230501 & 6S 6E15ABDD & $05 / 22 / 2009$ & 1117 & 19.24 & .61 & 8.50 & .00 & 17.32 & 5.18 & 1,830 & 8.0 \\
\hline STR & 433150103230501 & 6S 6E15ABDD & $05 / 22 / 2009$ & 1117 & 19.24 & .61 & 8.56 & .00 & 17.34 & 5.29 & 1,830 & 8.3 \\
\hline PW1 & 433311103263101 & 6S 6E 6DDAB & 07/29/2009 & 1325 & 14.66 & .61 & 9.14 & .00 & 17.23 & 6.13 & 1,520 & 9.7 \\
\hline PW1 & 433311103263101 & 6S 6E 6DDAB & 07/29/2009 & 1330 & 14.66 & .61 & 9.15 & .00 & 17.22 & 6.21 & 1,520 & 9.6 \\
\hline
\end{tabular}


Table 11. Dissolved gas data for water samples.-Continued

$\left[{ }^{\circ} \mathrm{C}\right.$, degrees Celsius; $\mathrm{mg} / \mathrm{L}$, milligrams per liter; $\mathrm{m}$, meters $]$

\begin{tabular}{|c|c|c|c|c|c|c|c|c|c|c|c|c|}
\hline $\begin{array}{c}\text { Site } \\
\text { name }\end{array}$ & Station number & Station name & Date & Time & $\begin{array}{c}\text { Sample } \\
\text { temperature } \\
\left({ }^{\circ} \mathrm{C}\right)\end{array}$ & $\begin{array}{l}\text { Argon } \\
(\mathrm{mg} / \mathrm{L})\end{array}$ & $\begin{array}{c}\text { Carbon } \\
\text { dioxide } \\
\text { (mg/L) }\end{array}$ & $\begin{array}{l}\text { Methane } \\
\text { (mg/L) }\end{array}$ & $\begin{array}{c}\text { Nitrogen } \\
\text { (mg/L) }\end{array}$ & $\begin{array}{c}\text { Oxygen } \\
\text { (mg/L) }\end{array}$ & $\begin{array}{l}\text { Approximate } \\
\text { recharge } \\
\text { elevation } \\
\text { (m) }\end{array}$ & $\begin{array}{c}\text { Temperature } \\
\text { of recharge } \\
\text { water }^{\mathrm{a}} \\
\left({ }^{\circ} \mathrm{C}\right)\end{array}$ \\
\hline PW2 & 433311103263102 & 6S 6E 6DDAA & $07 / 29 / 2009$ & 1010 & 14.49 & 0.82 & 7.46 & 0.00 & 28.29 & 3.85 & 1,520 & 7.4 \\
\hline PW2 & 433311103263102 & 6S 6E 6DDAA & $07 / 29 / 2009$ & 1015 & 14.49 & .82 & 7.45 & .00 & 28.30 & 3.89 & 1,520 & 7.0 \\
\hline $\mathrm{CON}$ & 433326103352001 & 6S 4E 1DBBB & 07/15/2009 & 942 & 12.49 & .63 & 41.14 & .00 & 18.09 & 4.44 & 1,400 & 9.2 \\
\hline $\mathrm{CON}$ & 433326103352001 & 6S 4E 1DBBB & $07 / 15 / 2009$ & 942 & 12.46 & .63 & 41.95 & .00 & 18.14 & 4.17 & 1,400 & 9.2 \\
\hline WOO & 433636103343901 & 5S 5E18CCAC & $04 / 26 / 2007$ & 1730 & 15.22 & .58 & 8.73 & .00 & 15.86 & 8.76 & 1,830 & 9.3 \\
\hline WOO & 433636103343901 & 5S 5E18CCAC & $04 / 26 / 2007$ & 1730 & 15.22 & .58 & 8.71 & .00 & 15.85 & 8.69 & 1,830 & 9.1 \\
\hline WOO & 433636103343901 & 5S 5E18CCAC & 07/15/2009 & 1422 & 15.90 & .59 & 11.79 & .00 & 16.26 & 9.06 & 1,830 & 9.0 \\
\hline WOO & 433636103343901 & 5S 5E18CCAC & $07 / 15 / 2009$ & 1422 & 15.90 & .59 & 11.68 & .00 & 16.12 & 9.14 & 1,830 & 9.0 \\
\hline
\end{tabular}

a Determined by methods described by Plummer and Busenberg (2000). 


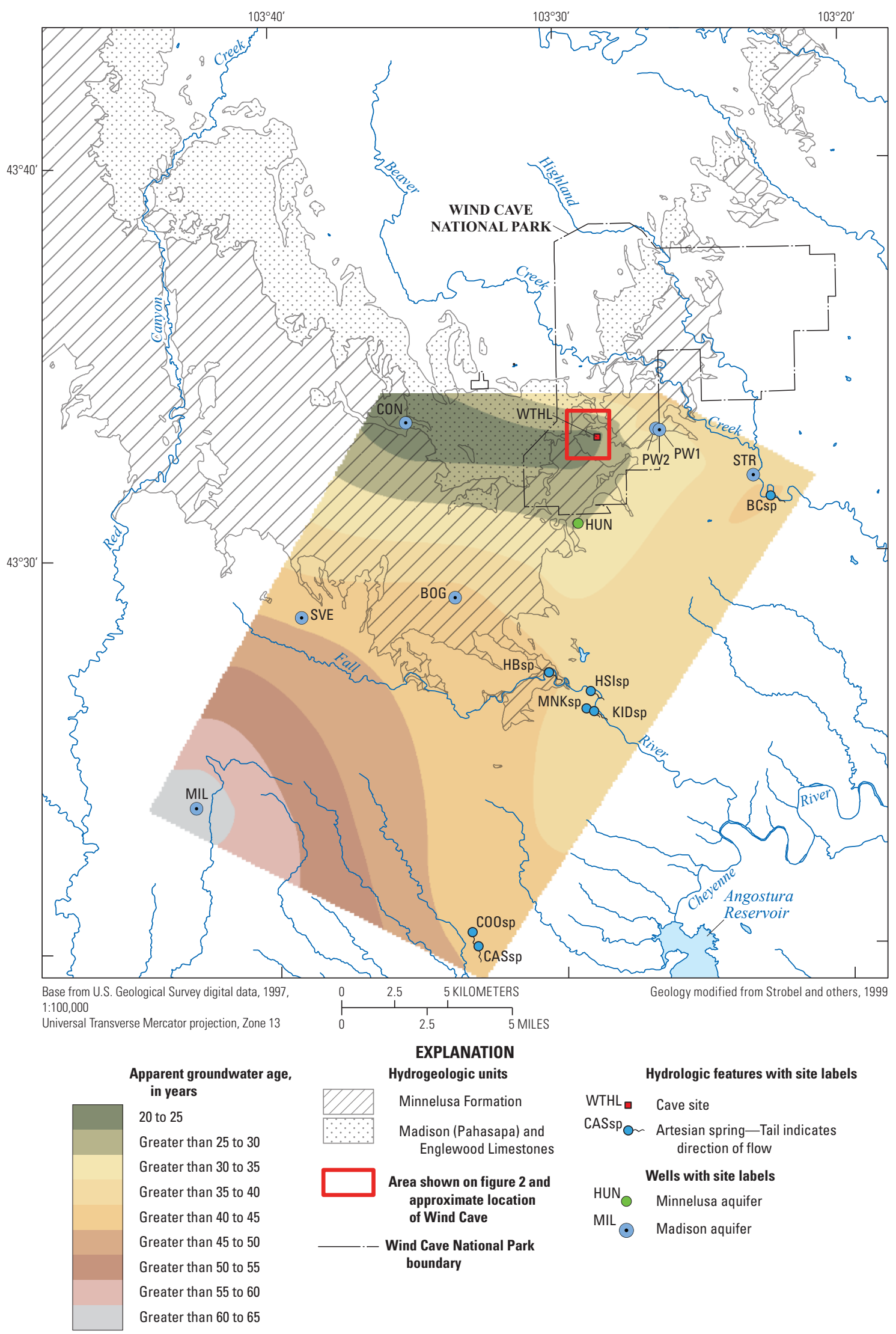

Figure 17. Geospatial distribution of apparent groundwater ages for the Madison aquifer estimated from CFC-12. 
and Busenberg, 2000). This would result in an apparent age that is older than for the case of no CFC degradation, and the apparent ages for Md7-11 are, therefore, considered to be the minimum apparent ages. Well Md7-11 is under hydraulic pressure at the land surface and sealed at the wellhead. To prevent freezing of the wellhead during winter, an antifreeze solution that is lighter than water is kept inside the top several feet of the well casing. Although the antifreeze solution was removed, and the well was allowed to flow overnight to clear the well before sampling, it is possible that the methane was a result of this antifreeze solution.

\section{Summary and Conclusions}

A study of groundwater flow, quality, and mixing in relation to Wind Cave National Park in western South Dakota was conducted during 2007-10 by the U.S. Geological Survey in cooperation with the National Park Service because of water-quality concerns and to determine possible sources of groundwater contamination in the Wind Cave National Park area. Wind Cave is a primary natural resource for the park, and groundwater in the cave exists as cave drip at numerous locations and in underground streams, pools, and lakes. A large area surrounding the park was included in this study because to understand groundwater in the park, a general understanding of groundwater hydrochemistry and flow in the surrounding area of the southern Black Hills is necessary. Three primary aquifers interact with groundwater in Wind Cave: the Minnelusa, Madison and Precambrian aquifers. The Minnelusa aquifer is contained in the Minnelusa Formation, which is composed of interbedded limestone, dolostone, sandstone, and shale. The Madison Limestone and underlying Englewood Limestone contain Wind Cave and the Madison aquifer, which is a karstic aquifer. The Precambrian aquifer is contained in the underlying metamorphic and igneous fractured rocks of Precambrian age.

Groundwater and surface-water samples collected for this study were analyzed for common ions (calcium, magnesium, sodium, bicarbonate, chloride, silica, and sulfate), arsenic, stable isotopes of oxygen and hydrogen, specific conductance, and $\mathrm{pH}$. These 12 variables were used in all multivariate methods. A total of 100 samples were collected from 60 sites from 2007 to 2010 and included stream sinks, cave drip, cave water bodies, springs, and wells. Groundwater samples were collected and analyzed for chlorofluorocarbons (CFCs), dissolved gasses (argon, carbon dioxide, methane, nitrogen, and oxygen), and tritium at selected sites and used to estimate groundwater age.

Multivariate methods were applied to hydrochemical data to characterize groundwater flow and mixing for these three aquifers. The first of these methods is principal component analysis (PCA), which is used to graphically plot complex multivariate datasets and elucidate data patterns that otherwise might not be noticed. The second method is cluster analysis, which consists of the assignment of data points to a specified number of groups, or clusters, based on similarity of data. Finally, an end-member mixing model was used to estimate groundwater mixing and flow. This model is based on the assumption that each water sample consists of water originating from one or more end members, or sources of input, in varying proportions. Application of these methods provided a basis to assess characteristics important for groundwater quality, including the differentiation of hydrogeologic domains within the study area, sources of groundwater to these domains, and groundwater mixing within these domains.

In general, groundwater flows from the surface recharge area in the northwestern part of study area to the southwest, then sweeps east and then northeast around the southern end of the Black Hills. A low area in the potentiometric surface in the area of Wind Cave likely indicates anomalously high permeability resulting from extensive karst development. Vertical hydraulic gradients between the Madison and Minnelusa aquifers indicates that the primary source of artesian spring flow is the Madison aquifer. Dye tracing indicated hydraulic connectivity of three water bodies in Wind Cave. Fluorescent dye injected into What the Hell Lake reached Rebel River and Windy City Lake with minimum velocities of 9 meters per day.

Specific conductance generally is lowest in recharge areas for the Minnelusa, Madison, and Precambrian aquifers and highest in the southern part of the study area, distant from aquifer recharge areas. Arsenic concentrations in samples collected for this study ranged from 0.28 to 37.1 micrograms per liter $(\mathrm{mg} / \mathrm{L})$ with a median value of $6.4 \mathrm{mg} / \mathrm{L}$, and 32 percent of these concentrations exceeded $10 \mathrm{mg} / \mathrm{L}$, which is the Maximum Contaminant Level (MCL) established by the U.S. Environmental Protection Agency. The highest arsenic concentrations in and near the study area are approximately coincident with the outcrop of the Minnelusa Formation and likely originated from arsenic in shale layers in the Minnelusa aquifer. Sample concentrations of nitrate plus nitrite were less than 2 milligrams per liter for 92 percent of samples collected, which is not a concern for drinking-water quality. Water samples were collected in the park and analyzed for five trace metals (chromium, copper, lithium, vanadium, and zinc), the concentrations of which did not correlate with arsenic concentrations. Sample concentrations for chromium and copper were less than 1 percent of their respective MCLs established by the U.S. Environmental Protection Agency.

For end-member mixing, end members were not assumed to have been sampled but rather were estimated and constrained by prior hydrologic knowledge in the end-member mixing model. This model was quantified in relation to the five hydrogeologic domains that were determined by PCA and cluster analysis, which focused model results on major hydrologic processes. Conservative tracers (chloride and stable isotopes of hydrogen and oxygen) were weighted preferentially in model calibration, which distributed model errors of optimized values, or residuals, more appropriately than would otherwise be the case. The smallest residuals were for conservative 
tracers, which is appropriate because geochemical evolution along groundwater flow paths for nonconservative variables was assumed to result in larger model residuals. The difference in residuals between conservative and nonconservative variables provided an estimate of the effect of geochemical evolution along flow paths relative to that of mixing, which was 21 percent.

Five hydrogeologic domains were distinguishable as a result of PCA, cluster analysis, and prior hydrogeologic knowledge. These are described as (1) the PC domain consisting mainly of Precambrian aquifer sites; (2) the West domain consisting of Madison and Minnelusa aquifer sites mainly located near or within the western surface recharge area of these aquifers; (3) the East domain, which is similar to the West domain, except it includes all cave sites and the two stream sinks; (4) the Artesian 1 domain consisting of all artesian springs near the Fall River and wells open to the Madison and Minnelusa aquifers in that general area; and (5) the Artesian 2 domain consisting of the remaining artesian springs, all of which are located within or near the outcrop of the Spearfish Formation. Each of the five end members estimated by the model were determined by PCA to be hydrochemically similar to one of the five domains. Thus, each domain included one estimated end member, and the end members were interpreted accordingly. The PC end member was interpreted to represent groundwater in the Precambrian aquifer; the East and West end members were interpreted to represent surface recharge in these domains; and the Artesian 1 and 2 end members were interpreted to represent regional groundwater flow contributing primarily to these domains. The end-member mixing model estimated that Wind Cave sites received 38 percent of their groundwater inflow from local surface recharge (East end member), 34 percent from the upgradient Precambrian aquifer, 26 percent originating from surface recharge to the west (West end member), and 2 percent from regional flow. The Artesian 1 and 2 end members combined contributed 60 and 67 percent to the Artesian 1 and 2 domains, respectively. This analysis indicates that contamination to the Precambrian aquifer has potential to affect groundwater in Wind Cave. Flow from the Precambrian aquifer into Wind Cave might occur from sinking streams that drain Precambrian rocks and also from direct groundwater transfer from the Precambrian aquifer, through the Deadwood aquifer, and into the Madison aquifer.

Apparent ages, or model ages, for the Madison aquifer in the study area indicate that groundwater closest to surface recharge areas is youngest, with increasing age in a downgradient direction toward deeper parts of the aquifer. Apparent groundwater ages for Wind Cave are more than 20 years, which might be a result of partial groundwater inflow from the Precambrian aquifer and is consistent with results of the endmember mixing model.

\section{References Cited}

Alexander, E.C., Davis, M.A., and Alexander, S.C., 1989, Hydrologic study of Jewel Cave and Wind Cave-Final report: University of Minnesota Report 0645-5647, Contract CX-1200-S-A047, $196 \mathrm{p}$.

Back, Jennifer, 2011, Geochemical investigation of the Madison aquifer, Wind Cave National Park, South Dakota: Natural Resource Technical Report NPS/NRPC/WRD/ NRTR—2011/416, 50 p.

Back, William, Hanshaw, B.B., Plummer, L.N., Rahn, P.H., Rightmire, C.T., and Rubin, M., 1983, Process and rate of dedolomitization-Mass transfer and ${ }^{14} \mathrm{C}$ dating in a regional carbonate aquifer: Geological Society of America Bulletin, v. 94, no. 12, p. 1,415-1,429.

Bakalowicz, M.J., Ford, D.C., Miller, T.E., Palmer, A.N., and Palmer, M.V., 1987, Thermal genesis of dissolution caves in the Black Hills, South Dakota: Geological Society of America Bulletin, v. 99, no. 6, p. 729-738.

Bingham, F.T., Bradford, G.R., and Page, A.L., 1964, Toxicity of lithium to plants: California Agriculture, September issue.

Brobst, D.A., and Epstein, J.B., 1963, Geology of the Fanny Peak quadrangle, Wyoming-South Dakota: U.S. Geological Survey Bulletin 1063-1, 377 p.

Cattermole, J.M., 1969, Geologic map of the Rapid City West quadrangle, Pennington County, South Dakota: U.S. Geological Survey Geologic Quadrangle GQ-0828, 1 sheet.

Childress, C.J.O., Foreman, W.T., Connor, B.F., and Maloney, T.J., 1999, New reporting procedures based on longterm method detection levels and some considerations for interpretations of water-quality data provided by the U.S. Geological Survey National Water Quality Laboratory: U.S. Geological Survey Open-File Report 99-193, 19 p.

Christophersen, N., and Hooper, R.P., 1992, Multivariate analysis of stream water chemical data; the use of principal components analysis for the end-member mixing problem: Water Resources Research, v. 28, no. 1, p. 99-107.

Cook, P.G., Solomon, D., Sanford, W.E., Busenberg, E., Plummer, L.N., and Poreda, R., 1996, Inferring shallow groundwater flow in saprolite and fractured rock using environmental tracers: Water Resources Research, v. 32, no. 6, p. 1,501-1,509.

Davis, J.C., 2002, Statistics and data analysis in geology (3d ed.): Hoboken, New Jersey, John Wiley and Sons, Inc., $638 \mathrm{p}$. 
Doherty, John, 2005, Pest-Model-Independent Parameter Estimation, user manual (5th ed.): Watermark Numerical Computing [variously paged].

Downey, J.S., 1986, Geohydrology of bedrock aquifers in the northern Great Plains in parts of Montana, North Dakota, South Dakota, and Wyoming: U.S. Geological Survey Professional Paper 1402-E, p. E1-E87.

Driscoll, D.G., Carter, J.M., Williamson, J.E., and Putnam, L.D., 2002, Hydrology of the Black Hills area, South Dakota: U.S. Geological Survey Water-Resources Investigations Report 02-4094, $150 \mathrm{p}$.

Eaton, A.D., Clesceri, L.S., and Greenberg, A.E., 1995, Standard methods for the examination of water and wastewater (19th ed.): Washington, D.C., American Public Health Association, American Water Works Association, Water Environment Federation [variously paged].

Even, H., Carmi, I., Magaritz, M., and Gerson, R., 1986, Timing the transport of water through the upper vadose zone in a karstic system above a cave in Israel: Earth Surface Processes and Landforms, v. 11, no. 2, p. 181-191.

Fishman, M.J., 1993, Methods of analysis by the U.S. Geological Survey National Water Quality Laboratory-Determination of inorganic and organic constituents in water and fluvial sediments: U.S. Geological Survey Open-File Report 93-125, 217 p.

Fishman, M.J., and Friedman, L.C., 1989, Methods for determination of inorganic substances in water and fluvial sediments: U.S. Geological Survey Techniques of WaterResources Investigations, book 5, chap. A1, 545 p.

Ford, D.C., Lundberg, J., Palmer, A.N., Palmer, M.V., Dreybrodt, W., and Schwarcz, H.P., 1993, Uranium-series dating of the draining of an aquifer-The example of Wind Cave, Black Hills, South Dakota: Geological Society of America Bulletin, v. 105, no. 2, p. 241-250.

Freeze, R.A., and Cherry, J.A., 1979, Groundwater: Englewood Cliffs, N.J., Prentice-Hall, 604 p.

Fritz, P., Cherry, J.A., Weyer, K.U., and Sklash, M., 1976, Storm runoff analyses using environmental isotopes and major ions, in Interpretation of environmental isotope and hydrochemical data in groundwater hydrology: Vienna, International Atomic Energy Agency (IAEA), p. 111-130, accessed November 15, 2010, at http://www-naweb.iaea. org/napc/ih/documents/IAEA\%20Monographs/STI\%20 429\%20Interpretation\%20nvironmental\%20isotope\%20 and\%20hydrochemical\%20data\%201976.PDF.
Garbarino, J.R., Kanagy, L.K., and Cree, M.E., 2006, Determination of elements in natural-water, biota, sediment and soil samples using collision/reaction cell inductively coupled plasma-mass spectrometry: U.S. Geological Survey Techniques and Methods, book 5, section B, chapter 1, 88 p.

Greene, E.A., 1993, Hydraulic properties of the Madison aquifer system in the western Rapid City area, South Dakota: U.S. Geological Survey Water-Resources Investigations Report 93-4008, 56 p.

Greene, E.A., and Rahn, P.H., 1995, Localized anisotropic transmissivity in a karst aquifer: Ground Water, v. 33, no. 5 , p. $806-816$.

Gries, J.P., and Martin, J.E., 1981, Composite outcrop section of the Paleozoic and Mesozoic strata in the Black Hills and surrounding areas, in Rich, F.J., ed., Geology of the Black Hills, South Dakota and Wyoming ( $2 \mathrm{~d}$ ed.): Field Trip Guidebooks, Geological Society of America Rocky Mountain Section 1981 Annual Meeting: Rapid City, S. Dak., American Geological Institute, p. 261-292.

Gries, J.P., 1996, Roadside geology of South Dakota: Missoula, Mont., Mountain Press Publishing Company, 358 p.

Gulden, B., 2011, NSS Geo2 Committee on Long and Deep Caves, accessed March 8, 2011, at http://www.caverbob. $\mathrm{com} /$.

Hayes, T.S., 1999, Episodic sediment-discharge events in Cascade Springs, southern Black Hills, South Dakota: U.S. Geological Survey Water-Resources Investigations Report 99-4168, 34 p.

Hayhurst, Barry, 2002, Site reassessment analytical results report-Pringle Post and Pole, Pringle, Custer County, South Dakota: CERCLIS ID No. SDD007261365, 335 p.

Heakin, A.J., 2004, Streamflow and water-quality characteristics for Wind Cave National Park, South Dakota, 2002-2003: U.S. Geological Survey Scientific Investigations Report 2004-5071, 68 p.

Hem, J.D., 1985, Study and interpretation of the chemical characteristics of natural water: U.S. Geological Survey Water-Supply Paper 2254, $263 \mathrm{p}$.

Horrocks, R.D., 2009, Developing a cave potential map of Wind Cave, in Palmer, A.N., and Palmer, M.V., eds., Caves and karst of the USA: Huntsville, Alabama, National Speleological Society, p. 218-220.

International Atomic Energy Agency, 2006, Use of chlorofluorocarbons in hydrology - A guidebook: Vienna, International Atomic Energy Agency, 277 p. 
Katz, B.G., 2004, Sources of nitrate contamination and age of water in large karstic springs of Florida: Environmental Geology, v. 46, p. 689-706.

Laaksoharju, M., Skårman, C., and Skårman, E., 1999, Multivariate mixing and mass balance (M3) calculations, a new tool for decoding hydrogeochemical information: Applied Geochemistry, v. 14 , no. 7 , p. 861-871.

Levenberg, Kenneth, 1944, A method for the solution of certain non-linear problems in least squares: Quarterly of Applied Mathematics, v. 2, p. 164-168.

Long, A.J., and Putnam, L.D., 2006, Translating CFC-based piston ages into probability density functions of groundwater age in karst: Journal of Hydrology, v. 330, no. 3-4, p. 735-747.

Long, A.J., Sawyer, J.F., and Putnam, L.D., 2008, Environmental tracers as indicators of karst conduits in ground water in South Dakota, USA: Hydrogeology Journal, v. 16, no. 2, p. 263-280.

Long, A.J., 2009, Hydrograph separation for karst watersheds using a two-domain rainfall-discharge model: Journal of Hydrology, v. 364, no. 3-4, p. 249-256.

Long, A.J., and Valder, J.F., 2011, Multivariate analyses with end-member mixing to characterize groundwater flow: Wind Cave and associated aquifers: Journal of Hydrology, v. 409, no. 1-2, p. 315-327, doi:10.1016/j.jhydrol.2011.08.028.

Marquardt, D.W., 1963, An algorithm for least-squares estimation of nonlinear parameters: Journal of the Society for Industrial and Applied Mathematics, v. 11, no. 2, p. 431-441.

Meyer, M.R., 1987, A summary of groundwater pollution problems in South Dakota: South Dakota Department of Water and Natural Resources, 18 p.

Muloin, Tracy, and Dudas, M.J., 2005, Aqueous phase arsenic in weathered shale enriched in native arsenic: Journal of Environmental Engineering and Science, v. 4, no. 6, p. 461-468.

Naus, C.A., Driscoll, D.G., and Carter, J.M., 2001, Geochemistry of the Madison and Minnelusa aquifers in the Black Hills area, South Dakota: U.S. Geological Survey WaterResources Investigations Report 01-4129, 118 p.

Oster, Harald, Sonntag, C., and Munnich, K.O., 1996, Groundwater age dating with chlorofluorocarbons: Water Resources Research, v. 32, no. 10, p. 2,989-3,001.

Palmer, A.N., and Palmer, M.V., 1989, Geological history of the Black Hills Caves, South Dakota: National Speleological Society Bulletin, no. 51, p. 72-99.
Peters, S.C., and Burkert, L., 2008, The occurrence and geochemistry of arsenic in groundwaters of the Newark Basin of Pennsylvania: Applied Geochemistry, v. 23, no. 1, p. 85-98.

Plummer, L.N., and Busenberg, E., 2000, Chlorofluorocarbons, in Cook, P.G., and Herczeg, A.L., eds., Environmental tracers in subsurface Hydrology: Norwell, Massachusetts, Kluwer Academic Press, p. 441-478.

Putnam, L.D., and Long, A.J., 2007, Characterization of ground-water flow and water quality for the Madison and Minnelusa aquifers in Northern Lawrence County, South Dakota: U.S. Geological Survey Scientific Investigations Report 2007-5001, 61 p.

Rahn, P.H., 2006, Nitrate in Rapid City's water supply: Proceedings of the South Dakota Academy of Science, v. 85, p. $31-42$.

Rahn, P.H., and Gries, J.P., 1973, Large springs in the Black Hills, South Dakota and Wyoming: South Dakota Geological Survey, Report of Investigations 107, 100 p.

Redden, J.A., and DeWitt, Ed, 2008, Maps showing geology, structure, and geophysics of the central Black Hills, South Dakota: U.S. Geological Survey Scientific Investigations Map 2777, 44 p. pamphlet, 2 sheets.

Révész, K., and Coplen, T.B., 2008a, Determination of the $\delta\left({ }^{18} 0 /{ }^{16} 0\right)$ of water-RSIL lab code 489 , in Révész, K., and Coplen, T.B., eds., Methods of the Reston Stable Isotope Laboratory: U.S. Geological Survey Techniques and Methods, book 10, chap. C2, p. 28.

Révész, K., and Coplen, T.B., 2008b, Determination of the $\delta\left({ }^{2} \mathrm{H} /{ }^{1} \mathrm{H}\right)$ of water: RSIL lab code 1574 , in Révész, K., and Coplen, T.B., eds., Methods of the Reston Stable Isotope Laboratory: U.S. Geological Survey Techniques and Methods, book 10, chap. C1, p. 27.

Rhine, E.D., Onesios, K.M., Serfes, M.E., Reinfelder, J.R., and Young, L.Y., 2008, Arsenic transformation and mobilization from minerals by the arsenite oxidizing strain WAO: Environmental Science and Technology, v. 42, no. 5, p. 1,423-1,429.

Seber, G.A.F., 1984, Multivariate observations: Hoboken, New Jersey, John Wiley and Sons, Inc., 686 p.

Serfes, M.E., Spayd, S.E., and Herman, G.C., 2006, Arsenic occurrence, sources, mobilization, and transport in groundwater in the Newark Basin of New Jersey: ACS Symposium Series, v. 915, p. 175-190.

Shouse, Ben, 2004, Drought expands Wind Cave entry: Sioux Falls, South Dakota, Argus Leader, September 13, 2004. 
Spath, Helmuth, 1985, Cluster dissection and analysisTheory, FORTRAN programs, examples: New York, Halsted Press, 226 p.

Strobel, M.L., Jarrell, G.J., Sawyer, J.F., Schleicher, J.R., and Fahrenbach, M.D., 1999, Distribution of hydrogeologic units in the Black Hills Area, South Dakota: U.S. Geological Survey Hydrologic Investigations Atlas HA-0743, 3 sheets.

Suk, H., and Lee, K., 1999, Characterization of a ground water hydrochemical system through multivariate analysis - Clustering into ground water zones: Ground Water, v. 37, no. 3, p. 358-366.

Taylor, J.R., 2003, Evaluating groundwater nitrates from on-lot septic systems, a guidance model for land planning in Pennsylvania: Malvern, Pennsylvania, Penn State Great Valley School of Graduate Professional Studies, 12 p., accessed August 15, 2011, at http://www.taylorgeoservices. com/papers/nitratereport.PDF.

Thatcher, L.L., Janzer, V.J., and Edwards, K.W., 1977, Methods for determination of radioactive substances in water and fluvial sediments: U.S. Geological Survey Techniques of Water-Resources Investigations, book 5, chap. A5, p. 79-81.

Tuttle, M.L.W., Breit, G.N., and Goldhaber, M.B., 2009, Weathering of the New Albany Shale, Kentucky-II. Redistribution of minor and trace elements: Applied Geochemistry, v. 24, no. 8, p. 1,565-1,578.
U.S. Environmental Protection Agency, 2010, Drinking water contaminants, accessed February 8, 2011, at http://water. epa.gov/drink/contaminants/.

U.S. Geological Survey, 2011, National Water Information System (NWISWeb): U.S. Geological Survey database, accessed August 15, 2011, at http://waterdata.usgs.gov/sd/ nwis/.

U.S. Geological Survey, variously dated, National field manual for the collection of water-quality data: U.S. Geological Survey Techniques of Water-Resources Investigations, book 9, chaps. A1-A9, accessed August 15, 2011, at http:// pubs.water.usgs.gov/twri9A/.

Wallace, A., Romney, E.M., Cha, J.W., and Chaudhry, F.M., 1977, Lithium toxicity in plants: Communications in Soil Science and Plant Analysis, v. 8, no. 9, p. 773-780.

Warner, K.L., 2001, Arsenic in glacial drift aquifers and the implication for drinking water-Lower Illinois River Basin: Ground Water, v. 39, no. 3, p. 433-442.

Wind Cave National Park, 2008, Wind Cave history and culture, accessed May 20, 2011, at http://www.nps.gov/wica/ historyculture/index.htm.

Zhu, Wenyi, Young, L.Y., Yee, N., Serfes, M., Rhine, E.D., and Reinfelder, J.R., 2008, Sulfide-driven arsenic mobilization from arsenopyrite and black shale pyrite: Geochimica et Cosmochimica Acta, v. 72, no. 21, p. 5,243-5,250. 



\section{Supplemental Tables}


Table 12. Hydrochemical data for water samples.

$\left[\mathrm{mg} / \mathrm{L}\right.$, milligrams per liter; $\mu \mathrm{S} / \mathrm{cm}$, microsiemens per centimeter at 25 degrees Celsius $\left({ }^{\circ} \mathrm{C}\right)$; $\mu \mathrm{g} / \mathrm{L}$, micrograms per liter; \%, per thousand; $\mathrm{m}$, meters; ; -, no data

\begin{tabular}{|c|c|c|c|c|c|c|c|c|c|c|c|c|c|c|c|c|c|c|c|c|c|c|c|}
\hline \multicolumn{11}{|c|}{ Stream sink sites } & \multicolumn{13}{|c|}{ Stream sink sites } \\
\hline BEVcr & 06402430 & Beaver Creek sink & -- & $04 / 16 / 2007$ & 1800 & -- & 8.1 & 538 & -- & 68.2 & 21.7 & 13.7 & 0.013 & 196 & -- & 236 & 14.3 & 14.8 & 39.7 & 3.7 & -90.10 & -11.92 & -- \\
\hline BEV cr & 06402430 & Beaver Creek sink ${ }^{\mathrm{d}}$ & -- & $06 / 25 / 2008$ & 1120 & -- & 7.8 & 563 & 19.3 & 72.7 & 22.9 & 13.6 & -- & -- & -- & 278 & 25.6 & 16.5 & 65.6 & 4.4 & -- & -- & -- \\
\hline BEVcr & 06402430 & Beaver Creek sink $\mathrm{k}^{\mathrm{d}}$ & -- & 05/22/2009 & 910 & -- & 7.9 & 559 & 11.1 & 77.6 & 26.6 & 13.6 & -- & -- & 263 & 318 & 22.6 & 17.0 & 34.6 & 4.2 & -89.41 & -11.70 & -- \\
\hline HIGHcr & 433745103261900 & Highland Creek sinke & -- & 03/15/2007 & 1230 & 10.4 & 8.8 & 286 & 11.4 & 38.9 & 7.25 & 7.93 & .270 & -- & -- & 149 & 3.06 & 19.2 & 14.5 & 3.3 & -87.60 & -11.95 & - \\
\hline HIGHer & 433745103261900 & Highland Creek sink & -- & 04/26/2007 & 1015 & 10.2 & 9.2 & 288 & 14.8 & 41.3 & 7.46 & 8.24 & .161 & 131 & -- & 146 & 3.01 & 17.4 & 14.6 & 3.0 & -87.70 & -11.90 & -- \\
\hline HIGHcr & 433745103261900 & Highland Creek sinke & -- & 07/09/2007 & 1600 & 2.8 & 8.0 & 315 & 27.2 & 43.7 & 7.80 & 8.97 & .114 & 138 & -- & 163 & 3.04 & 22.4 & 13.7 & 3.9 & -87.10 & -11.78 & -- \\
\hline HIGHcr & 433745103261900 & Highland Creek sink & -- & 09/26/2007 & 1450 & 7.4 & 8.1 & 321 & 15.8 & 42.0 & 7.89 & 8.42 & .111 & 138 & -- & 166 & 2.90 & 19.4 & 15.0 & 2.4 & -88.30 & -11.88 & -- \\
\hline HIGHcr & 433745103261900 & Highland Creek sink & -- & $05 / 14 / 2009$ & 1345 & 9.5 & 9.2 & 280 & 20.4 & 40.1 & 7.63 & 8.39 & -- & -- & 112 & 119 & 4.33 & 13.1 & 14.2 & 3.5 & -87.30 & -11.72 & - \\
\hline \multicolumn{11}{|c|}{ Cave drip sites } & \multicolumn{13}{|c|}{ Cave drip sites } \\
\hline DP1 & 433302103281507 & 6S 5E12DBAB7 & Madison & $04 / 27 / 2007$ & 1400 & 9.5 & 8.3 & 385 & -- & 35.4 & 16.9 & 12.6 & 1.36 & 139 & -- & 167 & 13.2 & 17.6 & 21.3 & 34.2 & -90.90 & -12.42 & -- \\
\hline DP1 & 433302103281507 & 6S 5E12DBAB7 & Madison & 07/29/2009 & 1130 & 12.9 & 7.8 & 348 & -- & 33.8 & 19.0 & 8.27 & -- & -- & 146 & 177 & 7.25 & 16.0 & 22.6 & 32.4 & -90.40 & -12.15 & -- \\
\hline DP2 & 433302103281508 & 6S 5E12DBAB8 & Madison & 04/25/2007 & 1200 & 9.6 & 8.4 & 339 & -- & 45.7 & 13.0 & 4.29 & 1.55 & 157 & -- & 188 & 3.88 & 17.5 & 10.7 & 29.3 & -85.10 & -11.69 & -- \\
\hline DP2 & 433302103281508 & 6S 5E12DBAB8 & Madison & 05/22/2009 & 1515 & -- & -- & 340 & -- & 47.3 & 13.1 & 4.28 & -- & -- & 162 & 195 & 3.60 & 18.2 & 10.6 & 29.3 & -83.90 & -11.54 & -- \\
\hline DP2 & 433302103281508 & 6S 5E12DBAB8 & Madison & 07/29/2009 & 1200 & 12.1 & 7.9 & 255 & -- & 50.1 & 13.3 & 4.40 & -- & -- & 169 & 205 & 3.71 & 17.2 & 10.7 & 25.9 & -82.20 & -11.30 & -- \\
\hline DP3 & 433302103281509 & 6S 5E12DBAB9 & Madison & 04/25/2007 & 1400 & 9.7 & 8.4 & 252 & -- & 37.2 & 8.19 & .97 & .455 & 120 & -- & 144 & 1.27 & 19.3 & 7.44 & 25.2 & -84.40 & -11.61 & -- \\
\hline DP3 & 433302103281509 & 6S 5E12DBAB9 & Madison & 05/22/2009 & 1500 & -- & 7.3 & 255 & -- & 37.7 & 8.06 & .96 & -- & -- & 122 & 149 & 1.10 & 20.0 & 7.08 & 25.0 & -84.00 & -11.57 & -- \\
\hline DP3 & 433302103281509 & 6S 5E12DBAB9 & Madison & 07/29/2009 & 1230 & 9.7 & 8.0 & 349 & -- & 38.2 & 8.04 & .95 & -- & -- & 125 & 151 & 1.17 & 19.0 & 7.79 & 24.3 & -83.70 & -11.54 & -- \\
\hline \multicolumn{11}{|c|}{ Cave water body sites } & \multicolumn{13}{|c|}{ Cave water body sites } \\
\hline PP & 433302103281504 & 6S 5E12DBAB4 & Madison & 04/27/2007 & 1200 & 9.4 & 8.1 & 331 & -- & 34.4 & 19.8 & 4.47 & 0.959 & 157 & -- & 189 & 3.07 & 12.6 & 6.62 & 13.1 & -91.50 & -12.25 & -- \\
\hline $\mathrm{RR}$ & 433302103281506 & 6S 5E12DBAB6 & Madison & 04/18/2007 & 1600 & -- & 7.8 & 435 & 13.8 & 43.2 & 25.1 & 4.86 & 1.29 & 182 & -- & 221 & 2.96 & 13.4 & 6.76 & 12.6 & -90.70 & -12.12 & -- \\
\hline WCL & 433302103281501 & $6 \mathrm{~S} 5 \mathrm{E} 12 \mathrm{DBAB}$ & Madison & 04/18/2007 & 1430 & -- & 8.0 & 335 & 14.8 & 35.7 & 19.4 & 7.67 & 2.38 & 149 & -- & 180 & 4.46 & 13.9 & 9.17 & 16.4 & -90.50 & -12.15 & -- \\
\hline WCL & 433302103281501 & 6S 5E12DBAB & Madison & 07/16/2009 & 1140 & -- & -- & 362 & 14.0 & 35.8 & 19.6 & 7.21 & -- & -- & 162 & 196 & 4.22 & 12.2 & 9.57 & 12.7 & -91.60 & -12.09 & -- \\
\hline WTHL & 433302103281502 & 6S 5E12DBAB2 & Madison & 04/18/2007 & 1230 & -- & 7.8 & 427 & 13.8 & 47.4 & 27.1 & 5.08 & 1.32 & 211 & -- & 255 & 3.02 & 13.2 & 6.91 & 12.8 & -90.10 & -12.11 & -- \\
\hline WTHL & 433302103281502 & 6S 5E12DBAB2 & Madison & $07 / 16 / 2009$ & 1245 & -- & -- & 411 & 12.5 & 43.3 & 24.1 & 4.63 & -- & -- & 199 & 241 & 2.95 & 12.0 & 7.57 & 12.6 & -92.50 & -12.11 & - \\
\hline \multicolumn{11}{|c|}{ Artesian spring sites } & \multicolumn{13}{|c|}{ Artesian spring sites } \\
\hline HBsp & 432703103302801 & 7S 5E10DCBA & Minnelusa $^{f}$ & $03 / 15 / 2007$ & 1000 & 6.8 & 7.3 & 683 & 23.9 & 63.9 & 24.7 & 36.0 & 0.431 & -- & -- & 256 & 45.6 & 18.2 & 69.3 & 6.6 & -113 & -15.05 & -- \\
\hline HBsp & 432703103302801 & 7S 5E10DCBA & Minnelusa ${ }^{2}$ & 04/20/2007 & 1600 & 6.9 & 7.0 & 700 & 24.0 & 64.5 & 25.3 & 36.9 & .417 & 208 & -- & 253 & 45.5 & 18.1 & 67.5 & 7.2 & -113 & -15.07 & -- \\
\hline HBsp & 432703103302801 & 7S 5E10DCBA & Minnelusa $^{\mathrm{f}}$ & 07/09/2007 & 1215 & 5.2 & 7.1 & 718 & 23.9 & 64.6 & 25.5 & 35.6 & .426 & 206 & -- & 251 & 45.8 & 18.9 & 68.7 & 4.7 & -114 & -15.08 & -- \\
\hline HBsp & 432703103302801 & 7S 5E10DCBA & Minnelusa $^{f}$ & 09/27/2007 & 1100 & 7.3 & 7.1 & 672 & 23.9 & 65.4 & 25.4 & 36.8 & .430 & 211 & -- & 256 & 45.0 & 16.8 & 67.8 & 6.3 & -115 & -15.07 & - \\
\hline HBsp & 432703103302801 & 7S 5E10DCBA & Minnelusa ${ }^{f}$ & 05/28/2009 & 1330 & -- & 7.2 & 710 & 23.6 & 69.2 & 25.7 & 37.1 & -- & -- & 217 & 264 & 44.7 & 18.7 & 68.9 & 7.0 & -115 & -15.03 & -- \\
\hline BCsp & 433128103223401 & $6 \mathrm{~S} 6 \mathrm{E} 14 \mathrm{CDB}$ & Madisong $^{g}$ & 03/14/2007 & 1500 & 4.8 & 7.3 & 2,260 & 18.0 & 460 & 76.8 & 29.2 & .409 & -- & -- & 219 & 32.5 & 16.0 & 1,280 & 2.1 & -110 & -14.42 & -- \\
\hline BCsp & 433128103223401 & 6S 6E14CDB & Madisong & 04/17/2007 & 1230 & 6.2 & 7.1 & 2,390 & 19.1 & 443 & 73.3 & 27.4 & .390 & 179 & -- & 217 & 32.9 & 14.9 & 1,290 & 2.1 & -110 & -14.40 & -- \\
\hline BCsp & 433128103223401 & $6 \mathrm{~S} 6 \mathrm{E} 14 \mathrm{CDB}$ & Madisong $^{g}$ & 07/10/2007 & 1145 & -- & 7.0 & -- & 19.4 & 446 & 77.3 & 30.5 & .490 & 177 & -- & 215 & 33.8 & 16.5 & 1,290 & 1.7 & -110 & -14.41 & -- \\
\hline $\mathrm{BCsp}$ & 433128103223401 & $6 \mathrm{~S} 6 \mathrm{E} 14 \mathrm{CDB}$ & Madisong $^{g}$ & 09/26/2007 & 1320 & 5.2 & 6.9 & 2,350 & 18.9 & 478 & 79.4 & 30.8 & .391 & 177 & -- & 215 & 33.1 & 14.3 & 1,280 & 2.0 & -109 & -14.42 & - \\
\hline BCsp & 433128103223401 & $6 \mathrm{~S} 6 \mathrm{E} 14 \mathrm{CDB}$ & Madisong $^{g}$ & 05/28/2009 & 945 & -- & 6.7 & 2,350 & 18.5 & 477 & 78.2 & 29.7 & -- & -- & 186 & 227 & 34.5 & 16.6 & 1,310 & 1.0 & -107 & -14.00 & - \\
\hline CASsp & 432006103330501 & $8 \mathrm{~S} 5 \mathrm{E} 20 \mathrm{CDAB}$ & Madisong $^{g}$ & 06/19/2009 & 1100 & -- & 7.0 & 2,560 & 19.3 & 558 & 83.6 & 27.8 & -- & -- & 190 & 231 & 29.3 & 13.7 & 1,550 & 1.2 & -117 & -15.09 & -- \\
\hline COOsp & 432028103331601 & 8S 5E20BDCB & Madisong $^{g}$ & 06/19/2009 & 1425 & -- & 6.9 & 1,960 & 17.8 & 327 & 75.3 & 30.3 & -- & -- & 193 & 235 & 33.1 & 14.5 & 975 & 2.3 & -116 & -15.01 & -- \\
\hline HSIsp & 432632103285302 & 7S 5E14DDDA & Madisong $^{g}$ & 03/15/2007 & 1100 & 5.0 & 7.3 & 1,020 & 27.2 & 87.5 & 28.0 & 70.0 & .450 & -- & -- & 245 & 97.5 & 23.8 & 167 & 5.8 & -120 & -16.02 & -- \\
\hline HSIsp & 432632103285302 & 7S 5E14DDDA & Madisong $^{\mathrm{g}}$ & 04/17/2007 & 1630 & 5.4 & 7.2 & 1,030 & 27.3 & 89.2 & 29.1 & 71.9 & .456 & 198 & -- & 240 & 99.1 & 22.7 & 168 & 5.7 & -120 & -16.13 & . \\
\hline
\end{tabular}


Table 12. Hydrochemical data for water samples. - Continued

$\left[\mathrm{mg} / \mathrm{L}\right.$, milligrams per liter, $\mu \mathrm{S} / \mathrm{cm}$, microsiemens per centimeter at 25 degrees Celsius $\left({ }^{\circ} \mathrm{C}\right)$; $\mu \mathrm{L} / \mathrm{L}$, micrograms per liter, \%o, per thousand; $\mathrm{m}$, meters; - -, no data

or not applicable]

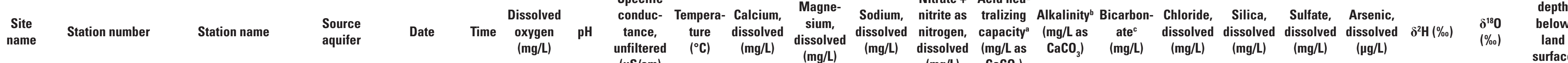

Nitrate + Acid neu-

nitrite as tralizing Alkalinity Bicarbon- Chloride, Silica, Sulfate, Arsenic, $\quad \begin{array}{r}\text { Well } \\ \text { depth }\end{array}$

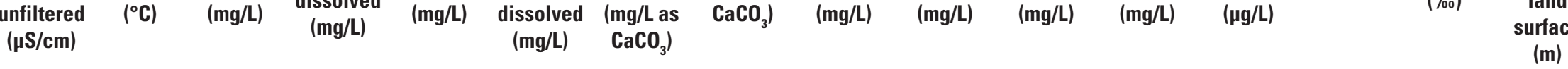

\begin{tabular}{|c|c|c|c|c|c|c|c|c|c|c|c|c|c|c|c|c|c|c|c|c|c|c|c|}
\hline \multicolumn{11}{|c|}{ Artesian spring sites-Continued } & \multicolumn{13}{|c|}{ Artesian spring sites-Continued } \\
\hline HSIsp & 432632103285302 & 7S 5E14DDDA & Madison $^{g}$ & 07/09/2007 & 1350 & 5.7 & 7.0 & 1,040 & 27.6 & 92.2 & 29.3 & 71.2 & 0.487 & 198 & -- & 241 & 99.3 & 24.4 & 170 & 3.5 & -120 & -15.97 & -- \\
\hline HSIsp & 432632103285302 & 7S 5E14DDDA & Madison $^{g}$ & 09/27/2007 & 1320 & 5.5 & 6.8 & 1,050 & 27.6 & 94.1 & 30.1 & 74.4 & .489 & 204 & -- & 248 & 94.0 & 21.9 & 174 & 5.8 & -122 & -15.91 & -- \\
\hline HSIsp & 432632103285302 & 7S 5E14DDDA & Madison $^{g}$ & $05 / 21 / 2009$ & 1600 & 7.1 & 7.2 & 1,030 & 27.4 & 96.2 & 30.1 & 70.2 & -- & -- & 206 & 251 & 96.4 & 25.0 & 187 & 6.3 & -123 & -15.88 & -- \\
\hline KIDsp & 432605103285401 & 7S 5E14DDD & Madison $^{g}$ & 06/19/2009 & 1630 & -- & 7.0 & 1,580 & 27.8 & 182 & 38.9 & 81.8 & -- & -- & 180 & 219 & 117 & 22.4 & 478 & 3.5 & -125 & -16.31 & -- \\
\hline MNKsp & 432605103290901 & 7S 5E14D & Madison $^{g}$ & $05 / 28 / 2009$ & 1450 & -- & 6.7 & 1,300 & 32.4 & 123 & 32.9 & 90.8 & -- & -- & 195 & 238 & 125 & 27.4 & 275 & 5.2 & -127 & -16.44 & -- \\
\hline BRsp & 433525103224401 & $5 \mathrm{~S} 6 \mathrm{E} 26 \mathrm{BBCD}$ & Unknown $^{\mathrm{h}}$ & 08/13/2009 & 1545 & 4.5 & 7.2 & 2,900 & 29.6 & 594 & 149 & 16.9 & -- & -- & 134 & 163 & 3.21 & 13.8 & 1,940 & 2.2 & -86.60 & -11.11 & -- \\
\hline CBsp & 432744103293401 & $7 \mathrm{~S} 5 \mathrm{E} 11 \mathrm{BAAB}$ & Unknown ${ }^{\mathrm{h}}$ & $08 / 21 / 2009$ & 1445 & 9.1 & 7.0 & 1,130 & 14.6 & 168 & 49.2 & 15.1 & -- & -- & 235 & 286 & 19.6 & 12.8 & 388 & 5.6 & -101 & -13.28 & -- \\
\hline SWsp & 432849103283201 & 6S 5E36CDBB & Unknown ${ }^{\mathrm{h}}$ & $06 / 17 / 2010$ & 1600 & 11.8 & 7.4 & 2,500 & 15.7 & 502 & 107 & 6.78 & -- & -- & 172 & 209 & 5.09 & 8.49 & 1,540 & 1.1 & -90.80 & -11.83 & - \\
\hline \multicolumn{11}{|c|}{ Shallow spring sites } & \multicolumn{13}{|c|}{ Shallow spring sites } \\
\hline BRNsp & 433137103342101 & 6S 5E18CABD & Minnelusa $^{f}$ & $06 / 11 / 2010$ & 1020 & 13.8 & 7.1 & 568 & 10.4 & 59.0 & 42.2 & 5.88 & -- & -- & 295 & 359 & 3.64 & 11.4 & 20.5 & 16.9 & -97.70 & -12.73 & -- \\
\hline EMsp & 433332103291801 & 6S 5E 2ACBD & Minnelusa $^{f}$ & 08/13/2009 & 915 & 6.8 & 7.4 & 656 & 12.7 & 47.9 & 61.8 & 3.10 & -- & -- & 358 & 436 & 2.04 & 11.2 & 20.4 & 15.3 & -95.60 & -12.48 & -- \\
\hline HSsp & 433258103270801 & 6S 6E 7BAAC & Minnelusa $^{f}$ & 08/13/2009 & 1100 & 4.9 & 7.1 & 575 & 14.8 & 72.8 & 11.8 & 3.98 & -- & -- & 221 & 270 & 3.59 & 14.1 & 9.80 & 19.5 & -95.90 & -12.63 & -- \\
\hline NCsp & 433312103264701 & 6S 6E 6DCAA & Minnelusa $^{f}$ & 08/13/2009 & 1015 & 7.7 & 7.2 & 409 & 12.8 & 75.0 & 6.50 & 2.88 & -- & -- & 210 & 256 & 2.40 & 12.3 & 7.12 & 16.9 & -95.60 & -12.55 & -- \\
\hline WCsp & 433056103322201 & 6S 5E21BCBC & Minnelusa $^{f}$ & 08/21/2009 & 945 & 1.5 & 7.1 & 689 & 15.0 & 67.8 & 53.9 & 5.27 & -- & -- & 385 & 469 & 3.84 & 13.9 & 19.5 & 12.0 & -95.20 & -12.40 & -- \\
\hline WITsp & 433611103335801 & 5S 4E35DDBC & Minnelusa $^{f}$ & 08/22/2009 & 1230 & 10.4 & 7.2 & 528 & 11.6 & 55.4 & 23.4 & 10.2 & -- & -- & 223 & 272 & 5.30 & 8.71 & 24.4 & 4.5 & -90.90 & -11.62 & -- \\
\hline IRIsp & 434249103370401 & 4S 4E11CCBB & Precambrian & $06 / 17 / 2010$ & 1420 & 10.9 & 6.7 & 508 & 14.7 & 46.9 & 12.6 & 13.8 & -- & -- & 156 & 190 & 10.5 & 21.2 & 19.2 & 2.7 & -90.70 & -12.06 & -- \\
\hline RGPsp & 433551103291901 & 5S 5E23DBCD & Precambrian & 08/13/2009 & 1300 & 7.0 & 6.5 & 372 & 9.1 & 55.3 & 11.9 & 6.67 & -- & -- & 182 & 222 & 1.93 & 17.1 & 19.7 & 2.0 & -89.50 & -12.16 & -- \\
\hline SLsp & 434020103350101 & 4S 4E25DB & Precambrian & $03 / 17 / 2010$ & 1135 & 7.6 & 6.5 & 319 & 2.1 & 44.8 & 8.47 & 5.62 & -- & -- & 123 & 150 & 3.14 & 17.3 & 26.7 & .82 & -112 & -14.91 & -- \\
\hline PARsp & 433717103235401 & $5 \mathrm{~S} 6 \mathrm{E} 15 \mathrm{BBAC}$ & White River & $08 / 13 / 2009$ & 1415 & .8 & 7.2 & 607 & 32.4 & 61.8 & 18.4 & 11.5 & -- & -- & 258 & 314 & 5.15 & 21.0 & 8.38 & 11.1 & -87.80 & -11.10 & -- \\
\hline \multicolumn{11}{|c|}{ Well sites } & \multicolumn{13}{|c|}{ Well sites } \\
\hline BOW & 432555103323201 & 7S 5E20AACA & $\begin{array}{l}\text { Minnelusa } \\
\end{array}$ & $05 / 15 / 2009$ & 1500 & 4.6 & 7.3 & 890 & 22.7 & 99.8 & 33.9 & 39.1 & -- & -- & 208 & 253 & 48.6 & 18.1 & 198 & 3.3 & -117 & -15.28 & 152 \\
\hline COL & 432727103390201 & 7S 4E 9BACA & Minnelusa & 05/07/2009 & 1200 & 6.1 & 7.2 & 760 & 7.9 & 99.2 & 41.5 & 6.49 & -- & -- & 224 & 272 & 2.83 & 11.1 & 201 & 4.5 & -101 & -13.08 & 177 \\
\hline CRA & 432846103280501 & $6 \mathrm{~S} 5 \mathrm{E} 36 \mathrm{DCBC}$ & Minnelusa & 05/14/2009 & 1615 & 8.6 & 7.4 & 809 & 12.8 & 101 & 46.9 & 9.76 & -- & -- & 172 & 210 & 2.67 & 9.02 & 276 & 10.1 & -93.20 & -12.27 & 113 \\
\hline FER & 432437103305701 & 7S 5E27CCCD & Minnelusa & 05/08/2009 & 1325 & 9.2 & 7.7 & 1,100 & 32.9 & 97.5 & 29.4 & 86.6 & -- & -- & 185 & 224 & 123 & 27.5 & 207 & 5.6 & -126 & -16.26 & 107 \\
\hline FRA & 432958103281401 & 6S 5E24CAAB & Minnelusa & 05/08/2009 & 1535 & 6.3 & 7.9 & 434 & 10.7 & 47.2 & 21.3 & 15.1 & -- & -- & 200 & 242 & 3.32 & 9.00 & 32.9 & 37.1 & -91.80 & -12.08 & 128 \\
\hline HAL & 432720103303701 & 7S 5E15BABB & Minnelusa & 05/08/2009 & 925 & 5.6 & 7.5 & 985 & 14.1 & 112 & 38.5 & 46.1 & -- & -- & 243 & 295 & 67.3 & 14.4 & 210 & 4.0 & -118 & -15.40 & 43 \\
\hline HUN & 433034103284701 & 6S 5E23DBBB & Minnelusa & 03/14/2007 & 1100 & 7.3 & 7.5 & 400 & 15.1 & 48.2 & 17.1 & 9.57 & 0.589 & -- & -- & 235 & 5.88 & 15.5 & 17.3 & 7.9 & -90.40 & -12.17 & 250 \\
\hline HUN & 433034103284701 & 6S 5E23DBBB & Minnelusa & $04 / 17 / 2007$ & 940 & -- & 7.3 & 419 & 15.3 & 50.5 & 18.1 & 10.1 & .608 & 190 & -- & 230 & 5.97 & 15.4 & 17.2 & 7.7 & -92.40 & -12.23 & 250 \\
\hline HUN & 433034103284701 & 6S 5E23DBBB & Minnelusa & 09/27/2007 & 930 & 8.0 & 7.2 & 409 & 15.5 & 51.0 & 17.6 & 10.0 & .596 & 192 & -- & 233 & 5.75 & 15.0 & 17.0 & 7.4 & -91.10 & -12.21 & 250 \\
\hline HUN & 433034103284701 & 6S 5E23DBBB & Minnelusa & $05 / 21 / 2009$ & 1510 & 7.6 & 7.3 & 414 & 13.9 & 51.1 & 17.9 & 9.32 & -- & -- & 198 & 242 & 5.77 & 15.2 & 17.9 & 6.6 & -92.20 & -12.18 & 250 \\
\hline INM & 432332103314801 & 7S 5E33ABDD & Minnelusa & 05/07/2009 & 1500 & 6.3 & 7.4 & 1,190 & 20.3 & 110 & 37.9 & 83.1 & -- & -- & 209 & 255 & 119 & 23.9 & 247 & 4.4 & -125 & -16.22 & 147 \\
\hline KIR2 & 433420103374901 & $5 \mathrm{~S} 4 \mathrm{E} 34 \mathrm{BDDB}$ & Minnelusa & $06 / 11 / 2010$ & 1340 & 9.3 & 7.2 & 771 & 8.3 & 107 & 30.9 & 13.4 & -- & -- & 318 & 387 & 41.1 & 12.9 & 24.1 & 3.0 & -97.00 & -12.83 & 5 \\
\hline LEF & 433215103464401 & 6S 3E 5CCD & Minnelusa & 05/14/2009 & 1110 & 6.5 & 7.5 & 467 & 13.2 & 48.0 & 26.1 & 9.70 & -- & -- & 224 & 272 & 3.31 & 11.9 & 21.5 & 6.5 & -106 & -13.81 & 235 \\
\hline MEY & 433215103365801 & $6 \mathrm{~S} 4 \mathrm{E} 11 \mathrm{CCDB}$ & Minnelusa & $06 / 11 / 2010$ & 1510 & 39.0 & 7.4 & 495 & 10.5 & 55.8 & 30.9 & 6.69 & -- & -- & 223 & 271 & 9.31 & 13.4 & 29.0 & 18.5 & -99.30 & -12.88 & 104 \\
\hline MILN & 432806103330801 & 8S 5E 5CADD & Minnelusa & 05/07/2009 & 1650 & 4.8 & 7.0 & 1,490 & 23.1 & 179 & 52.6 & 75.1 & -- & -- & 242 & 295 & 99.2 & 24.0 & 433 & 3.2 & -122 & -15.91 & 152 \\
\hline MYR & 433003103420701 & $7 \mathrm{~S} 3 \mathrm{E} 36 \mathrm{CBCC}$ & Minnelusa & 05/08/2009 & 1110 & 12.0 & 7.5 & 444 & 11.2 & 59.0 & 20.2 & 5.27 & -- & -- & 225 & 274 & 2.79 & 12.7 & 13.5 & 24.6 & -109 & -14.14 & 85 \\
\hline PAL & 432806103284101 & $7 \mathrm{~S} 5 \mathrm{E} 1 \mathrm{CBCC}$ & Minnelusa & 05/15/2009 & 1600 & 7.6 & 7.0 & 582 & 13.1 & 62.4 & 29.6 & 13.1 & -- & -- & 222 & 270 & 15.9 & 10.3 & 61.4 & 10.6 & -109 & -14.30 & 168 \\
\hline PEK & 432852103264401 & $6 \mathrm{~S} 6 \mathrm{E} 31 \mathrm{DBDA}$ & Minnelusa & $05 / 21 / 2009$ & 1410 & 10.1 & 7.0 & 786 & 13.8 & 90.6 & 37.8 & 19.5 & -- & -- & 203 & 248 & 16.0 & 12.5 & 198 & 6.1 & -107 & -14.16 & 187 \\
\hline WIL & 433141103390901 & 6S 4E16CABB & Minnelusa & $06 / 25 / 2010$ & 1030 & 10.5 & 7.2 & 479 & 11.8 & 53.0 & 29.8 & 8.07 & -- & -- & 220 & 268 & 7.14 & 14.0 & 22.7 & 18.7 & -104 & -13.32 & 129 \\
\hline
\end{tabular}


Table 12. Hydrochemical data for water samples. - Continued

$\left[\mathrm{mg} / \mathrm{L}\right.$, milligrams per liter, $\mu \mathrm{S} / \mathrm{cm}$, microsiemens per centimeter at 25 degrees Celsius $\left({ }^{\circ} \mathrm{C}\right)$; $\mu \mathrm{g} / \mathrm{L}$, micrograms per liter; \%o, per thousand; $\mathrm{m}$, meters; ; -, no data

or not applicable]

Site
name $\quad$ Station number $\quad$ Station name $\quad \begin{aligned} & \text { Source } \\ & \text { aquifer }\end{aligned} \quad$ Date $\quad$ Time $\underset{\substack{\text { Dissolved } \\(\mathrm{mg} / \mathrm{L} / \mathrm{L})}}{\mathrm{pH}}$

Specific Nitrate + Acid neu-

nitrite as tralizing Alkalinity Bicarbon- Chloride, Silica, Sulfate, Arsenic, $\quad \begin{array}{r}\text { Well } \\ \text { depth }\end{array}$

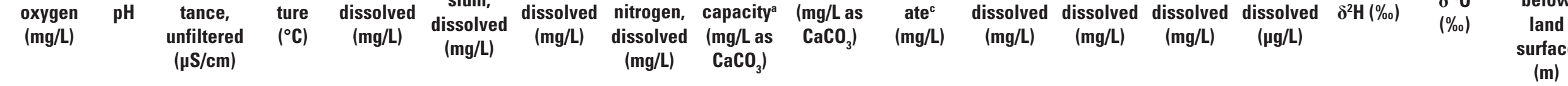

\begin{tabular}{|c|c|c|c|c|c|c|c|c|c|c|c|c|c|c|c|c|c|c|c|c|c|c|c|}
\hline \multicolumn{11}{|c|}{ Well sites-Continued } & \multicolumn{13}{|c|}{ Well sites-Continued } \\
\hline BOG & 432858103334201 & 6S 5E31DAAC & Madison & $04 / 26 / 2007$ & 1730 & 8.4 & 7.8 & 466 & 15.2 & 44.7 & 29.9 & 6.29 & 1.29 & 217 & -- & 262 & 2.63 & 12.7 & 10.5 & 15.8 & -99.00 & -12.90 & 201 \\
\hline BOG & 432858103334201 & 6S 5E31DAAC & Madison & $07 / 15 / 2009$ & 1415 & -- & 7.5 & 444 & 16.0 & 41.3 & 29.1 & 6.39 & -- & -- & 216 & 263 & 2.24 & 11.8 & 10.0 & 10.2 & -97.20 & -12.69 & 201 \\
\hline CON & 433326103352001 & 6S 4E 1DBBB & Madison & $04 / 23 / 2007$ & 1200 & 8.6 & 7.7 & 579 & 8.7 & 65.4 & 29.9 & 10.8 & 2.24 & 240 & -- & 292 & 8.10 & 12.6 & 28.9 & 6.4 & -98.60 & -12.86 & 30 \\
\hline $\mathrm{CON}$ & 433326103352001 & 6S 4E 1DBBB & Madison & 07/15/2009 & 940 & -- & 7.2 & 753 & 12.5 & 86.3 & 37.0 & 14.3 & -- & -- & 316 & 385 & 17.5 & 13.0 & 34.3 & 3.6 & -100 & -13.02 & 30 \\
\hline KAI & 433114103281601 & 6S 5E24BAAA & Madison & 07/09/2007 & 1000 & 6.8 & 7.1 & 435 & 15.2 & 51.4 & 18.5 & 9.74 & .616 & 188 & -- & 229 & 5.74 & 16.3 & 16.4 & 6.8 & -90.10 & -12.24 & 238 \\
\hline KAI & 433114103281601 & 6S 5E24BAAA & Madison & 09/26/2007 & 1000 & 8.4 & 7.1 & 413 & 15.1 & 50.8 & 18.4 & 9.86 & .626 & 188 & -- & 228 & 5.52 & 14.9 & 16.4 & 7.1 & -91.60 & -12.24 & 238 \\
\hline Md7-11 & 433115103251401 & $\begin{array}{c}\text { 6S 6E21BBBB } \\
\text { (CU91A) }\end{array}$ & Madison & 04/20/2007 & 1150 & 4.0 & 7.3 & 403 & 13.4 & 40.4 & 19.6 & 16.4 & .310 & 170 & -- & 206 & 5.95 & 12.8 & 23.5 & .28 & -89.70 & -11.98 & 355 \\
\hline MIL & 432340103421501 & $7 \mathrm{~S} 3 \mathrm{E} 36 \mathrm{CBDC}$ & Madison & $04 / 23 / 2007$ & 1430 & 3.9 & 7.3 & 743 & 21.5 & 77.8 & 26.6 & 37.5 & .112 & 212 & -- & 257 & 48.0 & 22.1 & 110 & .99 & -125 & -16.64 & 651 \\
\hline MIL & 432340103421501 & $7 \mathrm{~S} 3 \mathrm{E} 36 \mathrm{CBDC}$ & Madison & $03 / 17 / 2010$ & 1500 & 8.3 & 7.1 & 730 & -- & 81.0 & 26.6 & 36.7 & -- & -- & 213 & 259 & 48.4 & 24.3 & 98.3 & .47 & -128 & -16.54 & 651 \\
\hline PW1 & 433311103263101 & $6 \mathrm{~S} 6 \mathrm{E} 6 \mathrm{DDAB}$ & Madison & $05 / 24 / 2007$ & 1230 & 7.5 & 7.3 & 385 & 13.8 & 46.2 & 15.9 & 12.8 & .569 & 178 & -- & 217 & 5.10 & 16.1 & 17.9 & 8.5 & -89.90 & -12.01 & 242 \\
\hline PW1 & 433311103263101 & $6 \mathrm{~S} 6 \mathrm{E} 6 \mathrm{DDAB}$ & Madison & 07/29/2009 & 1245 & 13.7 & 7.5 & 384 & 14.7 & 46.1 & 15.2 & 12.2 & -- & -- & 185 & 225 & 5.33 & 16.0 & 18.3 & 8.8 & -90.00 & -11.94 & 242 \\
\hline PW2 & 433311103263102 & 6S 6E 6DDAA & Madison & $05 / 24 / 2007$ & 1330 & 3.9 & 7.7 & 586 & 14.9 & 24.3 & 13.5 & 91.8 & .210 & 223 & -- & 270 & 20.2 & 11.1 & 43.8 & 26.7 & -87.10 & -11.88 & 209 \\
\hline PW2 & 433311103263102 & 6S 6E 6DDAA & Madison & 07/29/2009 & 920 & 7.4 & 7.8 & 543 & 14.5 & 27.3 & 13.7 & 78.5 & -- & -- & 223 & 271 & 17.4 & 11.5 & 38.4 & 23.0 & -88.30 & -11.83 & 209 \\
\hline STR & 433150103230501 & 6S 6E15ABDD & Madison & $03 / 14 / 2007$ & 1400 & 6.7 & 7.7 & 327 & 12.8 & 39.0 & 13.8 & 9.08 & .511 & -- & -- & 189 & 2.48 & 16.3 & 11.2 & 8.9 & -89.30 & -11.86 & 286 \\
\hline STR & 433150103230501 & 6S 6E15ABDD & Madison & $04 / 17 / 2007$ & 1430 & 7.4 & 7.5 & 343 & 20.0 & 39.8 & 14.1 & 9.32 & .520 & 157 & -- & 190 & 2.55 & 16.4 & 11.0 & 8.5 & -88.20 & -11.87 & 286 \\
\hline STR & 433150103230501 & 6S 6E15ABDD & Madison & 07/10/2007 & 925 & -- & 7.3 & 356 & 23.1 & 40.5 & 14.4 & 9.31 & .516 & 142 & -- & 172 & 2.56 & 17.2 & 10.9 & 7.6 & -88.50 & -11.84 & 286 \\
\hline STR & 433150103230501 & 6S 6E15ABDD & Madison & 09/26/2007 & 1130 & .5 & 6.8 & 342 & 16.7 & 40.0 & 14.1 & 9.38 & .513 & 158 & -- & 192 & 2.47 & 15.8 & 11.3 & 8.9 & -87.10 & -11.82 & 286 \\
\hline STR & 433150103230501 & 6S 6E15ABDD & Madison & $05 / 22 / 2009$ & 1045 & -- & 7.6 & 330 & 19.2 & 40.3 & 14.3 & 9.01 & -- & -- & 166 & 201 & 2.57 & 17.0 & 11.4 & 9.5 & -88.30 & -11.82 & 286 \\
\hline SVE & 432825103391201 & $7 \mathrm{~S} 4 \mathrm{E} 4 \mathrm{BACA}$ & Madison & $04 / 23 / 2007$ & 1800 & 8.4 & 7.7 & 455 & 12.1 & 53.0 & 26.8 & 4.67 & .451 & 231 & -- & 281 & 1.86 & 12.6 & 8.61 & 3.9 & -114 & -15.14 & 269 \\
\hline SVE & 432825103391201 & 7S 4E 4BACA & Madison & $06 / 26 / 2008$ & 1305 & -- & 6.5 & 452 & 16.6 & 50.9 & 25.6 & 4.33 & -- & -- & -- & 288 & 1.82 & 11.6 & 8.81 & -- & -- & -- & 269 \\
\hline SVE & 432825103391201 & 7S 4E 4BACA & Madison & 09/02/2009 & 1000 & 8.7 & 7.2 & 453 & 18.1 & 51.9 & 26.2 & 4.43 & -- & -- & 241 & 294 & 1.93 & 12.0 & 9.11 & 3.9 & -116 & -15.16 & 269 \\
\hline DUR & 433658103332301 & $5 \mathrm{~S} 5 \mathrm{E} 17 \mathrm{BCDB}$ & Precambrian & $06 / 17 / 2010$ & 1145 & 8.0 & 6.7 & 299 & 14.5 & 43.1 & 7.63 & 6.66 & -- & -- & 130 & 158 & 3.82 & 22.9 & 14.4 & 5.7 & -87.80 & -12.00 & 85 \\
\hline GRE & 433701103323401 & $5 \mathrm{~S} 5 \mathrm{E} 17 \mathrm{ACDD}$ & Precambrian & $06 / 17 / 2010$ & 1325 & 9.5 & 7.0 & 564 & 11.3 & 75.9 & 18.2 & 17.7 & -- & -- & 208 & 253 & 28.8 & 19.7 & 36.7 & 2.6 & -92.70 & -12.38 & 32 \\
\hline KIR1 & 433821103360901 & 5S 4E 2DDBD & Precambrian & 06/17/2010 & 1020 & 7.8 & 6.9 & 718 & 7.1 & 88.3 & 24.0 & 24.8 & -- & -- & 252 & 307 & 53.8 & 19.3 & 40.6 & 1.8 & -97.80 & -12.84 & 8 \\
\hline MOR & 433635103354301 & 5S 4E $13 \mathrm{CCAC}$ & Precambrian & $06 / 25 / 2010$ & 1200 & 8.8 & 7.0 & 774 & 11.3 & 47.3 & 78.2 & 14.1 & -- & -- & 424 & 517 & 8.07 & 18.8 & 22.1 & 35.2 & -91.80 & -11.95 & 82 \\
\hline SZE & 433718103333101 & 5S 5E17BBBA & Precambrian & 06/03/2010 & 1455 & 9.3 & 7.0 & 523 & 12.2 & 77.0 & 15.9 & 11.7 & -- & -- & 217 & 265 & 15.1 & 19.4 & 40.5 & 1.9 & -94.20 & -12.63 & 38 \\
\hline WOO & 433636103343901 & 5S 5E $18 \mathrm{CCAC}$ & Precambrian & $06 / 11 / 2010$ & 1215 & 10.2 & 6.5 & 196 & 9.1 & 24.8 & 7.14 & 5.00 & -- & -- & 62 & 76 & 4.57 & 17.3 & 27.1 & 12.7 & -87.40 & -11.99 & 17 \\
\hline
\end{tabular}

"Water, unfiltered, inflection-point titration method (incremental titration method). field, milligrams per liter as calcium cato

${ }^{6}$ Water, filtered, fixed endpoint $(\mathrm{pH} 4.5)$ titration, laboratory, milligrams per liter as calcium carbonate.

Calculated from alkalinity by method of Eaton and others (1995).

Beaver Creek near Pringle, South Dakota, station 06402430.

"Highland Creek above Madison outcrop, station 434249103370401.

Assumed to flow primarily from Minnelusa aquifer but could include water from other aquifers.

h Possibly artesian flowing from Madison or Minnelusa aquifer or both 
Table 13. Summary of hydrochemical data for the five hydrogeologic domains.

$\left[\mathrm{PC}\right.$, Precambrain aquifer; SD, standard deviation; $\mathrm{mg} / \mathrm{L}$, milligrams per liter; $\mu \mathrm{S} / \mathrm{cm}$, microsiemens per centimeter at 25 degrees Celsius $\left({ }^{\circ} \mathrm{C}\right) ; \mu \mathrm{g} / \mathrm{L}$, micrograms per liter; \%, per thousand; m, meters; --, no data or not applicable]

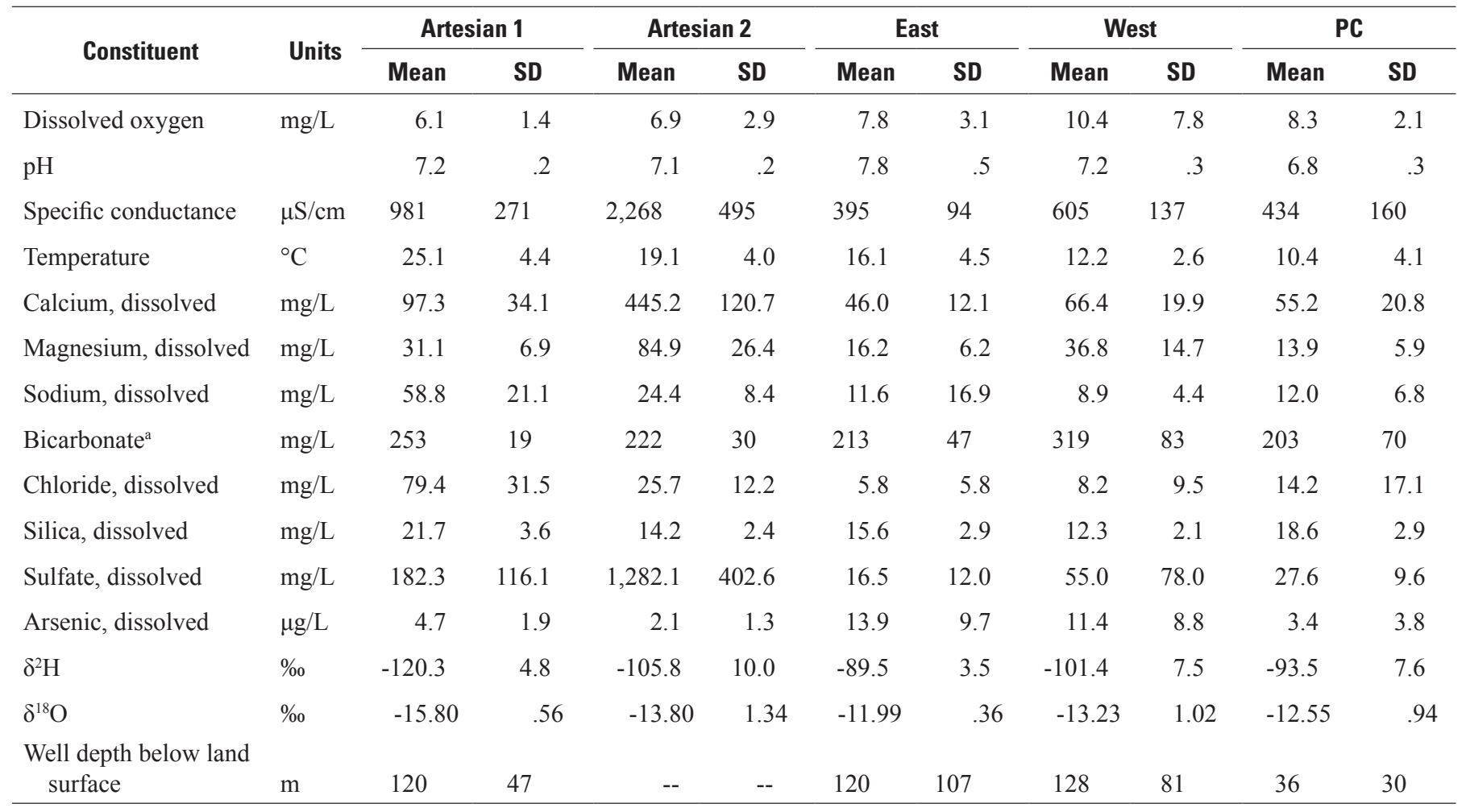

${ }^{a}$ Calculated from alkalinity method of Eaton and others (1995).

Publishing support provided by:

Rolla Publishing Service Center

For additional information concerning this publication, contact:

Director, USGS South Dakota Water Science Center

1608 Mt. View Rd.

Rapid City, SD 57702

(605) 394-3200

Or visit the South Dakota Water Science Center Web site at:

http://sd.water.usgs.gov 



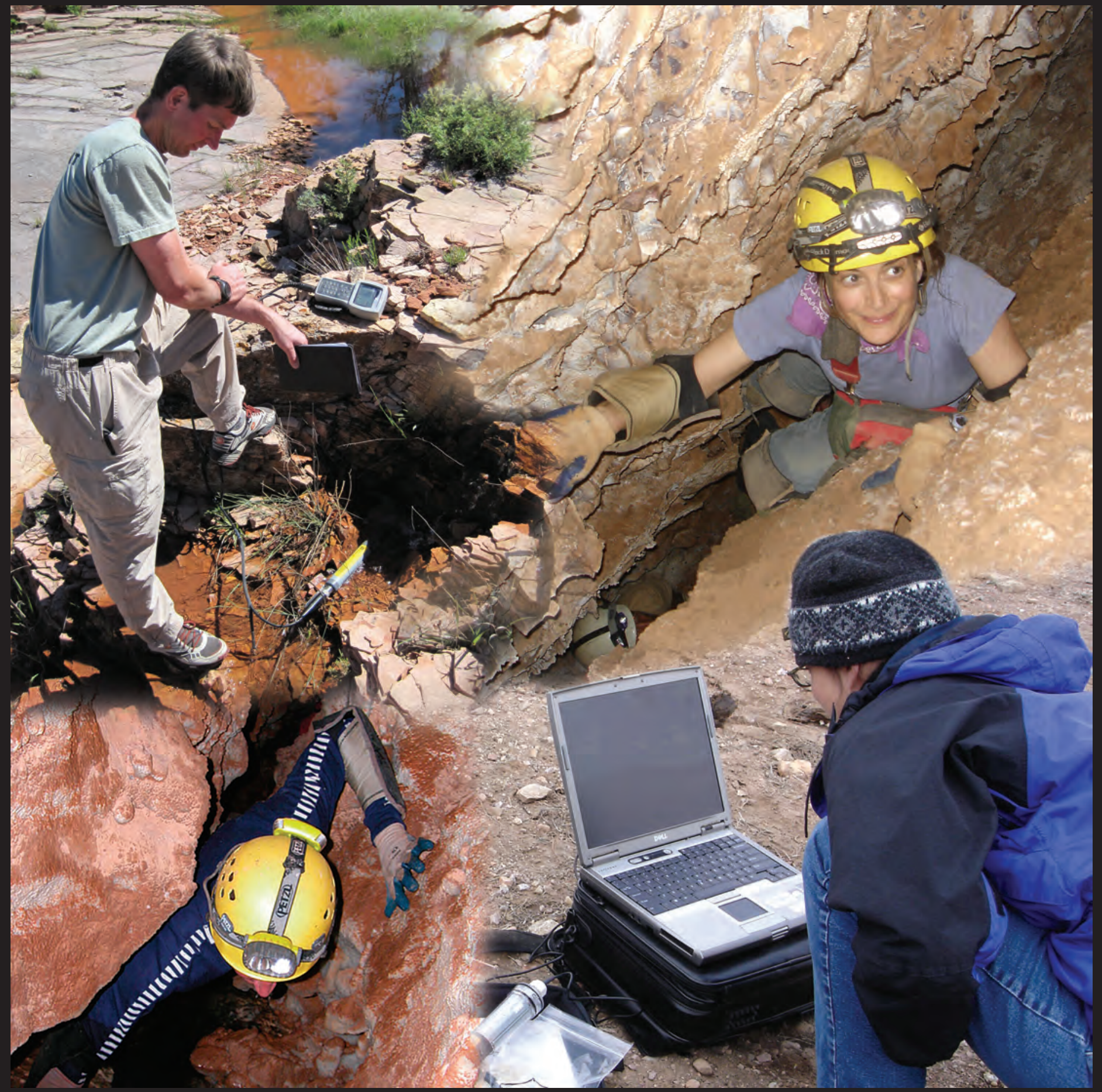

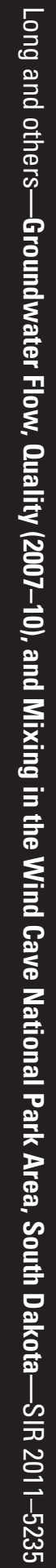

